\title{
乳嘴蜂窠ノ遺傳的關係二就テノ研究
}

\author{
第一編 乳嘴蜂菒遺傳卜双生兒 \\ Morio Okasaki : Über die Bedeutung der Erbfaktoren bei der Pneumatisa der \\ Warzenfortsātze. (Erste Mitteilung: $Z$ willingsforschung)

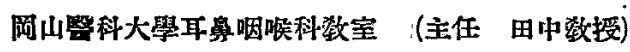 \\ 講皈醫學士岡崎 衞 生 \\ 本論文ノ大要八第 38 回 ${ }^{(58)}$ 及ビ第 39 回 ${ }^{(59)}$ 大日本耳鼻咽喉科會總會二於デ \\ 演述シタルモノナルガ. 其後更二材料习加へ研究フ僬メタルモノナリ。
}

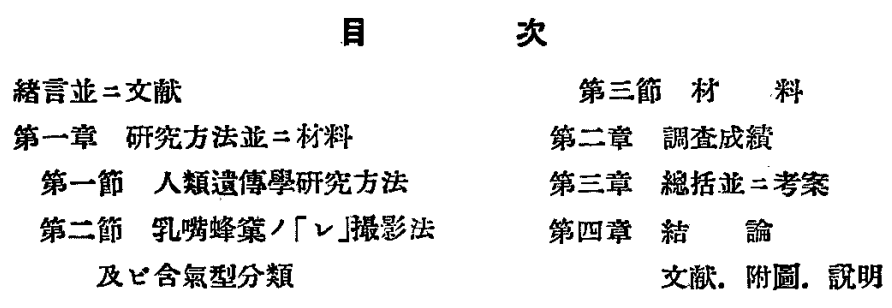

緒言並二文献

乳嘴䗋案 萬態ニシテ. 其良好ナル發澾ト完全ナル缺如ト ノ兩極端間 ニハアラュル移行型 7 包含ス。近時 Wittmaack ${ }^{(108)}$ 八乳嘴䗋菓型り種々相八中耳被

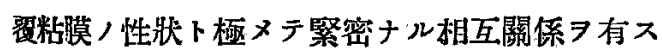
ルモノナル事フ闇明シ。之ヨ中耳體質卜命名シ テ中耳炎，經過及ビ轉歸二對シ最モ重大ナル影 響ヲ及ボスモノナリト提唱シ。識者ノ注意习新 ニセり。郎チ總べテ重症ノ中耳炎八所謂病的蜂 策從ツテ多少二拘ラズ肥厚七ル中耳粘膜

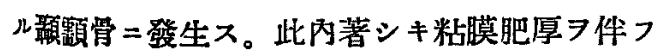
高度/含氣障碍八，從來考へラレシガ如ク慢性 炎症 $=ヨ ル$ 骨象牙質化
テ，實二慢性耳炎，素地トナルモノナリ。又急 性耳炎八輕度乃至中等度, 会氮障碍㩒言七バ發 育八檄亦可良ナルモ細胞間壁厚ク排列不規則ナ ルヨ特異トスル蜂策及ビ夫レニ相當スル性狀， 粘膜二好發ス。而シテ此際病的䗋荣二於テ八局 所解剖的關係不良ニシテ且ツ粘膜，抵抗娍弱七 ルノ そナラズ腅膜 =直接連絡スル胎生期血管系 ノ殘存スルコトアル第メ一度耳炎二侵サル、 ヤ. 例一適時適切ナル療法ア護ズルト踓モ. 或 八經過遷延シテ萑䓦治瘾七ズ，或八念激ナル經 過ノ下=乳嘴突起炎二移行シ. 將又. 恐ル可キ 頭蓋內合㴊症 ルコトアリ。之二反シ健常ナル中耳粘膜二被覆 
サル、所謂正常䗋巢二於テハ例人羅患スルトモ 順調ニ治瘾スルラ常トストイフ。但シ遺憾乍ラ 正常䗋菑习有スル個人ハ比較的傼少ナリ。氏， 所論八此點=關スル限リ ハ Albrecht(1925)(2), Steurer $(1925,1926)^{(87.88)}$, Beck, J. $(1926)^{(15)}$, Hanse $(1930)^{(29)}$, 戔江( $(1932)^{(116)}$, 山下 $(1932)^{(110)}$

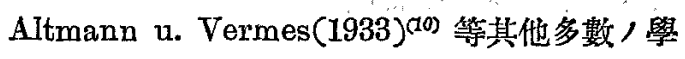
者ニヨり立證補遗サン今ヤー人定說タラントス ノシナラズ Lange, W.(1933)(43), Rollin(1933) (6)等=從へバ. 彼 「ムローズス」耳炎=於テ スラ其㿥後フ支配スル最終因子八實二乳嘴䗋巢 潔造，個人的差異二存スルトイフ，以テ乳嘴蜂 巢ノ耳炎二對スル意挛ノ如何二重要ナルカラ籍 フニ足ラン。而シテ吾人ハ一ガ二於テ輓近ノ進 步セル「レントゲン」裝置ト適切ナル撮影方法

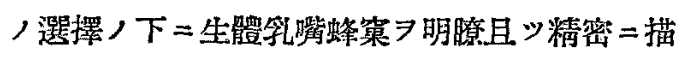
寫シ得ルガ故二逆二乳嘴䗋菒ノ爿態 $コ$ 所謂中 耳顝質 7 制定シ. 以テ中耳炎ノ經過及ビ踩後 7 推测シ更 $=$ 治源方針 7 決定スル等. 臨牀上二資 シ得儿所尠っラズ。然ル二此䗋菓系種々相)發 生本䯤ハ未ダ明カナラズシテ，遗傳的要䄪二重 キヨ置ク說ト尃ラ外因二因リ支配サル、ト，見

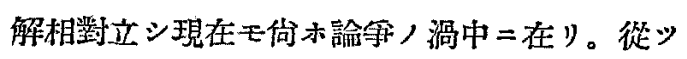
テ之ガ新レノ要約ニヨリ規定サル、モノナルカ ヨ解沈スルコトハ. 耳科學二於テ最モ興味厂ル 間題ノーナリト云フ可シ。

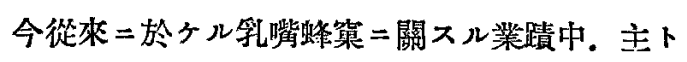
シテ蜂巢系ニ於ケ几個人的差異二注目シ. 或八 更二其發生本態二論及七ル研究 7 回㕍頁セン =次 ノ如シ。

乳嘴䗋荤研究，沿革八. 遠ク 16 世紀，中葉= 溯り恐ラクVesalius ${ }^{(102)}$ ヨ以ラ简矢トス。サレ ド其挠久シキ二亘り研究八補德或八急激ナル氮

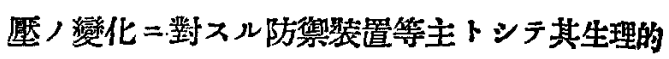
方面二限局サレシ篇メ. 其解剖的構造二就テ， 知見以㱠ンド何等補遺サ心、所無ク徒ラニ先人 既踏ノ跡习辿りシカノ如キ觀 科學ノ基礎未ダ緒二就カス． 從ツテ乳嘴蜂笨

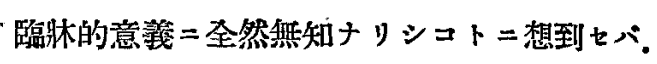
之ガ單二系統解剖學ノ一小部門トシテ等闌視サ レ爽りシ事モ敢テ坚シムニ足ラザラン。斯クシ テ耳科學獨立スルニ度ビ. 必然/要求ヨリ乳嘴 蜂窠 $=$ 關スル研究八俄カ二旺盛トナリ. 就中耳 外科二必要ナル局所解剖 =就テ，知見ハ著シク 精密ヨ加フルニ至レリーサレド蜂案系種タ相ノ 本態二關シテハ當時ニ於ケル斯界ノ權威 Schwarze u. Eysel(1873)(72), Wildermuth(1877) ${ }^{(106)}$, Zuckerkandl(1879) ${ }^{(117)}$, Bezold(1882)(17)等 スラ殆ンド注意スル所無ク唯漫然個人的善異 若シ强ヒテ託譯フ加フルナラバ遺傳性ノモノナ リト解シテ滿足シ居タリシコトハ之等諸家，斷

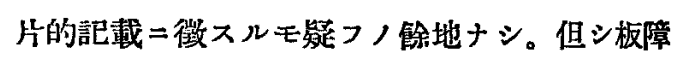

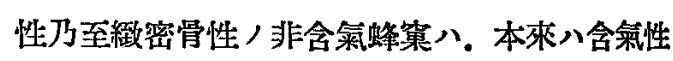

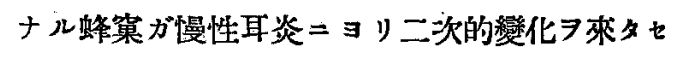
ルモノト一般二信ゼラレタリ。此中二在ツテ唯 1 人 Mouret $(1913)^{(66)}$ 八. 純肉眠解剖學的检 索 $=$ 基キ蜂荣系ノ變異八全り素因分配ノ個人的 相遠二存スルト解シ。積極的二遺傳說 少ホ初メテ合氣障碍八炎拝性骨隐牙質化/續發 症二非ズ卜述へ。從來ノ定說引敢然反䮎七り。

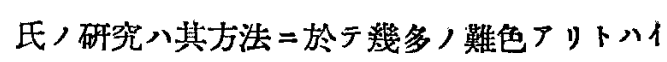

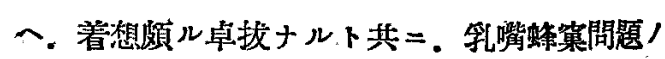
紛約セザル以前二於テ行ハレシコトハ大イ三注 日二價ス。

然ル=1918 年 Wittmaack(108) ガ從來主トシテ 慣用サレ來タリシ所謂肉眼的解剖 $=$ 代フルニ組 
織學的研究=ヨリ浩瀚ナル業靕 $コ$ 公ニスルニ及 ビ. 牫多ノ新生面濶然トシラ拓ケ. 且ツ期七ズ シテ乳嘴蜂巢發生本態=關スル再檢討，動機 $\ni$

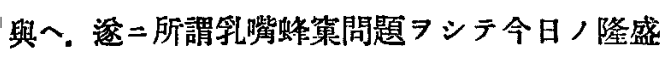
ヨ見ルニ至ラシメタリ。氏ノ所說二六佮ホ少カ |ラザル疑義 ヨ存スルト踓、モ. 正二劃期的業蹟卜

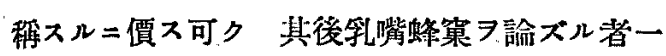
トシテ本業蹟ヨ引用セザル無キハ，以テ其一班 7箱フニ足ラン。今其大要 如シ。

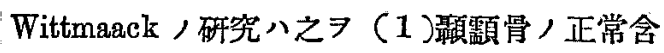

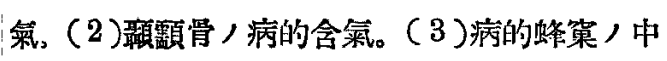
耳炎二對スル關係二大別シ得。

\section{(1) 频䫫骨，正常合氣}

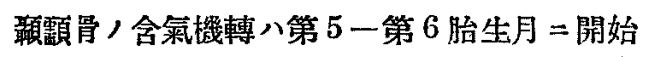
サル。即チ此時期二達スルヤ，歐氏管粘膜八鼓 室二侵入シ來タリ。内部ラ充塤スル胎生膠樣組

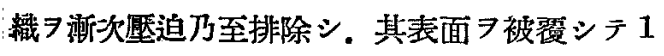

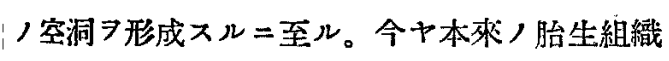
门上皮下結締織卜稱セラル。同樣ナル機轉入次

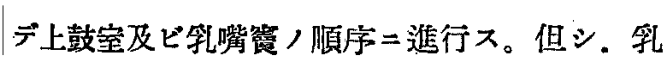

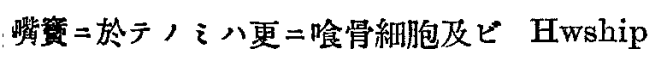
氏「ラクーネ」，出現並二之二伴つ上皮下結繀

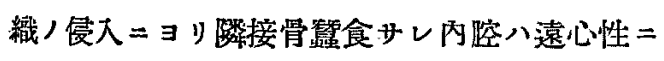
著シク搌大ス。以上ノ中耳 3 主要腔ハ 1 歲, 終 -2 歲ノ始迄=完成サレルモノンシテ. 第 1 發 育期卜稱七ラル。之二續キ大略 5 歲 $=$ 至儿迄， 間习第 2 發㕕期卜㭔ビ實二䗋杲系ノ完成サル、 㭙期ナリ。乳嘴筑壁二於ケル骨吸收八此時期 = | 於テモ少木持續七ラル、ガ. 該機轉八第 1 發育

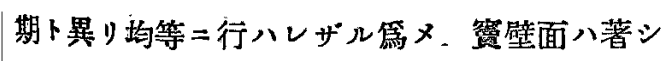
ク凹凸不平トナル。撸言七バ壁面ノ至ル所二骨

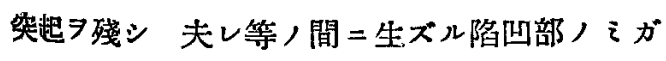

上皮下絬䋨織・゙充ス二至ル。斯クシテ此上皮下 結締織退化後。隣接粘膜ヨリ上皮沈降シ來タリ

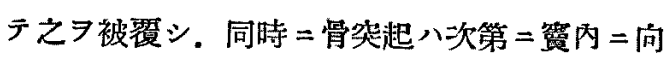
ツテ成辰シ.1歲ノ終リニ於テ著シク廣漠タリシ

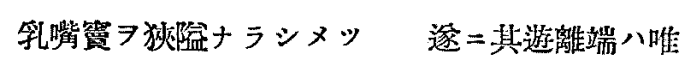

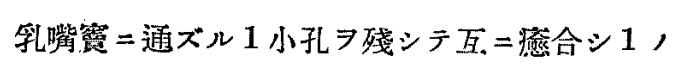
空洞 形成ス。之郎チ乳嘴䗋炛ニシテ母細胞卜 称七ラル。此新生蜂寅，內部二於テ八更二同樣 ナル機轉ガ反覆サル、結果沿二次微細網狀構造 桼タス二至儿(求心性含鼠)。佔ホー方末梢部殊 二乳嘴突赸尖端=向ッテ八. 全ク第 1 發育期卜 軘 テ合氮完了セル場合二於テ八. 乳嘴䗋榮八全乳 嘴突起腔ヨ充シ。乳嘴管 規則正シク排列シ。之ア遠ザカルニ從ツテ大サ

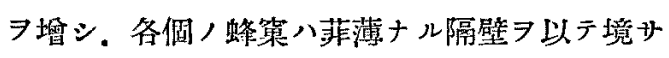
ル、像 ル啳トナリ䗋策，內面习被覆ス。斯ク含氡機轉 八大體 5 歲フ以ラ完了スルモ閒質性並二末梢性 ，發育八終生停止スル所䇛シ。サレド此時期= 於ケル含氣機轉八恢儿綬徐目ツ極メテ輕微ナル $=\exists$ り乳嘴蜂菑系，全貌八何等根本的，變化 7 受ケズ。乙ヨ要スルニ，完成サレタル正常蜘窠 系二於テ八個人的差異殆ント䉆ク，唯僅カ二末 梢部ノ形態ニヨリ軥別サル、場合モアルノ

\section{(2) 頙顬骨/病的合氣}

以上，訜キ棑タツタ所ニョッテ明カナル如 ク，含氯機轉八殆ンド壶う中耳被覆組織郎チ中

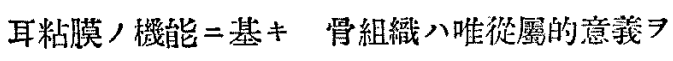
存スル二過ギズ。從ッテ中耳粘膜が蜂葟發者期 就中其初期二於テ峦碍けル、時八必然的二含氣 機轉モ抑制サル。而シテ其最大原因トナルモ， 八乳兒時代二於ヶル中耳炎ナリ。Wittmaack 
八所謂乳兒耳炎习 Goerke(1905)(26) 及ビ Rietschel $(1903)^{(62)}=$ 做七. 潜在性中耳加答兒：愈 性洆出性耳炎及ビ兩者，混合型二區別セリ。潜 在性中耳「カタル」トハAsehoff $(1897)^{(12)}$ ，提 唱七ル羊水，胎便．脂衣，或八吐物等，經歐氏 管迷入 ニョッテ起ル非菌性異物耳炎ノ謂ニシ テ. 臨林症狀ヨ全ク缺如シ剖检ニョリ初メテ認

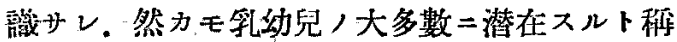
七ラル。本症八組織/筧殖及ビ器質化习特異卜 シテ中耳粘膜，肥厚 7 招爽ス。第 2 人滲出性耳 炎ト八中耳化縟症卜同一義ニシテ。其特性トシ テ中耳粘膜ノ繊維性菱縮 7 貽ス。但シ純繊維性 誉化八琵ダ稀ニシテ，通常第 3 ノ混合型即于潜 在性中耳加答韭，基底 $=$ 化膿菌が二次的 $=$ 感染 スル形式ヲトリ。中耳粘膜八部位=ヨリ或八肥 厚シ或八絭縮ス。之等耳炎ノ種類，强度及ビ發 現時期ナル 3 保件二應ジテ．正規，含氣機轉八 種々ナル程度二㜔碍サレ，茲二千姿萬態ナル䗋 巢像 招來スルニ至ル。郎チ例へバ障碍高度ナ ル場合二於テ八䗋案形成 ガ萎縮性粘膜, 續發证ナル時八，骨髓腔中二侵 入ス可キ上皮下結縍織 氣部八本秝，板障性骨，睢殘り．肥厚粘膜，埸 合二八．侵入シタル.上皮下結譈織/退行遷延ス 几霨メ二次的化骨 $=ヨ$ リ緻密骨性, 像 7 呈ス。 又炎症發現，時期＝應ジ例へバ 1 歲ノ終=於

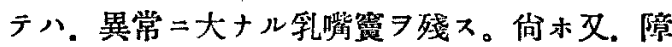
碍輕度ナル時八．發有鶴圍八正常二近キカ或ハ 正常以上ノ場合モアレド，隔壁厚ク排列不規則

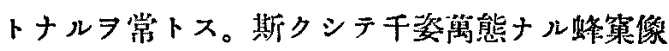
习招氷スル二至ルモノナルガ. 氏/統計二從へ ベ大多數唧チ約 $90 \%$ 八斯カル變化 7 蒙ムルト 1フ.

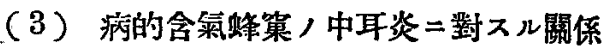

大略冒頭二述べタガ如シ。依ツテ热二八省 略下。

郎チ Wittmaack =徒へバ. 正常会氣=於テ八 佪人的差異八㱠ンド無ク，蜂杲系ノ種々相八全 夕䗋策發育期殊二其初期二作用七シ中耳炎/所 產物ニシテ．然カモコ八大多數/辿ル可揮命 ナリトスルニ在リ。要スル二䗋窂系發生狀態= 關スル外因說トモ稱シ得可シ。

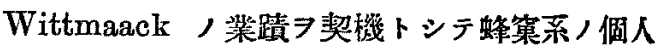
的差翼乃至其發生本態八大 $1=$ 注目\#ル、所 ナリタリ。郎チ Shea(1924, 1927)(73. in ,Carmo$\operatorname{dy}(1925)^{(19)}$, Van Gilse $(1926)^{(2)}$ 等八夫タ臨楬 的.「レ」的一組織解剖學的检查 $=\exists y$ Wittmaa (k) 所說 7 副鼻腔＝移シテ立證シ. $\operatorname{Brock}(1926)$ (IS)八「鼓膜像卜乳嘴蜂窠卜，關係二就テ」ナル 研究中 = 本問題 =論及 $\%$. 出生後, 第 1 呼吸 $=$ ヨリ中耳腔＝侵入スル宾氣が含氣現象開始／原 動力トナル事习前提トシテ.メBeck, J. (1927) (16)八乳嘴突起含氣卜副鼻膑含氣卜ノ間ニハ一定 ，相互關係つル事习認メテ，略了Wittmaack ，外因說７支持シ。其他 v. Eiken (1928) (22)， Goerke (1928)(27), Mygind(1928)(5n 等モ之ᄏ原 則的二承認七り。然ル二一面 Wittmaack 氏說 二反對七ル學者モ椹ダ多シ。即チV Voss $(1926)^{(98)}$ 八90\% =於テ見ラル、潜伏性乳兒中耳·「カタ ル」二比シ比较的稀ナル成人合菜抑制頻度卜厂 間，不均衡习指摘シ. $\operatorname{Marx}(1930)^{(48)}$ 八乱幻兒 耳炎 7 再檢討 =附シ。潜伏性中耳「カタル」ト 1 七急性參出性耳炎卜イフモ各獨立，疾患=非 ズシテ單二同一疾患，時期的差異二過ギズトノ 見解ニ達シ。從ツテ之等兩種耳炎ヨり夫及規則 正シク中耳粘膜，肥厚乃至萎縮习貽ストスル外 
因說 7 反殹シ。 Krainz(1925) $)^{(38)}$, Lange, W. (1928)(45)，Meyer, M.(1928;(51) 等八後年)急性 乳嘴哭起炎 $=$ 際シテモ亦中耳粘膜，肥厚 7 招來 シ得ル事 $ヨ$ 明カーシ. 霄二乳兒耳炎ノぇガ挠年

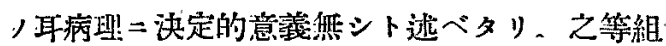
織學的追試 $=$ 對シ一方=於テ Knick u. Witte $(1923)^{(36)}$ 八. Wittmaack，組織學的檢查 $\exists$ リ

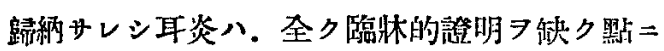
於テ不倩 ルル鼠取シ。1 歲以内二急性中耳炎 即子、Wittmaack，第 2 型耳炎 7 經過七儿事確 實ナリシ 25 例ノ患者 7 年蜍, 後「レ」學的= 檢查シ。㰌患側/高度ノ含氯障碍 僅カ 8 例二過ギザリシ事ョリ. 含氣抑柳/原因 八䖝り乳幼兒耳炎二䲞サ几可キモノ=非ズト提

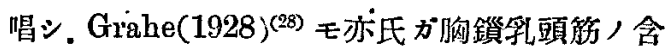

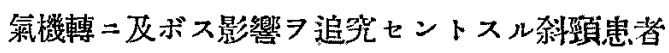
中3例八乳幼兒時代=中耳炎习經過七ルモノナ

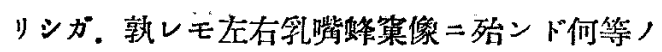
差異モ㫮カリシ事习特二强調シテ. Wittmaack 二反對セリ。倘木 Knick u. Witte卜略 2 同情 ノ研究习行ヒタル Eisinger(1928)(23), Kriegs$\operatorname{mann}(1931)^{(39)}$, Loebell $(1931)^{(46)}$ 等八單=事賽 习提供スルニ止ムルト述べ努メテ諭等，渦中= 投ズルトア避ケ居ルガ如キモ。其成績八明カ ＝外因說ト兩立シ得ザルモノナリ。

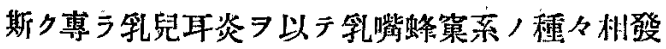
生フ說明スル能ハザルニ及ビ，期セズシテ遺傳 說ノ再登場 7 見ルニ至レリ。即チ Wagener

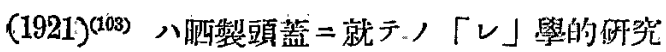

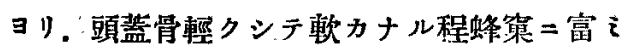

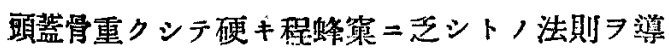
キ. Wittmaack ガ骨棈造八含氣機轉二對シ唯 從屬的意義ヨ有スル二過ギズトセルヨ㸝スルト

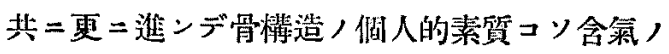
質及ビ量习決定スル根本因子ナラント推测七 J。Kretschmann $(1921)^{(3)}$ ，歐洲大戰中二得

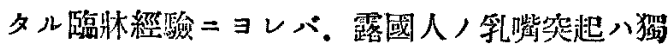

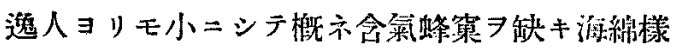

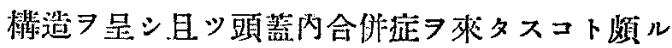
多シトイフ。Turner u. Porter(1922) 八(16) 八種

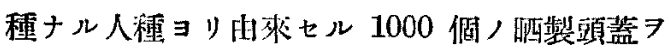
調查シタル結果. 含氣蜂窠八短徑頭䫑二最モ多

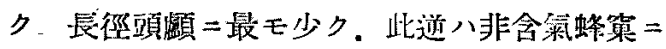
適合シ.中徑頭輀八其中間二位スルコト ニシ.一般二蜂案，發青八人種純粹ナル程良好 ナリト結論セリ。其他 Weidenreich(1922)(109), Talpis Uebermanc(1928)(90), Theissing(1930) (95) 等 乇乳嘴突把，含氮狀態 7 個人乃至種族特 性ト目シ遗傳譛二替セり。然少而シテ遗傳說 シテ著シク生彩 7 放ツニ至ラシメタルモノ八 Albrecht (1925)(1) 及ビ其一統，涤蹟ナリ。郎チ 從來，遗傅說八概亦消極的證明 7 根據卜七ル二 止マリシ焦邓揣杽憶测ノ域脫セザル點モ少カ ラザリシガ. Albrecht 八双生兒研究ニョリ直 接遗傅原基，解明习試i，乳嘴蜂篓八主トシテ 遺隹因子二因り文配サル、トノ積極的證明 7 具 ヘタリ。氏，着想八門下 $\operatorname{Schwarz}(1929)^{(69)}=$

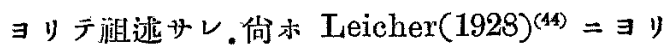
追試立證サレ，雨爽遺傳裞ハ漱ク有力ナラント

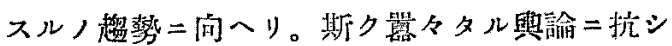
旗ネシモノカ，近時 Wittmaack ${ }^{(109)}$ 自身モ所說

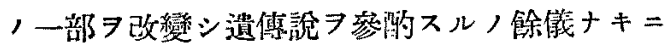
至リタリト踓モ。依然自己/牙城习堅守シテ䐻 ラズ. 其後モ主トシテ Albrecht (1931, 1932, 1933) (6. 7. タト擮烈ナル論守F $(1930,1932,1933)$ (110. 112. 113) Э續ケ互二相對恃又。 
唧ヅテ本邦ノ文献フ見ルニ，唯田中数授(1926) (91)八前記諸家卜全然热關係 $=$.耳炎, 家族病理

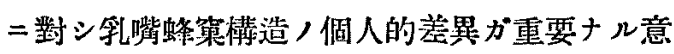

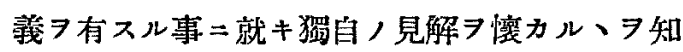
ルノ 組織學的研究中= 從來/文献及ビ自己ノ成績 $\exists$ 门本問题二諭及シ.「余ノ材料八操作前二必ズ 耳鏡 7 用七テ检查シ鼓膜穿孔八勿論其他鼓膜 溇濁. 萎縮及ビ洀痕等ノ病的變化アルモノ八嚴 二除外シ本研究二供セザリシ 以以。.含氮䗋菓 つ缺如シ居ルコト及ビ其不完全ナル發青、中耳

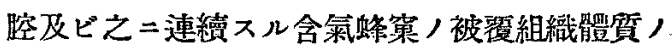

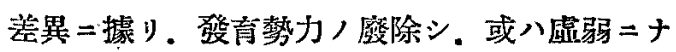
ルコトニ依リテ起ルモノニシテ。此被覆組織體 質八䗋䆲形式=緊要ナル役割司ルモノナルタ 思考セントス」ト述べ遗傳說二䝷シタルモ，余 ，卓見 7 以スレバ，氏，材料八例へ急性中耳 炎, 殘貽症アルモノ八悉ク除外シ得タリトスル モ. 乳嘴蜂窠問題二於テ根本的二重要ナル潜伏 性中耳加答兒ノ影響习批制スル事算クシテ斯カ ル結諭习下スハ.結果二於テ或ハ同一ナリトモ。 餘り大膽ニ過ダルト云ハザルヨ得ズ。

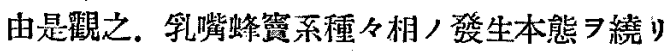
テハ外因詮卜遺傳說トアリテ今日倘木諭議ノ跡 ７斷タズ。近時遺傳說 キヨ加フルニ至リタリト踓モ. 直接遺傳關係 立證セントスル研究八 Albrecht, Leicher 及 ビ Schwarz ，3省ニヨリ行ハレシニ止マリ極 メテ䀃タタルノミナラズ. 此 3 者閒=於テスラ

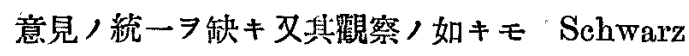
ノモノタ除キテハ不十分ナル照少シトセズ。而 シテ人種 7 異 $=シ$ 風土 7 異ニスル本邦人 $=$ 就テ 八斯方面ノ呼究八㫮舟ナル現狀二在り。一方乳

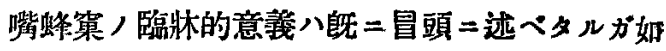
ク甚ダ重大ナリ。果シテ Wittmaack 氏說正シ クバ. 吾人專門琶家八Amberg(1922)(11)，提

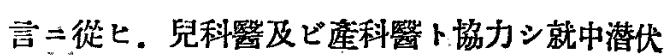

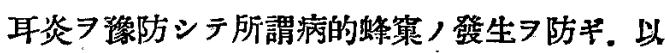
テ端倪スベカラザル後年ノ耳炎ト㗚フタ合理的 トス可ク. 若シ又. Albrecht，見解正鴊二當 レリトセパ. 體質學的乃至優生學的見地ョリ之 二對抗スルラ適切ト七ン。吾人八二途敦レヨ選 バンカ肢路三立チテ去就二迷フヤ久シ。茲二於 テ余八本問題，耳科臨牀＝辫ラス使命頻儿重大 ナルタ察スルト共 $=$. 之が決定的解決ノ枢メテ 㗨急事タルラ痛感ス。

之. 余吕由中教授御指導, 下=本研究 $ヨ$ 志シタ ル所以ナリ

\section{第 一章 \\ 研究方法並二研究材料 \\ 第一節 人類遺傳學研究方法}

動植物界二於テ極メテ規則正シク行ハル、遗 傳,法则ハ人類二於テモ亦適合ス可シトハ想像 ＝難カラザル所ナルモ。事實八之二反シ人類遺 傳二關スル知見ハ未ダ憶說ノ域 7 脫七ザ几蝛多

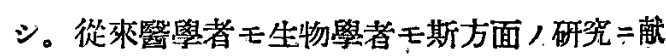
身的努力 7 傾倒シ來タレルニモ拘ラズ倘ホ且”

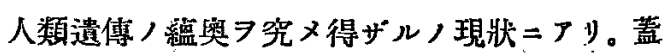
シ人類二於テハ彼ノ動植物界二於ケルガ如力實 驗的研究 $\ni$ 行七得ズ. 從ツテ或几形質保持者 任意二交配七シメ．更二同一兩親ヨリ生ゼル世 代間 $=$ 結婚 7 續行ス几等八，人道上嚴トシテ䛨 サレザル所ナルガ故二．吾人八唯無選擇二行ハ

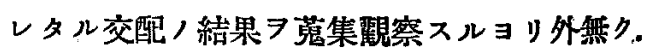
加フルニ人類ノ一生ハ甚ダ長ク然カモ其長キ 
世代間二生ズル子女ノ數ハえ=反シテ甚ダ少キ

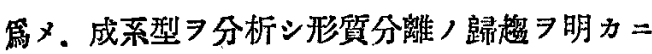
スルコト極メテ困難ナレバナリ，顸ツテ人類遺 傳學/研究八專亏繶計學的方法 $=ヨ ル$ 外無 有樣ナリ。

\section{(A) 個人統計的乃至歸納的方法 (Individualstatische od. Induktive Methode.)}

（1）家系的检查。メシデル則，「互 $=$ 對 7 ナス形質保持者ノ交配ニシリテ生ズル後續世代 =就キ其形質分離/狀態 7 追跡スル」トイフ原 理习應用シ。一家系内二於ケル一定形質 7 㑑人 的二統計シ以テ掯傳ノ型式 7 歸納スルオ゙法ニシ テ、專ラ家紊圖ニョルモノナリ。

（2）双生兒研究。双生兒 7 介シテ人類遗傅 ノ神秘ヨ窥ハントスル方法ハGalton，創意= 基キ. 本來家系的研究ノ一部門トシテ挰頭セル モノナルガ. 其後比較發生學ノ進步卜高等數學 ノ襍足ニヨリ之ガ亭有スル遺傳物翼二關シ精密 ナル知蛓ヨ留ラス 今ヤ人類遭傳學研究二於テ最モ樞要ナル地步 確保スルニ至レリ。郎テ一卵性双生兒八受精七 ル1個，卵細胞／2等分ニヨリテ生ジ從ツテ其遗 傳物質八等質等量ナリト，見地 $=$ 立脚シ，一毌 兒二現ハル、總テノ相似ハ遺傳性ナリトシ，之 二反シ美異 ト解スルニアリ。而シテ此成績八Siemens ${ }^{(77 * 78)}$ ，發案二ナル二卵性双生兒（同一經期二屬スル 2 個, 卯ガ殆ンド時 7 同ジタシテ各獨立二受精 シ生ジタルモ，從ツテ略こ等シキ環境祀! 二在 ルモ遗傳物質／分眍（平等ナラズ）７對照トシ

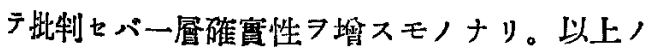
原則 7 敷衍スル時次/如キ事項 7 決定走シ得。
1. 一般ニ稀ナル形翼ガー卵性双生兒／兩兒 ニ於テ一致スル時ハ恐ラク之习遺働性ナリト決 定シ得。

2. 例へ稀ナラザル形質トイヘドモ多數ノ材 料二就テ調查シ且ッ二卯性双生兒 7 對照檢查ス ル時八遺㯖性 7 決定シ得。師チ一形質ノ相似シ 或八相俱=發現スル頻度ハ。一卵兒=於ケルョ リモ二卵兒二於テ メ二卵兒二於ケルョリモ單 胎同胞二於テ減ズ。的チ一般二親螕關係稀薄卜 ナルニ從ッテ低下スル關係成立ス。

3 . 或形質ガ双生兒网兒間二於テ各々異ルハ 外的因子ノ影響ニヨルモノニシテ。從ツテ外因 ノ程度 $\ni$ 推测シ得。

(B) 集團統計的乃至演繹的方法

(Massenstatische od.

Deduktive Methode.)

既述，如ク人類=於テハ 1 世代=生ズル子女 ，數八枈ダ少數ナルガ故二．或形質二就キ多數 家系,多數偑體 統計的二綜括調查スルモノ= シテメンデル則/所謂「各世代二現ハレタルー 定形質 $フ$ 示ス個體，數 シ，等ラ生物测䇥學的方法二據ルモノナリ。

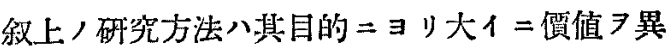
ニス。燅二閣題トナレル乳嘴䗋杲ハWittmaack 二從へバ殆ンド渠ク中耳炎ナル外的影響习蒙ん リタルモノナルガ故二：之ガ遗傅關係 二當ツテ八常二外因习㕍慮セザルベカラズ。サ レバ一般=慣用サル、多數ノ家系 7 㢣集シ多數

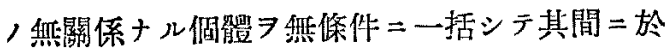

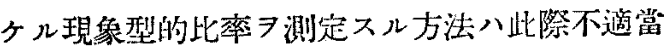
ナリ。（シナラズ乳嘴䗋策ノ如キ特殊方法 テセザレバ䫏フ能いズ且ツ記錄二殘シ得ザル解

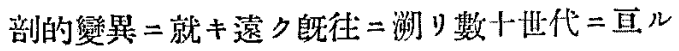


ガ如キ家系圆习求ムルコト，不可能ナルハ言 俟タズ。況ンヤ本研究二於テ乳嘴䗋窠描出二供 セシ「レントゲン」ガ耳科學=應用セラレテヨ リ僅々 30 年 7 出デザルニ於テ 制尹要スルハ Meyer, M. ${ }^{(53)}$ 及ビ Schwar: ${ }^{(70.71)}$ ノ研究ナリ。即チ之等八近時相前後シテ人胎兒 二於ケル中耳船生組織 7 組織學的 $=$ 检查シ遗傅 說ニ一ノ確證 ヨ具へタリト述ベシモ。 氏等ノ研

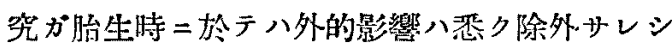
モノト/前提二出發セシ八早計ナリ。郎于胎兒 卜踓モ羊水ナルーノ環境祼二在ツテ常二其影響 ア蒙ムリ：殊二材料トサレタ几胎兒ノ大多數八 不正規分始二由豨スルモノナルガ故二胎兒自身 八固ヨリ既二子管及ビ其內容モ多大/變化 7 受 ケ居ル可キ八察スルニ難カラズ。, カル所見八標本作製上，不僃又八死後變化 $=\exists$ リテモ生ズルトテ Wittmaack ${ }^{(12)} ヨ リ$ 痛烈=反

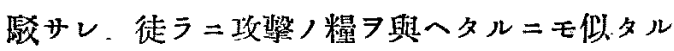
結果ヨ招ケリ。要スルニ，遗傳學說ヨリ見レバ. 胎兒中耳゙ト踓モ等シク現象型タルニ變り然ク

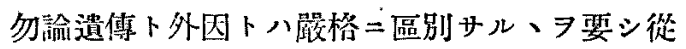
ツテ氏等ノ着想八本研究二適切ナリト云フヨ得 ズ。然ル二双生兒二於テ八，既述ノ如ク，分配 七ラレタル遗倛物質 7 德知シ。一方外因/程度 ヨモ推测シ得ルラ以テ 叙上ノ缺陷习補フト共 二必要ナル佟件 ヨ充スモノナリ。且又. 一船二 解剖的變思，遭傳研究二於テ八彼，擎啞. 短指 症等, 如ク特殊形質，存否 7 追筧スルニ非ズシ テ，其目的トスル所ハ一形質=關スル相似，程 度习調查スル $=$ 在ルガ故二. 此黑上於テモ亦双 生兒研究八極メテ適切ナリ。

依ツテ余ハ先ヅ双生兒二就テ遗售，有無 7 確定 シ. 次デ家系的並 =集團統計的检查 $=ヨ$ リ之
補遗スルノ方針ヨ探ルコト七り。

\section{第二節「レントゲン寫真撮影法}

及ビ含氣型分類

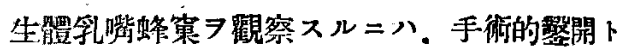

「レントダン」透視トノ2途アルモ。前者八偶 偶乳嘴突起炎二際シ施行シ得ルモノニシテ 素 ヨリ之ヨ何人二モ通用シ得ルモノ=非ズ。從ッ テ余ノ研究八專ラ「レ」ヨ介シテ行ハレタリ。

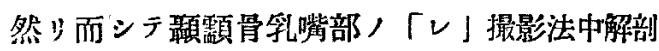
的關係ヨ最モヨク明示スルハ Schuellèr(190万) ${ }^{(68)}$, Lange, S. (1903)(11), Sonnenkalb(1913) 等ノ頖艏骨側面觀 撮影法八其考案者二從へバ各々幾多，長所ヨ有 スルガ如キモ．原則的二八大同小異ノモノト自 テ考支一然カル可ク. 余い方法ノ此較的簡便ナ ル點二於テ Schueller，方法ア應用セり。郎 于.

體位。橫臥位又八腹臥位トス。

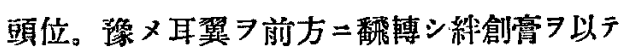
耳前部 =固定シタル後. 撮影側耳ブ下ニシ. 頍

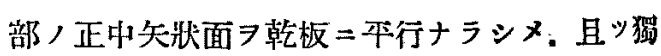
乙水平面 $夫$ 夫倕直ナラシム。此位置二於

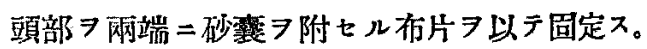
斯クシテ中心光線 7 耳垂直面二一致シ. 猡乙水 平面二對シ影頁側へ $25-30^{\circ}$ 開角七シムル㮈 $=$ 投射スル時八非撮影側ノ乳嘴蜂㪙 7 完全二除 外シ得ルナリ。

管球。绑瓦斯管球，之二直徑 $8 \mathrm{~cm}$, 長专 $40 \mathrm{~cm}$ ，鉛製圓筒 $尹$ 附 。圓筒，上部=八厚サ $0.5 \mathrm{~mm}$ ノ「アル ブっキー氏「ブレンデ」使用セズ。 焦點乾板距離。 $60 \mathrm{~cm}$ 。 露出。60 3v. 20 m.A. ニテ約 2 秒トス。 
「フィルム」，1ーストアン社製ニシテ。二重 增感紙使用。

一般=「レ」像ハSteure1 ${ }^{87 ?}$ ，云フ如ク贔際 ノ解剖像トヨク一致スルモノナルモ。頡察セン トスル部分ノ多ク八䫓蓋骨中深ク埋淁セラレ。 又深部螦菑八互 $=$ 重盢スル等ノ特殊解剖的關係 ト㧘シキ個人的差異=ヨリ像, 明膫 モ稀ナラズシラ 其正確ナル制讀八常二必ズシ

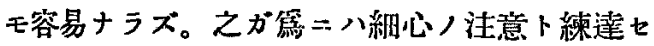
ル热練习要スルコト勿論ナリ。余ハカクシテ得

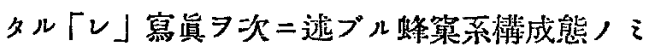

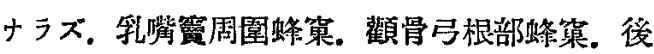

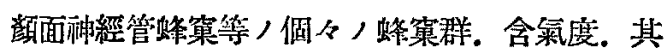

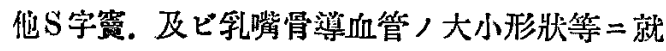
キ詳細且ツ精密二覞察シ. 少ホ㫐通ハシキ場合二 八再撮影习行七又八他ノ撮影ヨ行ヒ又八他ノ撮 影方法习储用シテ診斷ノ確筧习期セり。

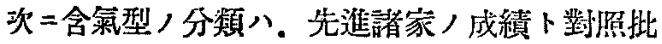
刵シ. 或八臨林上一定/概念

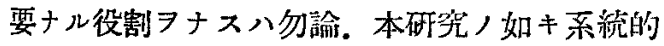
觀察二際シテ八必要缺グベカラザルモノナリ 然ル二徒來二於ケル分類八多歧多榡ニシテ一定 セズ. 人ヨシテ據ル所二迷ハシムルノ觀アリ。 コハ「レ」的. 組織的. 解剖的乃至臨懒的等學 者ニヨリ其检查方法习異ニスルガ焦ト云ハンョ

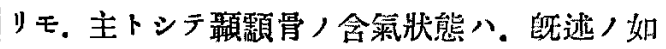

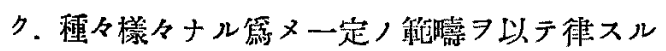
コトノ極メテ困難ナルコト及ビ含氣本態=鬬シ 今尚木多大，鼠點 7 存スル＝因ルモノナラン。

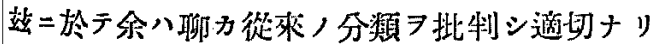
ト信ズル分類ヨ行ハントス。 秏踇突起，合氯狀態 7 表現スル二含氣性。含氣 板㜔温性。板㜔性乃至緻密骨質性, 3 型 7 以
スルコト八. Zuckerkandl(118), Politzer ${ }^{(60)}$, 占 キョリ現在二至ル迄愩用サル、所ナルモ. 本分 類法八單二䗋篓，發有底： セルモノニシテ 僻リ二藍然的二過ギ. 俆り $=$ 非科學的ナリト云フ可シ。近時辰足，進步 7 逐 ゲ著シク精譈トナレル含氯學說＝立脚セル分類

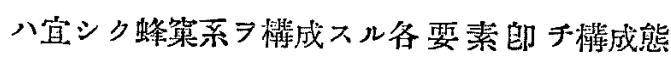
(Strukturzustaende) $=$ 細心八沬意习㸡ヒタル モノナラザル可カラズ。此處二蓝成態トイフハ。 䗋策/發育度。各個蜂策/形態。排列. 隔壁. 含氮ノ終止狀態. 非含氣部二於々儿骨棈造， 6

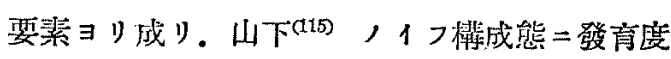
/加ハリシモノニシテ 略に Wittmaack ノ構 成像 (Strukturbilde) =匹敵スル意味有ス。 双這般，關係二留意七几從棑，分瀬中其重ナル モノタ擧グ檢討セン。

\section{Wittmaack，含氣型分頼}

(I) 正常含氣(Normale Pneumatisation)。 蜂策八全乳嘴突起腔 7 充シ。蜂箱ノ大开中等大 ニシテ．乳嘴赛タ中心トシ放射狀二規則正シク

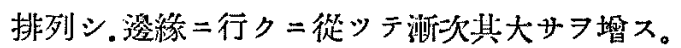
周園骨質卜，境界明膫ナリ。細胞間壁八菲緎二 シテ. 細胞內腔八含氣度良好ナリ。

(II) 病的会兆 (Pathologische Pneumatisation)。正常粘膜ノ病的變性挙物ニシテ 其 質及ビ量二應ジ䄻タナル含氣狀態习來タス。

(A) 肥厚粘膜二於ケル完全含占抑附

(Vollstaendige Pneumatisationshemmung bei hyperplastischer Schleimhaut)。鼓室.

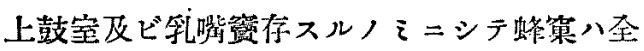

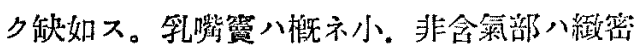
骨性ナリ。

(B) 肥厚粘膜二於ケル部分的含涞障碍 
(Teilweise Pneumatisationsstoerung bei hyperplastischer Schleimhaut)。障碍，程 度二應ジ種アナル像 牮性或八大小八蜂篓混在シ排列著シク不規則 トナリ，周園トノ境界明膫ヨ缺グ。向ホ合氣 度低ク，非含璘部八緻密骨性ナル等 7 特性卜

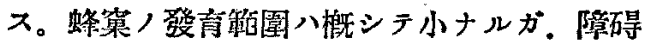
輕微ナル場合二於テ八略、正常發育稆圍 =一 致シ及霆ミ夫レ以上ナルコトアリ。

(C) 繊維性粘膜=於ケル完全含氣抑制 (Vollstaendige Pneumatisationshemmung bei fibroeser Schleimhaut)。中耳，3主要

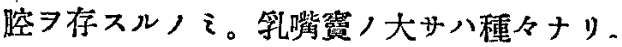
非念氣部/骨八板㜔性ナリ。

(D) 纎維性粘膜二於ケ几部分的含氣障碍 (Teiweise Pneumatisationsstoerung bei fibroeser Schleimhaut)。蜂窠小うシテ隔壁 厚キコトモアレド，多ク八正常含氣ニシテ唯

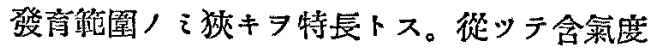
比较的高シ. 非合氣部骨ハ勿諭板㜔性ニシテ 合氣部トノ境奋尖銳ナリ。

（E）肥厚性纎維性粘膜二於々ル含氣塆碍 (Pneumatisationsstoerung bei hyperplastisch-fibroeser Schleimhaut)。主トシテ肥

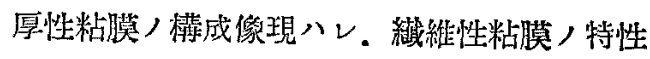

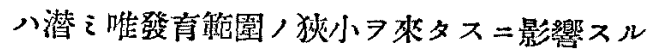
'

本分類八Wittmaack ガ䗋窠粘膜，組織學的 所見习基整トシ獨自ノ見解ヨリ行ヒタルモノ=

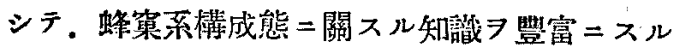
ト共ニ分類ヨ著シク科學的ナラシメタルモノナ ルガ. 既逝ノ如ク氏，合氣說 $=$ 八根本的二承認 スル能ハザル點アルラ以テ直チニ踏用シ得ザル
ハ言テ侯タズ。從ッテ Runge ${ }^{(6)}$ ( 8 型). Hesse (32) ( 5 型)等/分類八. 雨者共 = Wittmaack， 門下=シテ唯方法７變へ「レ」學的二師家ノ見 解习祖述七ル事二想到セバ，其可否八自カラ明 カナル可ク. 佮木 Sonnenkalb(85) (4 型). Beck, J. ${ }^{(16)}$ ( 5 型) 等) 分類モ Wittmaack 氏說= 㱠ンド無批制的追從アナセルモノニシテ. 殊ニ 前者ノ如キハえラ簡略化サントシテ生ジタル種

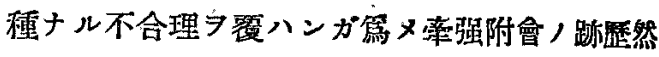
タルモノアリ。亦用フル二足ラス。 從來二於ケル分類中最壬進步シ且ツ安當ナリト 考へラル、八. Sehwar: ${ }^{(69)}$, 载汇 ${ }^{(110)}$, 及ビ山下 (119) / 分類ナリ。此內義江. Schwarz 八「レ」 學的=.山下八純解剖學的=分類セシモノナリ。 今之等諸家/分類 7 据銑七バ次ノ如シ。

\section{Schwarz，含氣型分類}

第 1 型。異常二發育七ル蜂巢フ有スルモ，

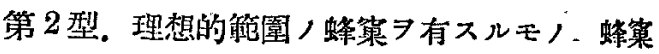
八乳嘴突把, 固有投影筙圍 $尹$ 充スモノ =シ テ所謂正常筙圍二一致ス。

第 3 型。䗋窠ノ發育中等度ナ汇的。

第 4 型. 䗋軋ノ發有僅少ナルモ，

第 5 型. 蜂菑, 發育 7 全ク缺如スルモノ。

而シテ第 1 型ヨリ第 4 型迄二於テ八排列狀 態、䗋穼ノ大サ. 間壁, 厚薄 7 區別シ。第 5 型 ニ於テ八非含氮部二關シ板陪性及ビ䋑密骨性， 別フ設ク。斯クシテ生ズル種々ナル組合セ7記 號ヨ以テ表現セり。

\section{義汇ノ含氯型分類}

第 1 型，䗋巢正常ナ儿乳嘴塋起。Wittmaack , 正常含菉卜全ク同一, 像 7 呈ス。但灌

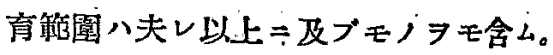
第 2 型．小細胞性乳嘴突起。䈥圍ハ正常ナルモ。 


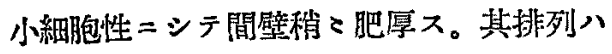

蜂笨全般一㨾ニシテ不規則ナラズ。

第 3 型。蜂菑籍園狹小ナルモ細胞排列規則的ナ ルモノ.

第4 型. 蜂宲範圍正常又八正常以上ナルモ細胞 排列不規則ナルモノ

第 5 型. 蜂笨渞圍陝小ニシテ正常域二達セズ 細胞排列不規則ナルモノ. 細胞間壁肥厚ス。

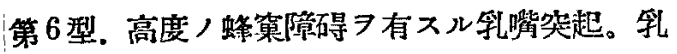
嘴䨳籁圍 $=2.3$, 細胞群影 そ=镯ス。非含氮部骨八緻密性ナル場合卜 板障性ナル場合フリ。

本分類二於テ八發青度二關シ 4 種類 7 區別 ス。郎千第 1 型及ビ第 4 型八正常又八正常以上

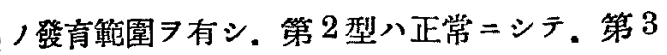
型及ビ第 5 型八笔圍正常域二達七ズ。第 6 型八 殆ンド全ク發育缺クモノナリ。

\section{山下，含氣型分類}

第 1 型. 蜂策發育度 I.

第 2 型，蜂㮤發育度略 八比較的正規ナル構成態 $尹$ 示スモ，

第3型。蜂巢發育度略正常ナルモ不正ナル或八 稍 $ミ$ 不正ナル莓成態ヨ示スモノ

第4 型. 蜂巢發育度稍 稍々不正ナル榡成態ア示スモ，

第 5 型。蜂策發育度秒 稍 、不正ナル檏成態 $尹$ 示スモノ 第 6 型. 䗋集發青度甚ダ小ナルモノ 即千發育度二關シ 4 階梯フ設ヶ. 其内第 1 階 梯'第 1 型. 第 2 階梯, 第 2 型及ビ第 3 型八 Schwarz，義江等，モ，卜同意䇅７有シ．第 3 段階（第 3 型及ビ第 4 型）ト第 4 段階（第 5 型）

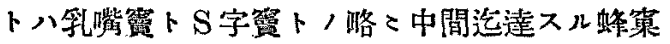
シ夫タ最大或ハ最小限度トシテ區別セリ。但シ 正規卜八中細胞性ニシテ . 排列. 方向共=規則 证シク 間壁非薄ナルモノ 胞性ニシテ. 排列. 方向共二不規則. 間壁厚キ モノタイフ。

以上，分類 $=$ 於テ特 $=$ 注意又可キ八. 所謂正常

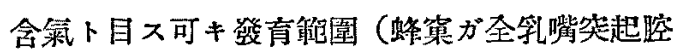
ヨ充スモノ) ヨ示スモノ=於テモ排列不規則ナ

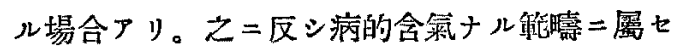
シメラレタルモ/、中ニモ山下ノ所謂正規/構 成態アルラ認メシコトナリ。郎チ之等諸芜八忠 實二自家所見 $ヨ$ 基礎トシ. 更 $=$ Wittmaack 氏 詨 ア行ヒタルェノナルガ. そヨ余ノ研究上二雇用 スルニ八佔木线分不倩ノ點アルタ知レリ。依テ 余八以上諸氏，分類，長短习溚へ之ヨ参啲シテ 次,如分類セリ。

第 I 型。蜂穼，發育度正常以上=良好ナルモ

第 II 型. 䗋蜜ノ發有度正常ナルモノ。

第正型，䗋寞，發育度中等展ナルモ！

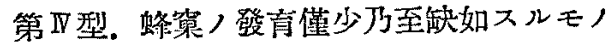
以上 4 型, 發育度八次, 如ク規定ス。臫手第 1 型八䗋菓力゙乳嘴突起，固有投影籍圍 7 充 $ス=$ 止

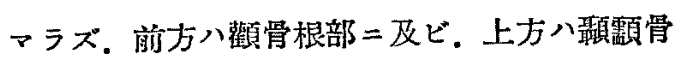

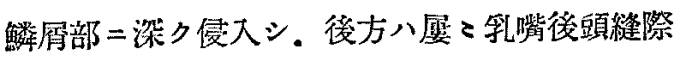
二迄達スル程，發育断儿佳良ナル一群ナリ，第

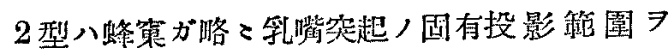
充スモノンシテ，發青度ノミ八Wittmaack，

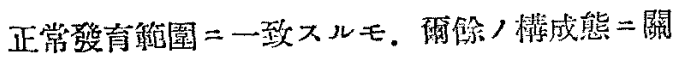
シテハ正常ナルモノト然ラザルモノトヨ含ムコ

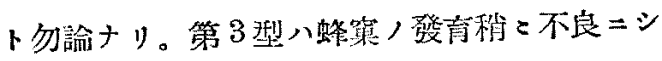


テ $\mathrm{S}$ 字管像ノ略

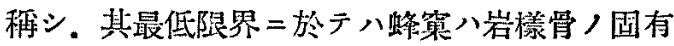
投影嘶園内 = 限局少儿。最後，第 4 型八䗋菑全

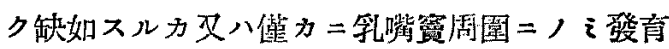
タ見ルモノナリ。而シテ第 1 型ヨリ第 3 型过二 於テ八排列狀態二關シ（1 規則的。（2)不規

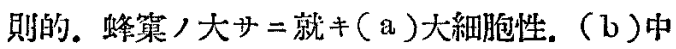
細胞性. (c)小細胞性, 間壁/状態 $=\exists y(\alpha)$

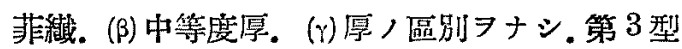

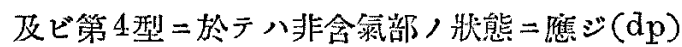
板隐性。（K)緻密骨性ト 7 分ツ。但シ第 1 型

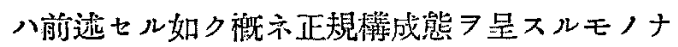
リ。佾ホ必要二應ジ總テ，含氣型二於テ $\mathrm{S}$ 字貿 , 膨隆度 $7(\mathrm{hg})$ 高度. $(\mathrm{mg})$ 中等度. $(\mathrm{gg})$ 輕度 ，3階梯二分チテ觀察七り。

而シテ余/分類法ニヨリ含氣狀態 $尹$ 留略二表八 スニハ，例人バ䗋笨，登著シク良好ニシテ 中細胞性. 排列規則正シク。閒壁菲緎ナル時=

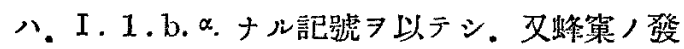
育殆ンド缺如シ。非含氣部八板㜔性骨ニシテ

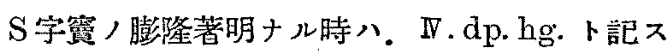
ルガ如クニシテ 以下そニ集ズルモノトス。

\section{第三節 材 料}

本研究二供シタル材料八，同性双生兒 41 組

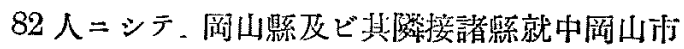
及ビ其近郊居任者過牛数

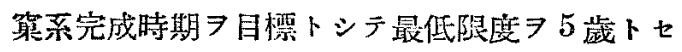
リ。材料, 蒐集八昭和 7 年 10 月以來開始セシ

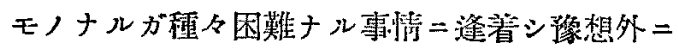

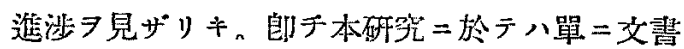

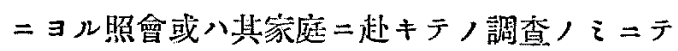
足ラズ 常ニ被检者ヨ一定個所二招致シテ「レ」 的. 生物測定學的乃至瀶林的ニ詳細ナル检少 7

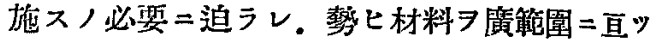
テ求ムルコトハ經畄上堪へ得ル所二非ズ。又該 當者中二於テモ或八研究二理解习缺キ再三人鲶 請モ空シク或ハ不當/金員 7 要求シ遂二落念 ルノ止ム䑤キ場合モ少ナカラズ。殊二双生兒八 比較的稀ナル對象ナル上＝特異形質保持者ナり

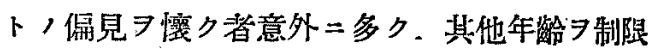
シ，同性ナルコト 限定シタル等ノ第メ一詹蒐 集习困難ナラシメタリ。

Leicher $^{(4)}$ アシテ Zu Vererbungsstudien beim Menschen braucht man zeit u. Geld. ト

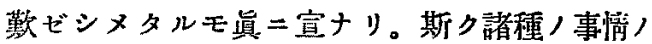
腺邓双生兒八其數二於テ著シク制限セラレシモ 亦止ムラ得ザル所ナラン。

因二，双生兒/住居氏名調查二關シテハ防町村

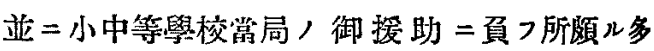
シ。多本研究ノ趣旨习諒トサレ，身 7 以テ貴重 ナル材料习提供サレタル各位二龇シテハ. 謝ス ルニ言葉然キ次第ナリ。䓋二浒セ記シテ感謝， 微意习表ス。

\section{第二章}

\section{調 查 成 績}

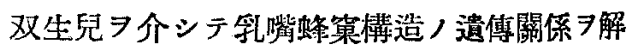
明セントスル人研究八.僅カ $=$ Albrecht ${ }^{(1)}$, Leiche1 ${ }^{(44)}$, Schwar2 ${ }^{(69)} ， 3$ 省ニヨリ試えラレシ 二過ギズ。其中 Schwarz，稍に系統的ナル研 究以外八䜺察甚ダ不十分ナルノミナラズ 3 者間 二於テスラ意見ノ統一フ缺り。茲 $=$ 於テ余八双 生兒研究

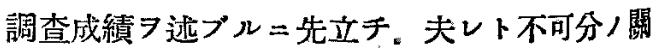
係ニアル卵性診断ノ概要 应ベン。 第1章=於テ述べシガ如ク双生兒ニハ1卵性ト 
2 耶性卜，別アリテ. 各々人類遗傳學研究上獨 自/意義ヨ有入。從來ヨリ之ガ鑑別ニ八主トシ テ卵膜診斷法用ヒラル。即テ卵腔單一ナル時八 常 $=1$ 卵性ナルガ 2 愠ナル場合中隔が唯 2 葉， 羊膜ヨリ成レバ 1 卵性ニシテ. 左右 2 葉/羊膜 ，中央二䋐毛膜 7 存スレバ 2 卵性ナリ。然ル= 本法=於テハ中隔，毁損或八剩離困難等，䉆又 確診ア下シ得ザル場合アルノぇナラズ單一䄉毛 臊兒ニシテ 2 卵性ナルコトアリ。乙二反シ複䋐 毛膜兒中ニモ1卵性ノモノアルボ故=理猃的二 玉缺陷厂り。近跨 Siemens ${ }^{(88.79)}$ ガ人類學的皮膚 科學的見地ヨリ案出七几所謂相似諗断法 (Aehnlichkeitsdiagnose) 八 V. Verschuer ${ }^{(99.101)}$, Decking( $^{(21)}$, Curtius ${ }^{(20)}$ ，䟥非及ど福店( ${ }^{(34)}$ 等其 他多敷學者ノ追試 二確實ナリトイフ。其原理トスル所八慨二遗傅 性確認サレ且ツ多性遗德性 (Polyid) ナルガ如 キ形質 7 可及的多數選擇シ. 之等二就キ双生兒 兩兒間人相似度习調查シ. 卵性 7 淕定セントス ルモノナリ。象モ角余，材料，如キ年長兒二於

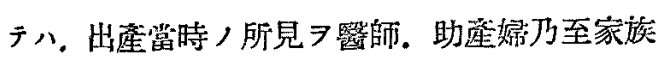
等二就テ求ムルモ，或八記録散邀シ或八記憶不 明膫トナリ。其詳細二接スルコトハ筧ダ困難ナ

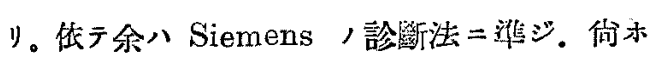

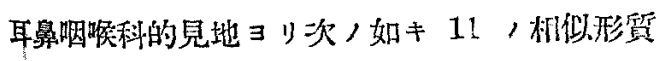

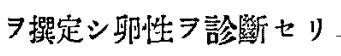

(1) 毛崕, 色涬形狀

(2) 眠, 色

（3）皮展, 色

(4) 䙵毛並二喕髮，生一際

(5) 口篮, 形狀

(6) 萄列及ビ啮牙ノ小小

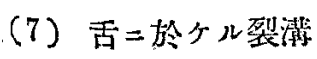

（8）會厥軟骨：形狀

(9). 薠 貌

(10) 血液型

（11）耳翼及ピ外鼻，解剖的變異

(生物測定學 $=\exists ル) 。$

而シテ以上ノ相似形犋二就キ双生兒 7 检查スル

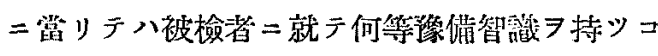

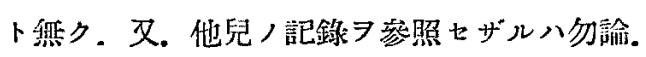
出來得ル限リ八長キ間隔习琶テ爾兒习别々二检

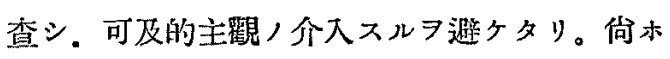

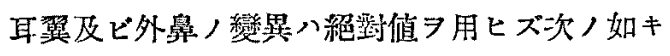
各種指數ヺ以ラ゙裴現セリ。

(A) 耳 翼。

(1) 骨相學的耳指数 (Physiognomisehe Ohrindex)

$$
=\frac{\text { 最大耳幅 }}{\text { 最大耳長 }} \times 100=\text { Physiog I }
$$

(2) 耳底長指数 (Ohrbasis-Ohrlaengen-Index)

$$
=\frac{\text { 耳 }}{\text { 最大耳底 }} \times 100=\mathrm{BLI}
$$

(3) 耳 保指 數 (Ohrlaeppchen-In(dex)

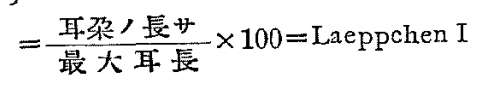

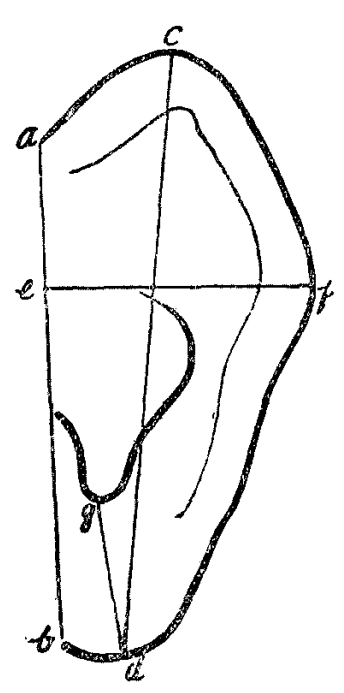

但シ榃二示ス如り 耳底 (ab)八耳翼 ,上下附着默間, 直線距離。最大耳 長(cd)八耳翼八最 上端卜耳采ノ最下 端間, 直線距䆶。 最大耳幅(ef)八後 部耳䌞/最後站卜 耳底卜，間，最短 距䠰。耳罙ノ長サ (dg) 八珠間㵶痕 
ノ最底點卜耳架ノ最下端間ノ距離ナリ。 (B) 外鼻。

(1) 鼻高幅指数 (Hoehenbreitenindex d. Nase)

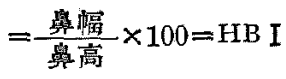

(2) 鼻幅哚指數 (Breitentiefenindex d. Nase)

$$
=\frac{\text { 蕃深 }}{\text { 悬幅 }} \times 100=\mathrm{BT} \mathrm{I}
$$

但シ鼻幅八两側鼻翼間,最大幅徑. 鼻高八「ナ ジオン」ヨリ學頭二至ル直線距離。鼻深八鼻翼 ノ烦皮膚=附着スル最深部 リリ鼻頭二至ル距離 ナリ

而シテ計算ハ次ノ公式 $=ヨ ル 。$ $I=\frac{a}{b} \times 100$ 但シ $I$ 八指數. a ハ小ナ儿數值. $b$
ハ大ナル數值习表ハス。

$\mathrm{E}(I)=$ 指數，覞察誤差 $= \pm \frac{100 \sqrt{\alpha^{2} b^{2}+\beta^{2} \mathrm{a}^{2}}}{\mathrm{~b}^{2}}$ 但シ - 八數値 $\mathrm{a}, \beta$ 八數值 $\mathrm{b}$ 人覞察誤差ナリ。 2 個人, 指數 7 比較スル

$I_{1}-I_{2}<2\left|E\left(I_{1}-I_{2}\right)\right|$ ナル時八雨指數，值八压 翼㤵力

$\mathrm{I}_{1}-\mathrm{I}_{2}>2\left|\mathrm{E}\left(\mathrm{I}_{1}-\mathrm{T}_{2}\right)\right|$ ナル時ニノ哃指數へ相 違スルモノト制定ス。

但シ $\mathrm{E}\left(\mathrm{I}_{1}-\mathrm{I}_{2}\right)$ =兩指数/密/誤差

$$
= \pm \sqrt{\left[\mathrm{E}\left(\mathrm{I}_{1}\right)\right]^{2}+\left[\mathrm{E}\left(\mathrm{I}_{2}\right)\right]^{2}} \text { 但 } *\left|\mathrm{E}\left(\mathrm{I}_{1}-\mathrm{I}_{2}\right)\right|
$$

八正負 $=$ 關係無ク絕對值 7 示ス。

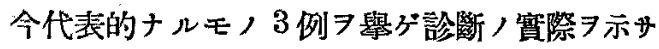
ะ。

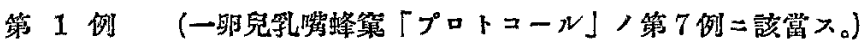

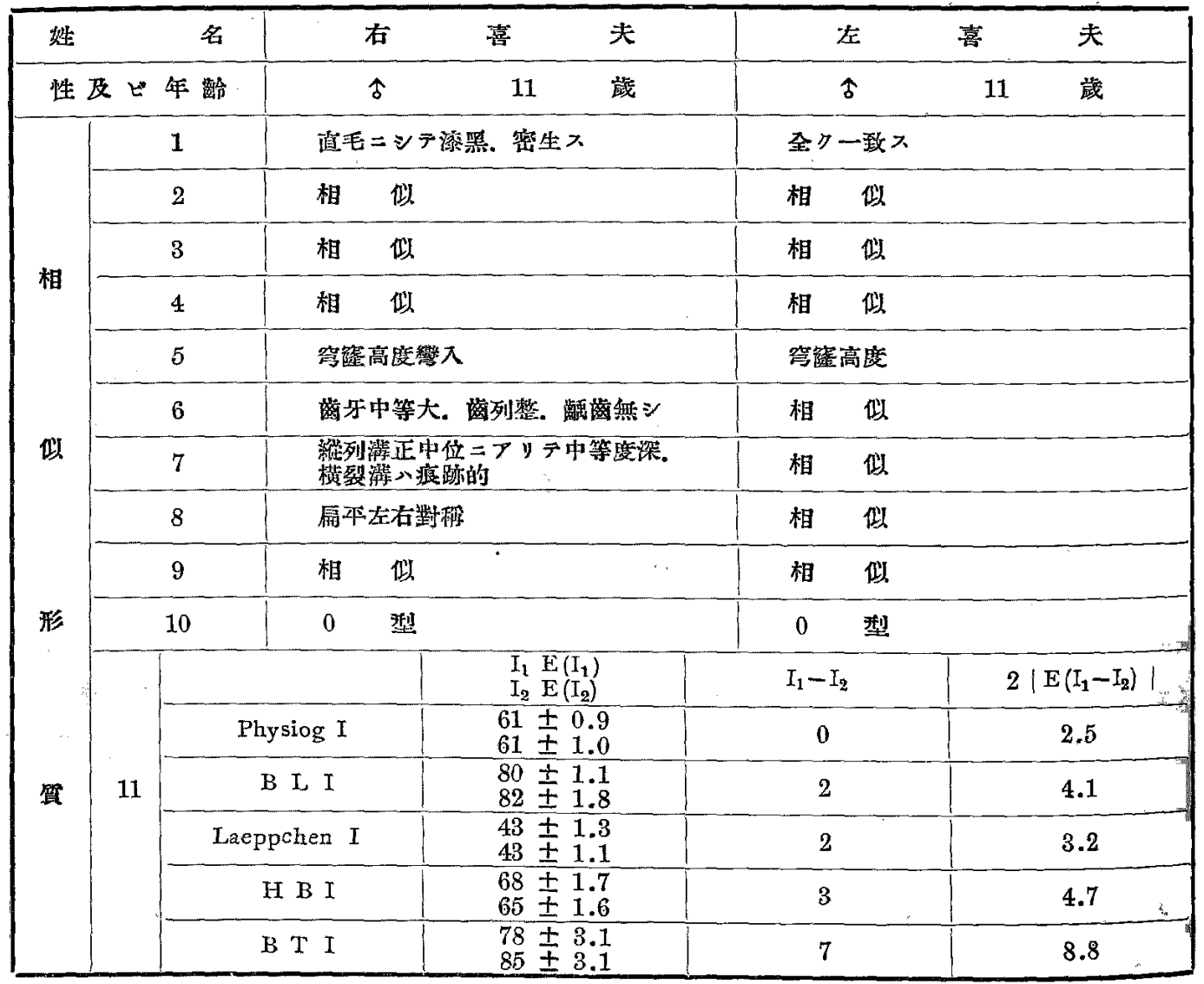




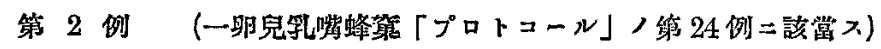

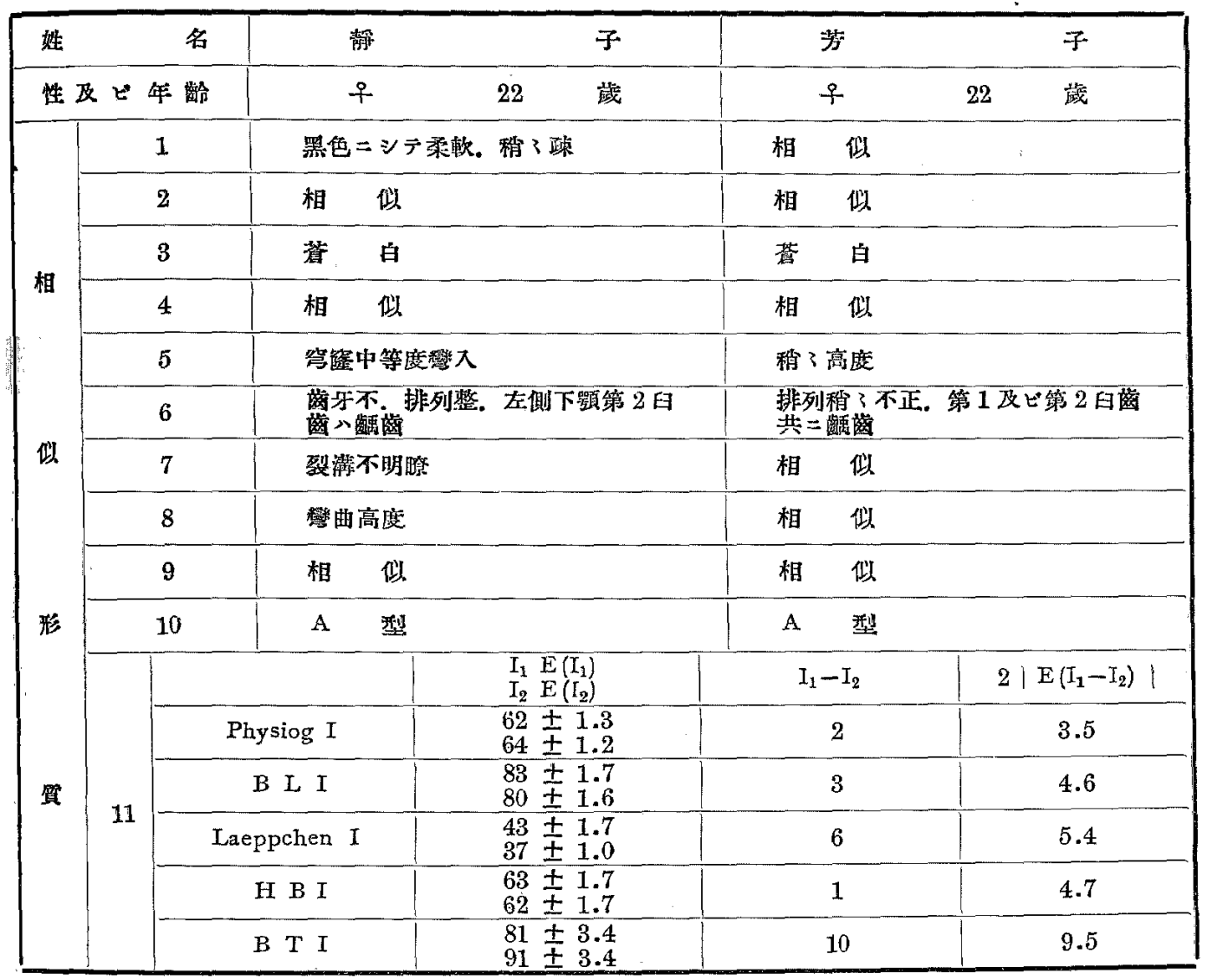

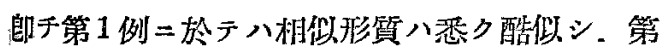
2 例=於テ，第 6 相似形買及ビ第 11 相似形質

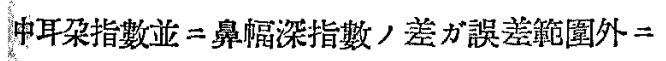
フリラ 3 形質相㒉シ。第 3 例二於テ 八全相似形 質/約 $1 / 3$ ガ類似セシニ過ギズ。而シテ全診斷 减嘖八明確 $=2$ 群 $=$ 區別サレ两群閒，移行型卜 目スベキモノハ1例モ然シ。郎チ第 1 群二於テ

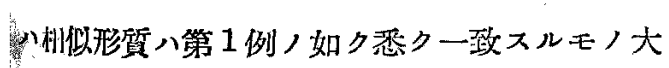
多数习占メ若シ然ラザル場合二於テモ第2例， 如ク相遠ヨ示スハ精々 3 形質二過ギズ。を二反 䍊2群二於テ八全然相似七ザルカ例人相似ス ルトー般二其頻度低クシテ全数，1/37超人 ルコト製ク．且ツ相似散發性ニシテ一貫セル形
式ア缺キ全ク「モザイク」彇アナスコト第3例 二見ルガ如シ。然モSiemens，確認セシ如ク 第 1 群二於テ八毛竪，色澤形状. 眼，色. 皮䖒

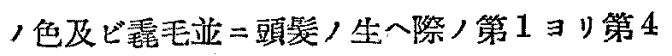
二至ル4 㰷筫八常=完全二一致シ 第 2 群二於 テハ常二著シク相違セリ。之等ノ所見ヨリ容易

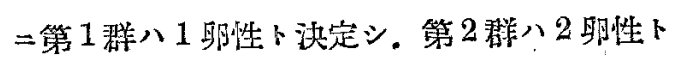
診皪シ得タリ。即ヂー卵兒ハ25 組ニシテ二卵 兒八16 組ナリ。

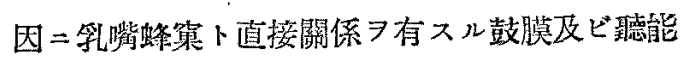
二就テ八特二精密二檢查セシガ。一卵兒中唯 1 組二於テ異常（其詳細八後逝ス）アリシノ $i=$ シテ他八渠ク正常ナリキ。

\section{$11-85$}


第 3 例 (二卵兒乳嘴蜂策「プロトコール」ノ第 14 例二該當ス)

\begin{tabular}{|c|c|c|c|c|c|c|c|}
\hline \multicolumn{2}{|c|}{ 姓 } & 名 & 淁 & & 江 & 昰 & 江 \\
\hline \multicolumn{3}{|c|}{ 性及ビ年路 } & 우 & 15 & 歲 & 우 & 15 \\
\hline \multirow{5}{*}{ 相 } & & . & \multicolumn{3}{|c|}{ 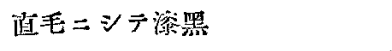 } & \multicolumn{2}{|c|}{ 㨁毛ナルモ褐色／色調篦明 } \\
\hline & & & \multicolumn{3}{|c|}{ 筧白色 } & \multicolumn{2}{|c|}{ 黑/色調强シ } \\
\hline & & ; & \multicolumn{3}{|c|}{ 黄白色 } & \multicolumn{2}{|c|}{ 蘶 白 } \\
\hline & & 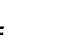 & \multicolumn{3}{|c|}{ 非相似 } & \multicolumn{2}{|c|}{ 非相 似 } \\
\hline & & & \multicolumn{3}{|c|}{ 穹隊輕度彎入 } & \multicolumn{2}{|c|}{ 相供 } \\
\hline \multirow{4}{*}{ 似 } & & ; & \multicolumn{3}{|c|}{ 圈第中等大. 排列著シク不正 } & \multicolumn{2}{|c|}{ 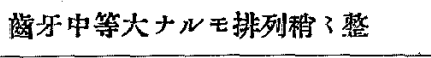 } \\
\hline & & & \multicolumn{3}{|c|}{ 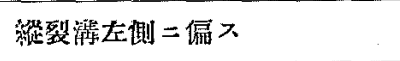 } & \multicolumn{2}{|c|}{ 相 似 } \\
\hline & & 3 & \multicolumn{3}{|c|}{ 㜻曲高弪ニシテ媵小 } & \multicolumn{2}{|c|}{ 晶平ニシテ愿シ } \\
\hline & & 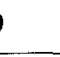 & \multicolumn{3}{|c|}{ 非相似 } & \multicolumn{2}{|c|}{ 韭相 似 } \\
\hline \multirow[t]{3}{*}{ 形 } & & & \multicolumn{3}{|c|}{0 型 } & \multicolumn{2}{|c|}{0 型 } \\
\hline & \multirow{6}{*}{11} & & & & & $\mathrm{I}_{1}-\mathrm{I}_{2}$ & $2\left|E\left(I_{1}-I_{2}\right)\right|$ \\
\hline & & & & & & 7 & 5.0 \\
\hline \multirow[t]{4}{*}{ 筧 } & & & L I & $\begin{array}{l}86 \\
77 \\
\end{array}$ & & 9 & 6.6 \\
\hline & & & hen I & $\begin{array}{l}44 \\
42 \\
\end{array}$ & & 2 & 3.8 \\
\hline & & & & & & 6 & 4.8 \\
\hline & & & $\mathrm{T} \mathrm{I}$ & & & 3 & 9 \\
\hline
\end{tabular}

扱テ 斯クシテ喰䟷シタルー卵兒 25 組二於タ

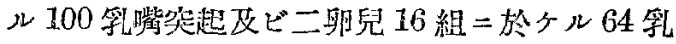
嘴等起ノ「レ」所晃心次ノ如シ。

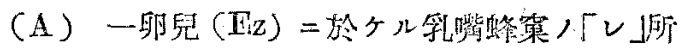
見。

\section{第一例 우우 5 歲。}

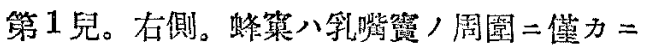
發育スルノi。其間壁八肥厚ス。S字算八强っ

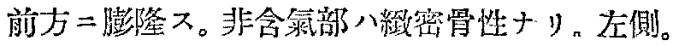

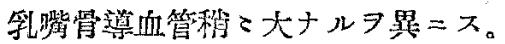

第 2 兒。右側。第 1 兒, 右側二全ク一㘧ス。 左侧。第 1 罗 左側二全ク一致大。

第三例 今令 8 歲。

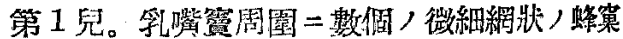
タ認メルノミニシテ，他ノ部ハ一樣二板㜔性骨

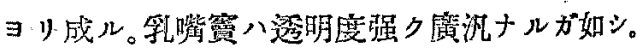

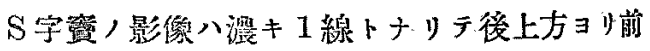
下方 $=$ 走儿。

第 2 兒。右侧八第 1 罗二一致不。左側。右側

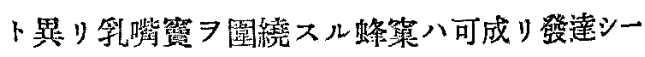
部八 $\mathrm{S}$ 字䍃，前螕=達ス。小細胞性ニシテ間壁 八肥厚ス。S字簤八前方二偏移ス。

\section{第三倒令余 8 歲。}

第1兒。网側其蜂䆬，登育著シク不良=シ テ。唯乳嘴䔰フ中心トシテ稍、廣クかナル䗋策 不規则 =笅在ス。非合氣部心緻密骨性ニジ含 


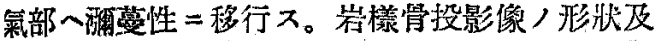
と强ク膨出セルミ字管像等左右全ク一致ス。唯 乳嘴骨導血管稍こ存側 =於テ大ナルノ

第 2 兒。丽側共全方第 1 兒 $=$ 一致ス。

第四例 +早早 9 歲。

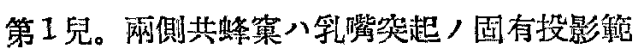
圍习鏵カニ越へ. 小細胞性ニシテ間壁中等度厚 ナルモ規則正シキ排列 稍不明瞭ナり。

第2 兒。左右共發育正常域二蓝セズ。小細胞 性ニシテ 間壁厚ク．排列稍 $、$ 統一 $\rightarrow$ 缺ク。 字簤八中等度二前方人沜移ス。

第五例 우우 10 歲。

第 1 兒。兩側共䗋䆩八乳嘴笑起，固有投影範 圍习可成り越へ，發育徒良ナリ。中細胞性，間 壁中等度厚. 規則正シク排列ス。 $\mathrm{S}$ 字笻, 像八 辛ウジテ認メ得ルノえ。

第 2 兒。䗋菓系八左右共全第 1 兒二一致 x。

\section{第六例 \&早 10 歲。}

第 1 兒。网側共䗋秋，發育佳良ニシテ全ク乳 嘴突把，固有投影籍園 7 充ス。中細胞性=シテ 閒壁韭薄. 規則正シク排列ス。 $\mathrm{S}$ 字䈯，像八上 㮏部二於テ淽カ二現ハル、，。

第 2 兒。雨側共第 1 兒二媅ダ醌似ス。但シ $\mathrm{S}$

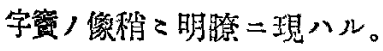

\section{第七例 令 11 歲。}

第1 兒。左右共二籍園正常ナルモ。一般二大 蜂笨性ニシテ，閒壁菲纎，排列統一 7 䊽ク。 $\mathrm{S}$

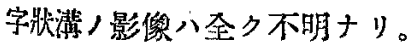

第 2兒。网側共第 1 兒二極メテ類似ス。但シ 排列八前者ヨリモ㭼 $く$ 不規則ナリ。

第入列 今。 12 眥。
第 1 見。网側共乳嘴突迪八板陪性骨 $コ$ 成ル

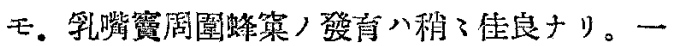
樣二小細胞性，間壁厚シ。 $\mathrm{S}$ 字筑, 前緗線八明 瞭二描出サル。

第 2 兒。左右共二發音八正常域二達セズシ テ. 尖端ニ八板障橴，非含挡部 7 存ス。大細胞 性ニシテ。隔壁厚ク 排列不規則ナリ。 $\mathrm{S}$ 字虽 ，影像明膫ナリ。

\section{第九例 合令 12 歲。}

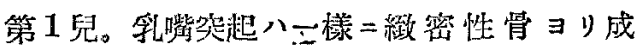

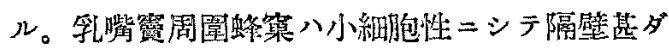

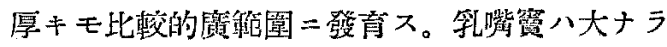
ザルガ如シ。S字管像明膫。

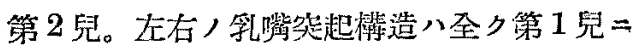
一致大。

第十例 우오 12 歯。

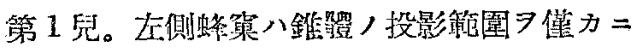
越二。小䗋稚悴ニシテ，間壁中等度厚．排列規 則的ナリ，尖䁲へ含氮セズシテ板隐性ナリ。S 字贺像明膫二現ハレ：前方二偏移ス。左倒。發

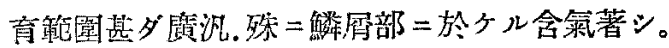

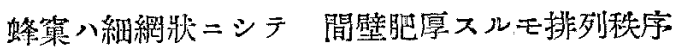
正シ。S字盗影像不明。

第 2 兒。右侧。第 1 兒, 左側二一致不。左側。 發者度秒了劣ルモ。棰成態八右側及ビ第 1 兒 左側二酷似ス。但シ $\mathrm{S}$ 字簤 影像八略、明瞭。

第十一例令令 13 縓。

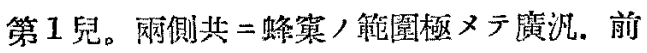

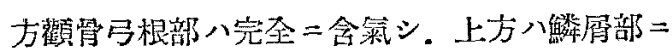
深ク侵大シ，後方八後頭乳嘴縫際二遙ス。中細 胞性ニシテ排列規則的，間壁菲灌ナリ。S 字䆓

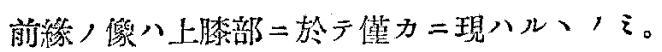

第 2 兒。两側共二第 1 兒二酷似ス。 


\section{第十二例 令古 13 歲。}

第 1 兒。蜂箱，籁園極メラ廣沉、顧骨根部. 䚬屑部。隅的部等二モ發澾著シク．殊二後方八 乳嘴後頭縫際二迄澾ス。大細狍性ニシテ. 間壁

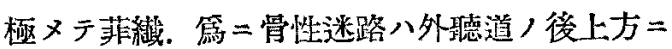
「コントラスト」强キ一塊/影像トシテ浮ビ出 ジ。蜂案八遠心性二濑次墦大シ規則正シキ排列 タナス。S字䆬像八枉ク認メ得ズ。

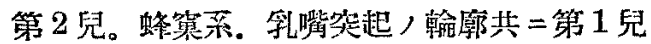
二酷似又。

\section{第十三例 今客 14 藏。}

第 1 兒。右側。乳嘴突起八爾側共二全ク䗋窗

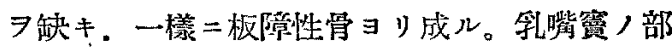

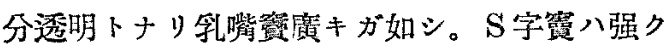
膨出ス。

第 2 兒。䗋案八略々岩榡骨，圆有投影範圍 充ス。小蜂䆩性ニシテ排列不規則，閒壁厚シ。 $\mathrm{S}$ 字竇前綾，像鮮明ナリ。

\section{第十四例 우우 14 歲。}

第 1 兒。兩側共二䗋窠, 發青甚ダ良好ニシラ

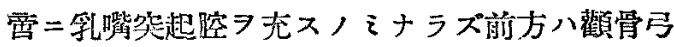
根部二及ビ．上方八䚬展部=深ク侵入シ，又謁 解部及ビ後 $\mathrm{S}$ 字空部二於テモ䗋穼, 發育著シ。 中細胞性ニシテ 閒壁中等度厚. 敩緣ニ行クニ 從ツテ次第二大サョ增シ。規則正シク排列ス。

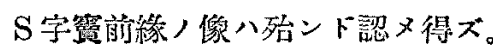

第 2 兒。䗋䇛, 棈造八网側共殆ンド全ク第 1 兒二一致シ，唯 $\mathrm{S}$ 字䉪，像稍 スルノミ。

\section{第十五例 우우 14 歲。}

第 1 兒。右側。蜂窂八錐體，固有投影筑園 7 充シ 份ホ䚬居部及ビ顴骨弓根部ニモ及ブ。侣 ホ特暴ナルハ尖端二於テ1個，著シク大ナル蛒
窧ヨ存スルコトナリ。一般ニ小細胞性ニシテ.

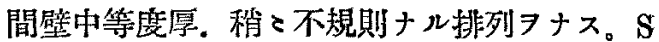
字竇八强ク前方二轉移ス。左側。範圍正常。一 樣ニ小細胞性ニシテ，唯邊緗䗋笨ノミ急激二增 大ス。間壁中等度厚. 排列稍 3 不規則ナリ。S 字䨳, 影像习認メ得ズ。

第 2 兒。右側。第 1 兒ノ右側二極メテ酷似シ 称二終末䗋菑，形狀＝於テ然り。左側。第 1 兒 ，左側二甚ダ類似ス。

\section{第十六例 우우 15 歲。}

第 1 兒。兩側共全ク所謂正常蜂巢 / 像 7 呈 ス。師チ全乳嘴突起腔八完全 $=$ 含氣サレ，中細 胞性ニシテ問壁菲薄。極メテ規則正シク排列ス。 $\mathrm{S}$ 字霣, 前縁線ハ不明膫ナリ。

第 2 兒。兩側共 =第 1 兒二酷似 ス。唯終末䗋 菓稍く大ナリ。

\section{第十七例 今。 10 歲。}

第 1 兒。䒽側共發育度正常。中細胞性ニシテ 間壁菲溥. 排列正規ナリ。 $\mathrm{S}$ 字寶，影缘八僅力 二侅又得。

第 2 兒。右惻八第 1 兒=酷似ス。左側乳嘴究 起ノ大牛八維密骨ヨ门成り。蜂案ハ主トシテ乳

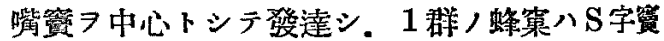
，前緗及ビ下方八乳嘴截根附近迄達ス。小細胞

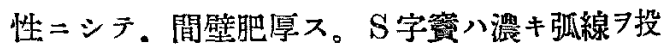
射ス。

\section{第十八例 우우 15 歲。}

第 1 兒。乳嘴突起八兩側共維密骨性ニシテ：

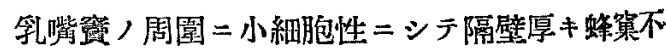

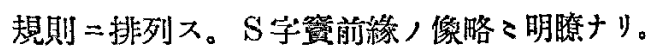

第 2 兒。雨側共發育範圍正常域二達セズ。小 細胞性ニシテ排列稍 3 不規則，間壁八肥厚。 $\mathrm{S}$

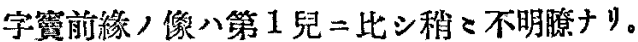


第十九例 今金 15 龇。

第 1 兒。右側。發育展略、正常。小細胞性= シテ.間壁肥厚スルモ. 秩序正シキ排列アナス。

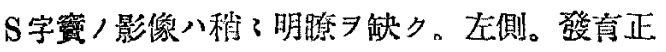
常域二澾七ズ。尖端部八念氮セズシラ゙緻密骨性 ナリ。爾鉒ノ排成態八右側二一致ス。

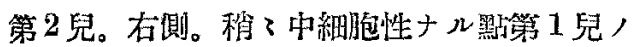
右側卜異ナルノ 示類似ス。

\section{第二十例 우 16 歲。}

第 1 兒。兩側共䗋菓八乳嘴突起腔 7 全り它 =至ラズ。S字跎，後方二緻密骨性，非含氮部 7 殘ス。中細胞性，間壁中等度厚，大䯤規則正

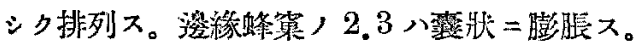

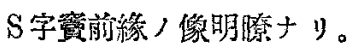

第 2 兒。䗋策，發育籍園八第 1 兒二比シテ稍 稍劣り咯

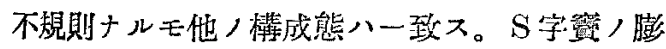
隆中等度。

\section{第二十一例 今㑒 16 歲。}

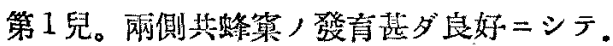

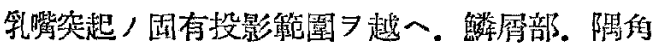
部。後 $\mathrm{S}$ 字筼部ニ及ブ、蛒策ハ中細胞性ニシテ

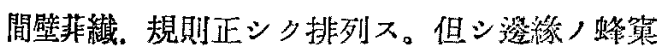
八稍 膨隆入。

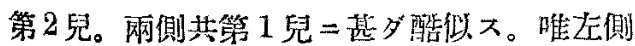
二於天鳞屑部䗋笨，發肖倀ル。

\section{第二十二例令 17 瓷。}

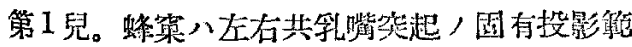

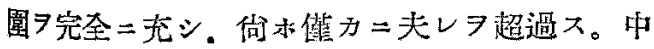
緗胞性ニシテ 間壁中等度厚. 排列規則正シキ

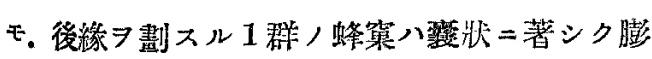

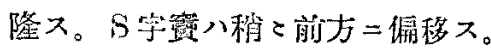

第 2 兒。网側路案系 八第 1 兒二極メテ酷似

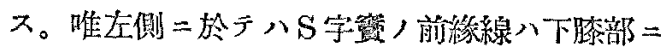
於于稍七不明膫ナリ。

第二十三例 우우 12 筬。

第 1 兒。右侧。䗋栔八略

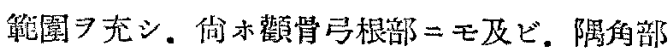
ニニ筂達ス。小細胞性ニシテ間壁中等度厚ナル モ. 排列略 規則的ナリ。非含氣部八板障性二 シテ含氣部卜，間二尖銃ナル境界ア劃ス。S字

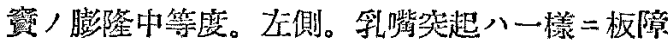

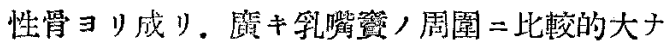

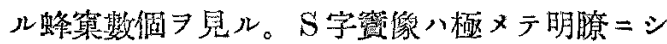
テ膨隆モ亦著シ。

第2兒。右側。第1兒, 左侧二芼ク一致ス。 圭側。第 1 兒/右側二芼ク一致ス。

第二十四例 우우 22 䶕。

第 1 兒。兩側䗋䉾，發去度正常ナルモ，顴骨

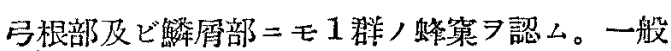

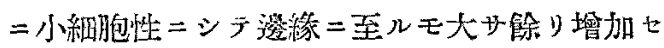
ズ。聞壁中等度掌，排列秒 、不規則ナリ。 $\mathrm{S}$ 字 簕像八全ク認メ得ズ。

第 2 兒。庆存共第 1 兒二全ク一致不。

\section{第二十五例 合占 23 歲。}

第 1 兒。䗋穿八略 ル。䗋策性ニシテ間壁部厚シ. 排列統一 7 缺 ク，非含氮部八緻密骨性ナリ。S 宇筧八可成强 ク前方二迫ル。乳嘴骨学血管八左側二於テ强大 ナリ。

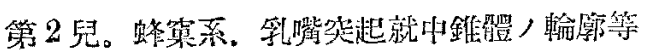
第1兒二極メラ類似ス。但シ乳嘴骨等血管ハ之上 側二於テ强大ナリ。

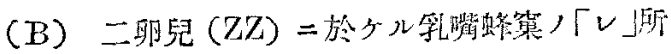


胃。

\section{第一例令全 7 画。}

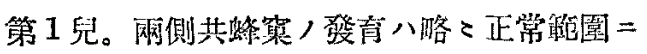
匹敵スルモモ，小細胞性ニシテ．間壁厚ク，排列 不規則ナり。S 字露ノ前緗線ハ下膫部二於テ離 斷サル。

第 2 兒。右側。發育卧八正常+ルモ，第 1 兒 卜買リ大細胞性ニシテ，閒壁菲腹。排列又規則

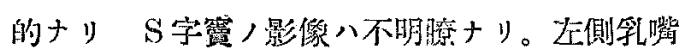

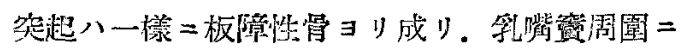

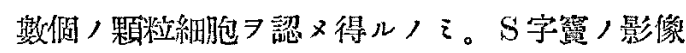
八極メテ明㹉ナリ。

\section{第二例 今金 8 歳。}

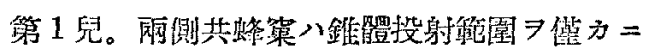
超過ス。中細胞性ニシテ閒壁中等度厚. 排列規

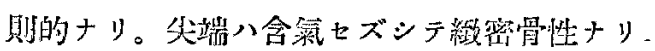

\section{$\mathrm{S}$ 字窑影像，浱度中等度。}

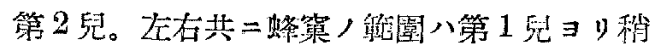
秒覽シ。小細胞性ニシテ 間壁肥厚シ，排列続 一タ领 グ。S字露, 後牛部及ビ尖端二非含氣部

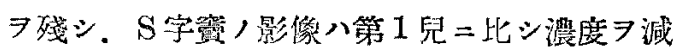
ズ。

\section{第三例 우우 9 歲。}

第 1 兒。右側，佂園正裳，中細胞性=シテ

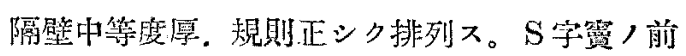
縁線八上䅎部二於テ認メラル、ノ $i 。$

左側。小細狍性ニシテ排列不規則ナル㩏右側 卜相違ス。

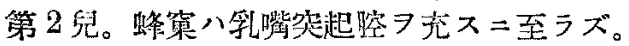

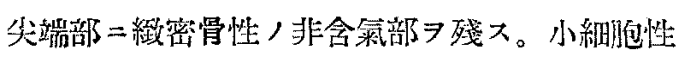

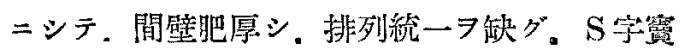
八前緗八浱キ1線トナリテ後上方ヨリ前下方二

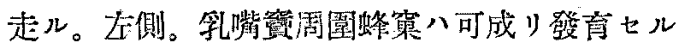

モ大部分八念沗セズシテ緻密骨性ナリ。S字翼 八影像蝔ダ明隌。

第四例 令令 9 歳。

第 1 兒。网側空發音正常域=及バザルコト可 成り㵆シ。小細胞性ニシテ間壁厚ク．排列不規 則ナリ。S等簕入强ク前方二膨出ス。

第 2 兒。發有戔及ビ排列 =於テノミ第 1 兒= 類似 ス。

第五例 우우 10 歲。

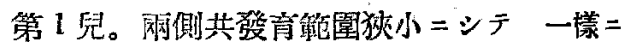

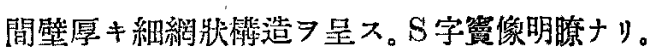

第 2 兒。网側共乳嘴桑起”大部分板障骨 $\exists$ ? 成り乳嘴管周圍＝1群ノ顆粘状䗋窂 7 見ル。乳

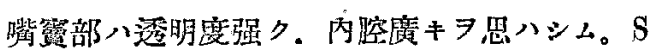

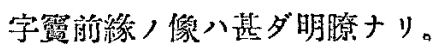

第六例 우우 30 歲。

第 1 兒。网側共蜂巢八乳嘴突起，圆有投影笠 園ヨ充シ．小細胞性ニシテ閒壁厚ク 不規則二 排列ス。 $\mathrm{S}$ 字簤 像八秒 3 明蹽 7 缺ら゙;

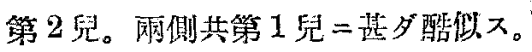

第七例 우 10 筬。

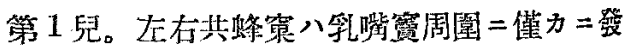
肖スルノミニシテ 大部分絰密骨ヨリ成心。

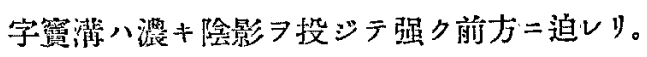

第 2 兒。网側共第 1 兒二酷似スルモ．錐體上

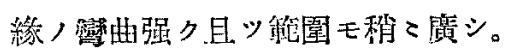

\section{第入例 令令 11 歲。}

第 1 兒。网側共蜂僯, 發音椹ダ良好ニシテ

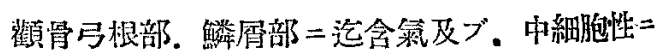
シテ 閒壁菲繊. 規則正シキ排列タナス。S字 翼ノ影兴八不㕫嘹ナり。

第2 兒。网側基䗋䶂系模成態八第 1 兒卜一致

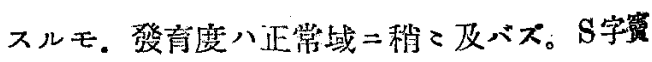


八前線線ハ在側二於テ路了昉カナリ。

茅九例 今令 13 歲。

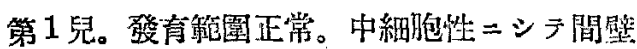
中等度厚，秩序正シク排列ス。 $\mathrm{S}$ 字賞像八下膝 部二於テ消失ス。

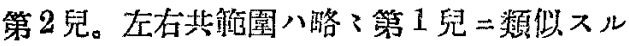

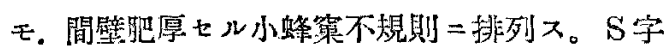
䈯, 像ハ比較的明瞭ナリ。

第十甽 우우 13 踔。

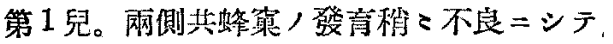
尖端ニハ非含寀部 壁稍く肥厚スルモ。㭠序アル排列フナス。S字 筑影像明嘹ナり。

第 2 兒。發青度八第 1 兒二一致スルモ。棈成

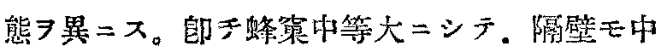

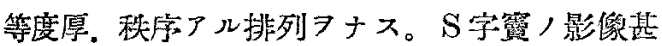
ダ明䏦ナリ。

\section{第十一例 우우 13 䶕。}

第 1 兒。网側共發育筑園極 テ琵况。中細胞

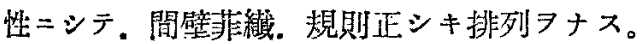
S字簤ノ影像ハ努ンド認ムル能ハズ。

第 2 兒。左右共間壁中等度厚ナル外第 1 罗二 酷似入。

\section{第十二例 今。 14 藏。}

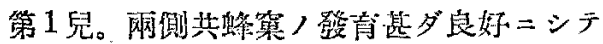

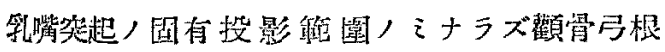

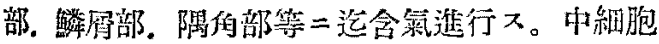

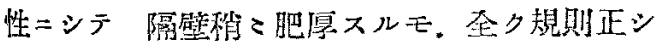

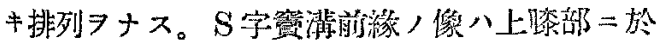
テ淽カニ現ハル、ノ゙。

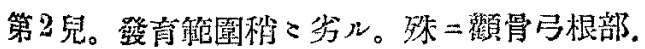

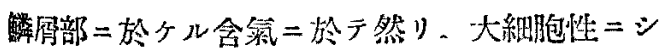

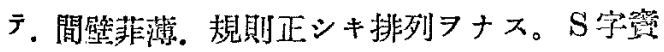

像心䀡こ明膫ナり。

\section{第十三例 今。 15 歲。}

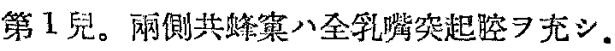
何ホ少シクシンフ超渦シ。間壁中等度厚ナル中

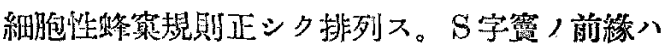
可成り漫キ影傻ア投射ス。

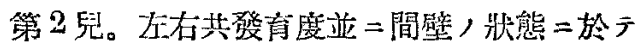
八第 1 罗二類似スル王、䗋案小小細胞性ニシテ、

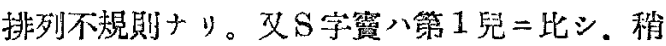

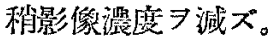

\section{第十四例 우우 15 紫。}

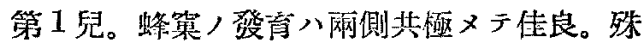
二媵方八乳㗪後頭濑擦二迄迫ラントス。中細胞 性ニシテ 閵壁中等麻厚．排列正規的ナリ。S

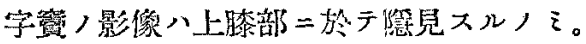

第 2 兒。在側。排列及ビ細胞ノ大サ八第 1 兒

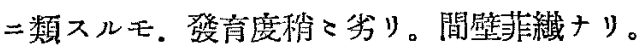

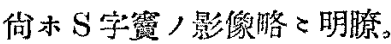

左側。㫏圍正常。中細胞性ニシテ 間壁中等

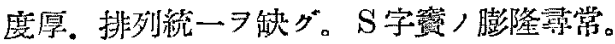

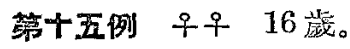

第 1 兒。右側。䗋策, 發音度峈こ正常。中細 胞性ニシテ，閒壁中等度厚ナルモ等条案規則正シ ク排列ス。但シ乳嘴突起尖端ニハ1個ノ大ナル

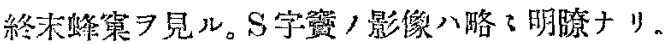

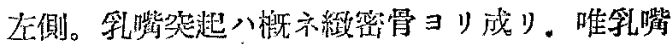

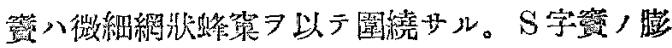
隆著明ナり。

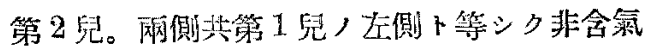

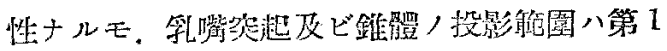

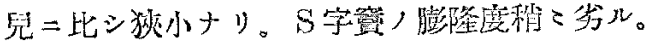

管十然例 令 18 盐。

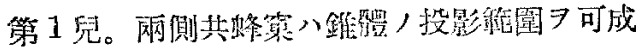


リ超過ス。間壁肥厚七ル小細胞性䗋窴不規則二 排列ス。尖端及ビ $\mathrm{S}$ 字簤後半八会氣セズシテ維

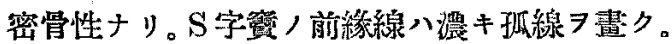

第 2 兒。右側。排列並=間壁，狀態等八第 1

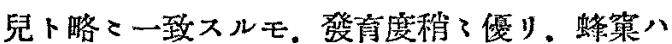
概亦中細胞性ナリ、左側。發育度正常。中細胞 性ニシテ．閶壁中等度厚．排列規則的ナリ。S 字害影像八略? 明瞭。

\section{第二節 總括並二考案}

既二第 1 章二述ペシガ如ク，乳嘴蜂集，遺售 關係解明 =䨋りテハ特殊形翼ノ存否习追究スル ニ非ズシテ．專ラ双生兒各組間二於ケル相似乃
至非相似人程度习知ラントスルモノナリ。余八 此目的ノ下二前記ノ一邲兒 25 組二於ケル100 側乳踭蜂窠及ビ二卵兒 16 組 $=$ 於ケル 64 側乳嘴 䗋策ノ「レ」所見习數項二分チテ篗察シ Albrecht, Leicher, Schwarz / 成績卜對照批制スル 卜共 $=$ Wittmaack 一派, 外因說 7 再檢討七ン トス。

（1）一卵兒及ビ二卵兒二於分儿檄括的相似度 , 比較。

先ヅ通覽二便ナラシメンガ䉆メ，第 1 章=詳 述七シ「レ」所見 7 余ノ表現法 7 以テ示七バ第 1 表及ビ第 2 表ノ如シ。

第 1 表

\begin{tabular}{|c|c|c|c|c|c|c|c|}
\hline \multirow{2}{*}{ 番 } & \multirow{2}{*}{ 號 } & & 乳 & 嘴 & 策 & 潒 & \\
\hline & & 右 & & 側 & \multicolumn{2}{|l|}{ 左. } & 侧 \\
\hline $\mathrm{EZ}$ & $\frac{1}{5} \mathrm{Ij}$ & $\begin{array}{l}\mathrm{IV} \\
\mathrm{IV}\end{array}$ & $\begin{array}{l}\mathbf{K} \\
\mathbf{K}\end{array}$ & $\begin{array}{l}(\mathrm{hg}) \\
(\mathrm{hg})\end{array}$ & $\begin{array}{l}\mathbb{N} \\
\mathbb{I N}\end{array}$ & $\begin{array}{l}\mathrm{K} \\
\mathrm{K}\end{array}$ & $\begin{array}{l}\text { (hg) } \\
\text { (hg) }\end{array}$ \\
\hline $\mathrm{EZZ}$ & $\begin{array}{ll}2 & \\
8 & \mathrm{Lj} . \\
\end{array}$ & $\begin{array}{l}\text { IV } \\
\text { IV }\end{array}$ & $\begin{array}{l}\mathrm{dp} \\
\mathrm{dp}\end{array}$ & $\begin{array}{l}\text { (hg) } \\
(\mathrm{hg})\end{array}$ & $\begin{array}{l}\text { IN } \\
\text { IV }\end{array}$ & $\begin{array}{r}\mathrm{dp} \\
\mathrm{c \gamma d \textrm {dp }}\end{array}$ & $\begin{array}{l}(\mathrm{hg}) \\
(\mathrm{hg})\end{array}$ \\
\hline$E Z$ & $\begin{array}{ll}3 & \mathrm{Lj} . \\
\end{array}$ & $\frac{\pi}{1 V}$ & $\begin{array}{l}2 c \beta K \\
2 \mathrm{c} \beta \mathrm{K}\end{array}$ & $\begin{array}{l}(\mathrm{hg}) \\
(\mathrm{hg})\end{array}$ & $\begin{array}{l}\mathbb{N} \\
\mathbb{N}\end{array}$ & $\begin{array}{l}2 c \beta K \\
2 c \beta K \\
\end{array}$ & $\begin{array}{l}\text { (hg) } \\
(\mathrm{hg})\end{array}$ \\
\hline$\overline{E Z}$ & $\begin{array}{l}4 \\
9 \mathrm{Lj}\end{array}$ & III & $\begin{array}{l}1 c \beta \\
2 c \gamma\end{array}$ & $\begin{array}{r}(\mathrm{gg}) \\
(\mathrm{mg})\end{array}$ & III & $\begin{array}{l}1 c \beta \\
2 c \gamma\end{array}$ & $\begin{array}{r}(\mathrm{gg}) \\
(\mathrm{mg})\end{array}$ \\
\hline $\mathrm{EZZ}$ & $\begin{array}{r}5 \\
10 \mathrm{Lj} .\end{array}$ & I & $\begin{array}{l}1 \mathrm{~b} \beta \\
1 \mathrm{~b} \beta\end{array}$ & $\begin{array}{l}(\mathrm{gg}) \\
(\mathrm{gg})\end{array}$ & $\begin{array}{l}I \\
I\end{array}$ & $\begin{array}{l}1 \mathrm{~b} \bar{\beta} \\
1 \mathrm{~b} \beta\end{array}$ & $\begin{array}{l}(\mathrm{gg}) \\
\text { (gg) }\end{array}$ \\
\hline $\mathrm{EZ}$ & $\begin{array}{r}6 \\
10 \mathrm{Lj} .\end{array}$ & III & $\begin{array}{l}1 \mathrm{~b} \alpha \\
1 \mathrm{~b} \alpha\end{array}$ & $\begin{array}{l}\text { (gg) } \\
\text { (gg) }\end{array}$ & III & $\begin{array}{l}1 \mathrm{~b} x \\
1 \mathrm{bx}\end{array}$ & $\begin{array}{l}\text { (gg) } \\
\text { (gg) }\end{array}$ \\
\hline $\mathrm{EZ}$ & ${ }^{7} \mathrm{Lj}$. & III & $\begin{array}{l}2 a \alpha \\
2 a \alpha\end{array}$ & $\begin{array}{l}(\mathrm{gg}) \\
(\mathrm{gg})\end{array}$ & III & $\begin{array}{l}2 a^{\alpha} \\
2 a^{\alpha}\end{array}$ & $\begin{array}{l}(\mathrm{gg}) \\
(\mathrm{gg})\end{array}$ \\
\hline $\mathrm{EZ}$ & $\begin{array}{c}8 \\
12 \mathrm{Lj} .\end{array}$ & III & $\begin{array}{l}\text { cүdp } \\
2 \text { bydp }\end{array}$ & $\begin{array}{l}\text { (hg) } \\
\text { (hg) }\end{array}$ & III & $\begin{array}{l}\text { crdp } \\
2 \text { bүdp }\end{array}$ & $\begin{array}{l}(\mathrm{hg}) \\
(\mathrm{mg})\end{array}$ \\
\hline$\overline{E Z}$ & $\begin{array}{rl}9 & \\
12 & \mathrm{Lj} .\end{array}$ & $\frac{N}{N}$ & $\begin{array}{l}c \gamma K \\
c \gamma K\end{array}$ & $\begin{array}{l}\text { (hg) } \\
\text { (hg) }\end{array}$ & $\frac{1 N}{\mathbb{N}}$ & $\begin{array}{l}c_{\gamma} \bar{K} \\
c_{\gamma} \mathrm{K}\end{array}$ & $\begin{array}{l}\text { (hg) } \\
\text { (hg) }\end{array}$ \\
\hline$\overline{\mathrm{EZ}}$ & $\begin{array}{l}10 \mathrm{Ij} . \\
12 \mathrm{I}\end{array}$ & III & $\begin{array}{l}1 c \beta d p \\
1 c \gamma\end{array}$ & $\begin{array}{c}(\mathrm{mg}) \\
(\mathrm{gg})\end{array}$ & I & $\begin{array}{l}1 c \gamma \\
1 c \gamma\end{array}$ & $\begin{array}{l}(\mathrm{gg}) \\
(\mathrm{gg})\end{array}$ \\
\hline$E Z$ & $11 \mathrm{Lj}$. & I & $\begin{array}{l}1 \bar{b} \alpha \\
1 b \alpha\end{array}$ & $\begin{array}{l}\text { (gg) } \\
\text { (gg) }\end{array}$ & $\begin{array}{l}\text { I } \\
\text { I }\end{array}$ & $\begin{array}{l}1 \mathrm{~b} \alpha \\
1 \mathrm{~b} \alpha\end{array}$ & $\begin{array}{l}(\mathrm{gg}) \\
(\mathrm{gg})\end{array}$ \\
\hline$\overline{E Z}$ & $\begin{array}{ll}12 \\
13 \mathrm{Lj} .\end{array}$ & I & $\begin{array}{l}\text { 1 } a \alpha \\
1 a \alpha\end{array}$ & $\begin{array}{l}\text { (gg) } \\
\text { (gg) }\end{array}$ & $\begin{array}{l}I \\
I\end{array}$ & $\begin{array}{l}1 \mathrm{a} \alpha \\
1 \mathrm{a \alpha}\end{array}$ & $\begin{array}{l}(\mathrm{gg}) \\
(\mathrm{gg})\end{array}$ \\
\hline$\overline{E Z}$ & $\begin{array}{l}13 \\
14 \mathrm{Lj} .\end{array}$ & II & $\begin{array}{r}K \\
2 c \gamma\end{array}$ & $\begin{array}{l}(\mathrm{hg}) \\
(\mathrm{hg})\end{array}$ & $\begin{array}{l}\text { IV } \\
\text { III }\end{array}$ & $\begin{array}{r}K \\
2 \mathrm{cY}\end{array}$ & $\begin{array}{c}(\mathrm{hg}) \\
(\mathrm{mg})\end{array}$ \\
\hline EZ & $\begin{array}{l}14 \mathrm{Lj} . \\
14 \mathrm{~L}\end{array}$ & $\begin{array}{l}\text { I } \\
\text { I }\end{array}$ & $\begin{array}{l}1 \mathrm{~b} \beta \\
1 \mathrm{~b} \beta\end{array}$ & $\begin{array}{l}(\mathrm{gg}) \\
(\mathrm{gg})\end{array}$ & $\begin{array}{l}I \\
I\end{array}$ & $\begin{array}{l}1 \mathrm{~b} \beta \\
1 \mathrm{~b} \beta\end{array}$ & $\begin{array}{l}\mathrm{gg}) \\
\text { (gg) }\end{array}$ \\
\hline EZ & $\begin{array}{l}15 \\
14 \mathrm{Lj} .\end{array}$ & $\begin{array}{l}\text { III-II } \\
\text { III }- \text { II }\end{array}$ & $\begin{array}{l}2 c \beta \\
2 c \beta\end{array}$ & $\begin{array}{l}\text { (gg) } \\
\text { (gg) }\end{array}$ & III & $\begin{array}{l}2 c \beta \\
2 c \beta\end{array}$ & $\begin{array}{l}(\mathrm{gg}) \\
(\mathrm{gg})\end{array}$ \\
\hline EZ & $\begin{array}{l}16 \mathrm{Ij} . \\
15\end{array}$ & II & $\begin{array}{l}1 \mathrm{~b} \alpha \\
1 \mathrm{~b} \alpha\end{array}$ & $\begin{array}{l}(\mathrm{gg}) \\
(\mathrm{gg})\end{array}$ & II & $\begin{array}{l}1 b \alpha \\
1 b \alpha\end{array}$ & $\begin{array}{l}\text { (gg) } \\
\text { (gg) }\end{array}$ \\
\hline $\mathrm{EZ}$ & $\begin{array}{l}17 \\
15 \mathrm{Lj} .\end{array}$ & II & $\begin{array}{l}1 \mathrm{~b} \alpha \\
1 \mathrm{~b} \alpha\end{array}$ & $\begin{array}{l}\text { (gg) } \\
\text { (gg) }\end{array}$ & II & $\frac{1}{K}^{1 \mathrm{~b} \alpha}$ & $\begin{array}{l}\text { (gg) } \\
\text { (hg) }\end{array}$ \\
\hline $\mathrm{EZ}$ & $\begin{array}{l}18 \\
15 \mathrm{Lj} .\end{array}$ & III & $\begin{array}{l}2 \mathrm{crK} \\
2 \mathrm{c \gamma K}\end{array}$ & $\begin{array}{c}(\mathrm{gg}) \\
(\mathrm{mg})\end{array}$ & $\frac{\mathrm{III}}{\mathrm{IV}}$ & $\begin{array}{l}2 \mathrm{c} \bar{K} \\
2 \mathrm{c} \gamma \mathrm{K}\end{array}$ & $\begin{array}{l}\text { (gg) } \\
\text { (gg) }\end{array}$ \\
\hline
\end{tabular}




\begin{tabular}{|c|c|c|c|c|c|c|c|}
\hline $\mathrm{EZ}$ & $\begin{array}{l}19 \\
15 \mathrm{Lj} .\end{array}$ & II & $\begin{array}{l}1 \mathrm{c} \gamma \\
1 \mathrm{by}\end{array}$ & $\begin{array}{l}\text { (gg) } \\
\text { (gg) }\end{array}$ & $\begin{array}{l}\text { III } \\
\text { II }\end{array}$ & $\begin{array}{l}1 \mathrm{c} \gamma+\mathrm{K} \\
1 \mathrm{c} \gamma\end{array}$ & $\begin{array}{l}(\mathrm{mg}) \\
\text { (gg) }\end{array}$ \\
\hline EZ & $\begin{array}{ll}20 & \\
16 & \mathrm{Lj} .\end{array}$ & IIII - IV & $\begin{array}{l}1 \mathrm{~b} \beta \mathrm{K} \\
2 \mathrm{~b} \beta \mathrm{K} \\
\end{array}$ & $\begin{array}{l}(\mathrm{mg}) \\
(\mathrm{mg}) \\
\end{array}$ & III - IV & $\begin{array}{l}1 \mathrm{~b} \beta \mathrm{K} \\
2 \mathrm{~b} \beta \mathrm{K}\end{array}$ & $\begin{array}{l}(\mathrm{mg}) \\
(\mathrm{mg})\end{array}$ \\
\hline EZ & $\begin{array}{ll}21 \\
16 & \\
\end{array}$ & I & $\begin{array}{l}1 b x \\
1 b x\end{array}$ & $\begin{array}{l}(\mathrm{mg}) \\
(\mathrm{mg})\end{array}$ & $\frac{\mathrm{I}}{\mathrm{I}}$ & $\begin{array}{l}1 \mathrm{~b} \alpha \\
1 \mathrm{~b} \alpha\end{array}$ & $\begin{array}{l}(\mathrm{mg}) \\
(\mathrm{mg})\end{array}$ \\
\hline $\mathrm{EZ}$ & $\begin{array}{ll}22 & \\
17 & \text { L.j }\end{array}$ & $\frac{\pi}{I}$ & $\begin{array}{l}1 \mathrm{~b} \beta \\
1 \mathrm{~b} \beta\end{array}$ & $\begin{array}{l}(\mathrm{mg}) \\
(\mathrm{mg})\end{array}$ & III & $\begin{array}{l}1 \mathrm{~b} \beta \\
1 \mathrm{~b} \beta\end{array}$ & $\begin{array}{l}(\mathrm{mg}) \\
(\mathrm{mg})\end{array}$ \\
\hline $\mathrm{EZ}$ & $\begin{array}{ll}23 \\
18 \mathrm{Lj} .\end{array}$ & III & $\begin{array}{l}1 c \beta \\
d p\end{array}$ & $\begin{array}{l}(\mathrm{mg}) \\
(\mathrm{hg})\end{array}$ & III & ${ }_{1 p}^{d p} d p$ & $\begin{array}{l}(\mathrm{hg}) \\
(\mathrm{mg})\end{array}$ \\
\hline $\mathrm{EZ}$ & $\begin{array}{l}24 \\
22 \mathrm{Lj} .\end{array}$ & III & $\begin{array}{l}2 c \beta \\
2 c \beta\end{array}$ & $\begin{array}{l}\text { (mg) } \\
\text { (mg) }\end{array}$ & III & $\begin{array}{l}2 c \beta \\
2 c \beta\end{array}$ & $\begin{array}{l}(\mathrm{mg}) \\
(\mathrm{mg})\end{array}$ \\
\hline $\mathrm{EZ}$ & $\begin{array}{ll}25 & \\
23 & \mathrm{Lj} .\end{array}$ & IIII & $\begin{array}{l}2 \mathrm{c} \beta \mathrm{K} \\
2 \mathrm{c \beta K}\end{array}$ & $\begin{array}{l}\text { (hg) } \\
\text { (hg) }\end{array}$ & IIII & $\begin{array}{l}2 c \beta \bar{K} \\
2 c \beta K\end{array}$ & $\begin{array}{l}\text { (hg) } \\
\text { (hg) }\end{array}$ \\
\hline
\end{tabular}

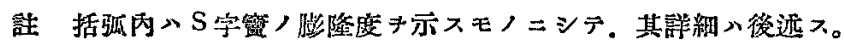

第 2 表

\begin{tabular}{|c|c|c|c|c|c|c|c|}
\hline \multirow{2}{*}{ 委 } & \multirow{2}{*}{ 號 } & & 乳 & 勓 & 蜂 & 像 & \\
\hline & & 右 & & 側 & \multicolumn{2}{|l|}{ 灰 } & 洒 \\
\hline$\overline{Z Z}$ & $7 \mathrm{Lj}$. & III & $\begin{array}{l}2 \mathrm{ct} \\
1 \mathrm{ag}\end{array}$ & $\begin{array}{l}\text { (gg) } \\
\text { (gg) }\end{array}$ & $\frac{\overline{I I}}{\mathrm{IV}}$ & $\begin{array}{l}2 \mathrm{c} \gamma \\
\mathrm{dp}\end{array}$ & $\begin{array}{l}(\mathrm{gg}) \\
(\mathrm{hg}) \\
\end{array}$ \\
\hline$\overline{\mathrm{ZZ}}$ & $\begin{array}{ll}2 \\
8 \mathrm{Lj}\end{array}$ & III & $\begin{array}{l}1 \mathrm{~b} \beta \mathrm{K} \\
2 \mathrm{c} \gamma \mathrm{K}\end{array}$ & $\begin{array}{l}(\mathrm{mg}) \\
(\mathrm{gg})\end{array}$ & III & $\begin{array}{l}1 \mathrm{~b} \beta \mathrm{K} \\
2 \mathrm{c} \gamma\end{array}$ & $\begin{array}{l}(\mathrm{mg}) \\
(\mathrm{gg})\end{array}$ \\
\hline $\mathrm{ZZ}$ & $\begin{array}{ll}3 \\
9 & \mathrm{Lj} .\end{array}$ & III & $\begin{array}{l}1 \mathrm{~b} \beta \\
2 \mathrm{c} \gamma \mathrm{K}\end{array}$ & $\begin{array}{l}(\mathrm{gg}) \\
(\mathrm{hg})\end{array}$ & IIV & ${ }_{\mathrm{K}}^{2 \mathrm{c} \beta}$ & $\begin{array}{l}\text { (gg) } \\
\text { (hg) }\end{array}$ \\
\hline$\overline{Z Z}$ & $\begin{array}{ll}4 & \\
9 & \mathrm{Lj} .\end{array}$ & III - II & $\begin{array}{l}2 \mathrm{c} \gamma \\
2 \mathrm{~b} \beta\end{array}$ & $\begin{array}{l}\text { (hg) } \\
\text { (hg) } \\
\end{array}$ & IIII-II & $\begin{array}{l}2 \mathrm{cr} \\
2 \mathrm{bB}\end{array}$ & $\begin{array}{l}\text { (hg) } \\
\text { (hg) }\end{array}$ \\
\hline$\overline{Z Z}$ & $\begin{array}{r}5 \\
10 \mathrm{Lj}\end{array}$ & III & $\begin{array}{l}\text { cydp } \\
\mathrm{dp}\end{array}$ & $\begin{array}{l}\text { (mg) } \\
\text { (hg) }\end{array}$ & III & $\begin{array}{l}c y d p \\
d p\end{array}$ & $\begin{array}{c}(\mathrm{mg}) \\
(\mathrm{hg})\end{array}$ \\
\hline $\mathrm{ZZ}$ & $\begin{array}{r}6 \\
10 \mathrm{Lj} .\end{array}$ & III & $\begin{array}{l}2 \mathrm{cy} \\
2 \mathrm{c \gamma}\end{array}$ & $\begin{array}{l}\text { (gg) } \\
\text { (gg) }\end{array}$ & III & $\begin{array}{l}2 c \gamma \\
2 c \gamma\end{array}$ & $\begin{array}{l}(\mathrm{gg}) \\
(\mathrm{gg})\end{array}$ \\
\hline$\overline{\mathrm{ZZ}}$ & $\begin{array}{r}7 \\
10 \mathrm{Lj} .\end{array}$ & IV & $\mathrm{K}$ & $\begin{array}{l}\text { (hg) } \\
\text { (hg) }\end{array}$ & IV & $\mathrm{K}$ & $\begin{array}{l}\text { (hg) } \\
\text { (hg) }\end{array}$ \\
\hline $\mathrm{ZZ}$ & $\begin{array}{r}8 \\
11 \mathrm{Lj} .\end{array}$ & II & $\begin{array}{l}1 \mathrm{~b} \alpha \\
1 \mathrm{~b} \alpha\end{array}$ & $\begin{array}{r}\text { (gg) } \\
(\mathrm{mg})\end{array}$ & II & $\begin{array}{l}1 \mathrm{~b} x \\
1 \mathrm{bx}\end{array}$ & $\begin{array}{l}\text { (gg) } \\
\text { (gg) }\end{array}$ \\
\hline $\mathrm{zZ}$ & $\begin{array}{r}9 \\
12 \mathrm{Lj} .\end{array}$ & III & $\begin{array}{l}1 \mathrm{~b} \beta \\
2 \mathrm{c} \gamma\end{array}$ & $\begin{array}{r}(\mathrm{gg}) \\
(\mathrm{mg})\end{array}$ & II & $\begin{array}{l}1 \mathrm{~b} \alpha \\
2 c \gamma\end{array}$ & $\begin{array}{l}(\mathrm{gg}) \\
(\mathrm{gg})\end{array}$ \\
\hline $\mathrm{ZZ}$ & $\begin{array}{ll}10 & \\
13 & \text { L. }\end{array}$ & III & $\begin{array}{l}2 \mathrm{c \gamma} \\
1 \mathrm{b \beta}\end{array}$ & (mg) & III & $\begin{array}{l}2 \mathrm{c \gamma} \\
1 \mathrm{~b} \beta\end{array}$ & $\begin{array}{l}\text { (mg) } \\
\text { (hg) }\end{array}$ \\
\hline$Z Z$ & 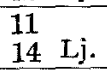 & I & $\begin{array}{l}1 b \alpha \\
1 b \beta\end{array}$ & $\begin{array}{l}\text { (gg) } \\
\text { (gg) }\end{array}$ & I & $\begin{array}{l}1 \mathrm{~b} \alpha \\
1 \mathrm{~b} \beta\end{array}$ & $\begin{array}{l}(\mathrm{gg}) \\
(\mathrm{gg})\end{array}$ \\
\hline$\overline{Z Z}$ & $15 \mathrm{Lj}$. & $I-I I$ & $\begin{array}{l}1 \mathrm{~b} \beta \\
1 \mathrm{aa} \alpha\end{array}$ & $\begin{array}{l}\text { (gg) } \\
\text { (gg) }\end{array}$ & II $-I I$ & $\begin{array}{l}1 \mathrm{~b} \beta \\
1 \mathrm{a} \alpha\end{array}$ & $\begin{array}{l}(\mathrm{gg}) \\
(\mathrm{gg})\end{array}$ \\
\hline $\mathrm{ZZ}$ & $\begin{array}{ll}13 & \\
15 & \mathrm{Lj} .\end{array}$ & II & $\begin{array}{l}1 b \beta \\
2 c \beta\end{array}$ & $\begin{array}{l}(\mathrm{mg}) \\
(\mathrm{mg})\end{array}$ & II & $\begin{array}{l}1 \mathrm{b \beta} \\
2 \mathrm{c \beta}\end{array}$ & $\begin{array}{l}(\mathrm{mg}) \\
(\mathrm{mg})\end{array}$ \\
\hline$Z Z$ & $\begin{array}{l}14 \\
15 \\
\mathrm{Lj} .\end{array}$ & $\begin{array}{l}\text { I } \\
\text { I }\end{array}$ & $\begin{array}{l}1 \mathrm{~b} \beta \\
1 \mathrm{~b} \alpha\end{array}$ & $\begin{array}{l}\text { (gg) } \\
\text { (gg) }\end{array}$ & II & $\begin{array}{l}1 \mathrm{b \beta} \\
2 \mathrm{b \beta}\end{array}$ & $\begin{array}{l}\text { (gg) } \\
\text { (gg) }\end{array}$ \\
\hline$\overline{Z Z}$ & $15 \mathrm{Lj}$. & II & $\begin{array}{c}1 \mathrm{~b} \beta \\
c \gamma \mathrm{K}\end{array}$ & $\begin{array}{c}(\mathrm{gg}) \\
(\mathrm{mg})\end{array}$ & IV & $\begin{array}{l}\mathrm{c} \gamma \mathrm{K} \\
\mathrm{c} \gamma \mathrm{K}\end{array}$ & $\begin{array}{l}\text { (hg) } \\
\text { (mg) }\end{array}$ \\
\hline $\mathrm{ZZ}$ & $\begin{array}{l}16 \\
18 \mathrm{Lj} .\end{array}$ & IIII & $\begin{array}{l}2 \mathrm{c} \gamma \mathrm{K} \\
2 \mathrm{~b} \gamma\end{array}$ & $\begin{array}{l}\text { (hg) } \\
\text { (hg) } \\
\end{array}$ & III & $\begin{array}{l}2 c \gamma \bar{K} \\
2 b \beta \\
\end{array}$ & $\begin{array}{r}(\mathrm{hg}) \\
(\mathrm{mg})\end{array}$ \\
\hline
\end{tabular}

同一個人，左右乳嘴突把，含氡狀態 八例八バ

Turner u. Porter ${ }^{(96)}$ 八 88\%. Talpis u. Liebermann" ${ }^{(90)}$ 八 74\%. Steure1 ${ }^{(87)}$ 八 71.5\%. Beck, J.165 八 70\%. 䉝江八 $73.52 \%=$ 於テ略を一致ス
ト逝べ，其閣二多少ノ變動アルモ。等諸家ノ 成續フ踪合スルニ一致度八 70-80\%ト見テ大 過ナカラン。然ラバ含哉型ノ一致八等質等量, 遗塻物翼 


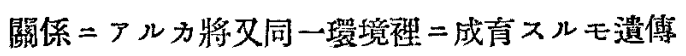
物質，分配 度ヨ取ルモノナルカハ，先ヅ根本的二重娎ナル 問題ナリ。

第 1 表ニヨリテ明カナル如ク，一即兒各組兩兒

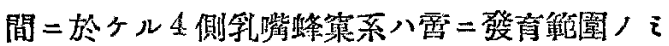
ナラズ．䗋策ノ排列。各蜂案ノ大小，間壁/贆 態. $\mathrm{S}$ 字筫，䐍隆度等アラユル要素ノ酷似スル モノ甚ダ多っ(16例 64\%). 其高度ナルモ（第 1 圆.第 2 圖)二於テハ細心ノ注意习以テスルト モ第 1 兒卜第 2 兒卜／䗋億像フ識別スルコト極 メテ因蜼ナリ。而シラ非相似ヨ示スモく八政か $=9$ 例 (EZ. $1: 4.10 .13 .15 .17 .18 .20 .23)=シ$ テ $36 \%$ 二當ル。然ル二二卵兒二於テハ相似，櫫

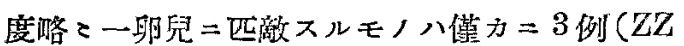
6.7.11) 二過ギズ。然モ此內第 7 例八等シク䋊 密骨性ヨリ成ル含氣乳嘴突起ナルモ．各兒二於

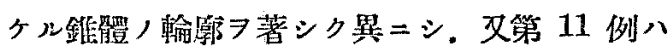

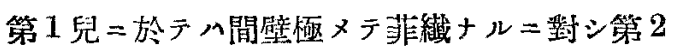
兒ノ夫レ八中等度二肥厚スルノ差異习示セリ。

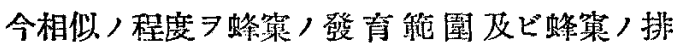
列. 大小. 及ビ間壁／茈態ナル 3 要素中／任意

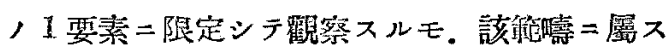
ルモノトシテ面二3例 (ZZ.4.12.13) ラ增ス ノミ。從ツテ相似セルモノ八 16 組中 6 組郎テ

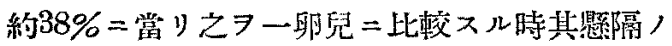
甚ダシキ二警カザルラ得ズ。

次二一即兒二於ヶル非相似組中注意习要スルハ 第 15 例(第 3 圖) 及ビ第 23 例 (第 4 圖) ナ

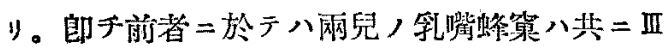

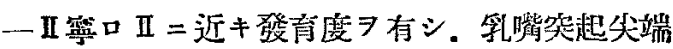
$=1$ 個ノ大ナル終末蜂㽞 $尹$ 形成シ極メテ類似

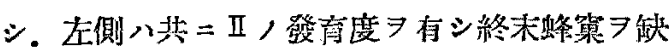

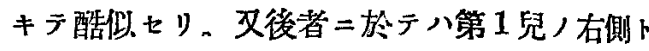
第 2 光ノ左側及ビ第 1 兒ノ左側卜第 2 兒ノ右側 トハ殆ンド完全二一致シ. 所謂鏡像現象フホセ リ。要スル二之等 2 組二於テハ含氣八 4 側乳嘴 突起二均等二分配サレズシテ 夫タ各側每:及ビ 交互側寓二一政セルモノナリ。Tueicher 八斯カ

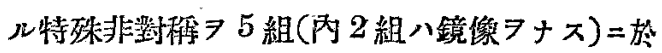
テ篗察セシカ何等注意スル所ナタ. 又 Schwarz 八鏡像現像 ヒシモ依然外的影響フ管ムルモノ、中 =算入七

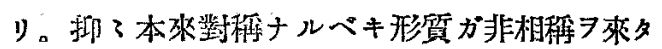
ス本態二關シテ八，辰胎位置異常說。發生異常

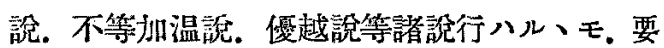
ス $ル$ v. Verschuer $(99)$ ，投ゼル(1)受精セル 畉細胞ノ發有/極初期二於テ遗傅的素因 $ニ ョ ッ$ テ， 決定サル、カ.（2）受精卵發青過程中二 蒙よレル盍傅的甞因及ビ外的影響，和二由來ス ルカ．（3 受精卵發去 $=$ 及ボス純外的影響 $=\exists$ ルカナル 3 命題二統制シ得ン。而シテ現在迄二 於ケル斯方面二關スル研究，結果ニヨレバ非相

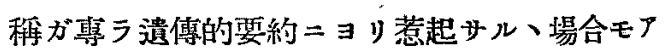
ルコト八疑フ/餘地ナキ所ナリ。熖ツテ以上，

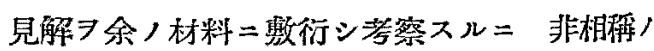
本態自カラ明膫トナルノ霣アリ。蓋シ蜂杲系二 於ケル各側別乃至交互側別相似八極メテ高度= シテ. 後=詳述スル如グ外的影響，所產物卜解 スル能ハザレバナリ。郎チ之等兩例八遺傳物貿 ノ分配異常二由來スルモノナル可ク。一ノ先天゙ 性畸形ト目スルラ得ン。由是筧之，乳嘴蜂菓 遺傅的關係 非對稃 7 外因ナル範瞦二屬セシメ尌ラ 4 側乳嘴 䗋璂二於ケル相似 ト云フ可シ。佁木又 $v$, Eiker ${ }^{(22)}$, Stewrer ${ }^{(89)}$ 等 
八同一個人二於テ左右乳嘴䗋笨像つ著シク相違

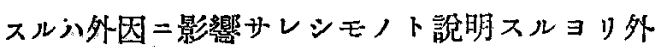
ナシトシテ Wittmaack，訜习支持セルガ. 例 へ非舅稱タナス場合卜雖モ其中二八斯カル先天 性㱦形モ含マル、可能性アルシ以テ 雨氏ノ所 說ハ正當ナリト速斷スルラ哲文ズ。茲二於テ余

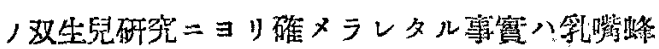

案左右非㻗稃ノ發生本態=關シテモ亦多少，知 見ア扣へタリト云フフ得ンカ。

以上/見解 $コ$ 余八此特異例 7 モ相似踓中一編 大スルラ躊躇セズ。從ツテー卵兒二於ケル相似，

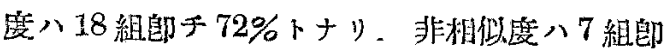
千28\%=減ズ。

第 3 表

\begin{tabular}{|c|c|c|c|c|c|c|}
\hline \multirow{2}{*}{ 朝 告 者 } & \multicolumn{2}{|r|}{ - } & 兒 & \multicolumn{2}{|c|}{$\therefore$} & 兒 \\
\hline & 總組數 & 相 似組 缼 & 非相似組数 & 總組撄 & 租 促組 数 & 非相侧组数 \\
\hline Aibrecht & 22 組 & 16 縕 $=72.7 \%$ & 6 組 $=27.3 \%$ & & & \\
\hline Leicher & 39 組 & 24 組 $=61.4 \%$ & 15 組 $=38.6 \%$ & & & \\
\hline Schwarz & 59 組 & 39 組 $=66.1 \%$ & 20 縕 $=33.9 \%$ & 35 組 & 13 組 $=37.1 \%$ & 22 組 $=62.9 \%$ \\
\hline 崎 & 25 組 & 18 組 $=72 \%$ & 7 縕 $=28 \%$ & 16 組 & 6 縕 $=37.5 \%$ & 10 組 $=62.5 \%$ \\
\hline
\end{tabular}

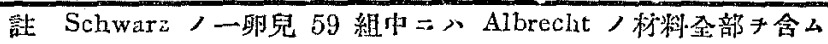

今余ノ成績 7 先進諸家ノ成績ト比䡆センニ。 第 3 表二示ス如ク，一射兒ノ相似度八 Leicher， Schwarz =比シテ谌ダ高キモ, Albrecht トハ 殆ンド全ク一致セり。佾ホ非相似，頻度ガ之卜 遡ノ關係ニアルコト富习侯タズ。次二二卵兒 噛照ト七ルモノ八Sehwarz唯1人アルノそナ ルガ. コハ余ノ成績ト殆ンド全ク一致セリ。

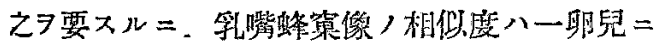
於テ八皆ダ高ク．二卵兒二於テ八約 $1 / 2$ 以下= 減ズ。然力モ二卵兒二於テハ相似，程度一卵睍
ノ域习揧スルモノ八唯 1 例アリシノ 似度八二卵兒ニ於デハ質的二モ量的ニモ著シク 減退スルラ見ル。コハ一般遺傳ノ法則二全ク準 ズルニノニシテ，乳嘴蜂案三於ケル遗傅的要約

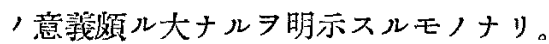

(2) 含氮型的于發育度二關スル相似度。

一卵兒及ビ二卵兒二於ケル乳嘴蜂䆩习余，含 氣型二從ッテ分類シ，各含氣型别二相似度习觀 祭スルニ，第 4 表二示ス如シ。

\section{第 4 表}

\begin{tabular}{|c|c|c|c|c|c|}
\hline \multirow{2}{*}{ 合 } & \multirow{2}{*}{ 氮型 } & \multicolumn{2}{|c|}{ 乳嘴郘起個別数 } & \multicolumn{2}{|c|}{ 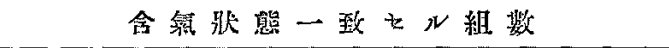 } \\
\hline & & 二卯見 & 三䛇兒 & 兒 & 兒 \\
\hline \multicolumn{2}{|c|}{ 合氮性乳嘴突起 } & $75 \mathrm{Wff}$ & $53 \mathrm{Wff}$ & 13 組 $=52 \mathrm{Wff}=69.3 \%$ & 5 組 $=20 \mathrm{Wff}=37.5 \%$ \\
\hline \multicolumn{2}{|r|}{ I } & $22 \mathrm{Wff}$ & $13 \mathrm{Wff}$ & 5 組 $=20 \mathrm{Wff}=91 \%$ & 2 組 $=8 \quad W f f=61.5 \%$ \\
\hline \multicolumn{2}{|r|}{ II } & $33 \mathrm{Wff}$ & $21 \mathrm{Wff}$ & 6 組 $=24 \mathrm{Wff}=73 \%$ & 2 組 $=8 \quad W f f=38.1 \%$ \\
\hline \multicolumn{2}{|r|}{ III } & $20 \mathrm{Wff}$ & $19 \mathrm{Wff}$ & 2 組 $=8$ Wff $=40 \%$ & 1 組 $=4 \quad \mathrm{Wff}=21 \%$ \\
\hline \multicolumn{2}{|c|}{ 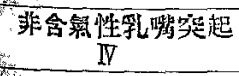 } & $25 \mathrm{Wff}$ & $11 \mathrm{Wff}$ & 5 組 $=20 \mathrm{Wff}=80 \%$ & 1 組 $=4 \quad W f f=36.3 \%$ \\
\hline \multicolumn{2}{|r|}{ 訪 } & $100 \mathrm{Wff}$ & 64 Wef & 18 組 & 6 組 \\
\hline
\end{tabular}

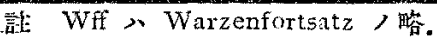




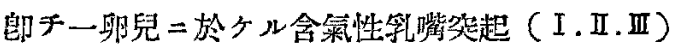
八75 側ニシテ內 52 側 $(69.3 \%)$ 八各組复二一致 シ. 殘伤，非合氣性乳嘴㠾起 (IV) 25 側 $=$ 於テ 八 20 側 (80\%) 八相似シ。前奢二比シ相似度高 キコト約 $10 \%$ ナリ。更二含氣性乳嘴突起 7 余 ，含氣型分類二從ツテ觀察スル $=$ 相似度入第 1 型二於テ最モ高ク第 3 型二於テ最モ低シ。

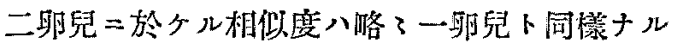

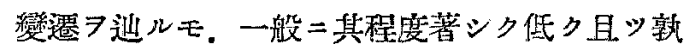
レノ含埭型＝於テモー邲兒二遥カ二及バズ。這 般,關係八第 5 表, 相似曲線二就テ見レバ一目 暸然タり。

第 5 表

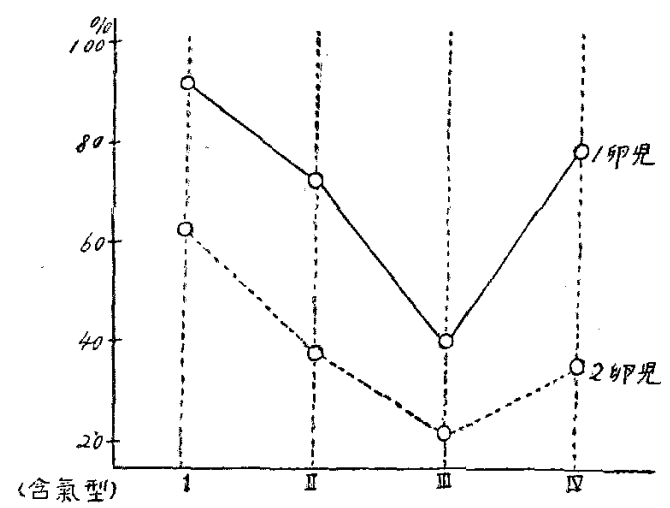

茲二注目ス可キハー卵兒二於テハ第 4 型ノ非含

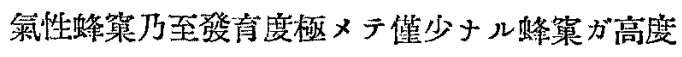
，相似変 $(80 \%)$ フ示シ一見遺僄關係著明ナル コトナリ。然ル＝ Wittmaack ノ主唱スル從爽

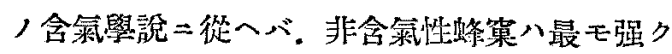
外的影響 (乳兒耳炎) 二障碍サレシ殘貽症ナリ トイフ。果シテ然ラバ各兒，享有スル遗傮物質 八等質等量ナルガ故二，斯ク極メテ酷似スル䗋

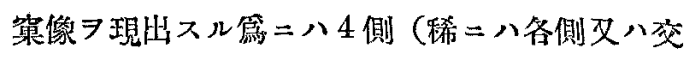
互側) 耳二作用不可キ外因モ亦質. 量及ビ時期 こ於テ相等シカラザル可カラズ。サレド物理乃
至化學的作用ナラバ知ラス。耳资ノ如き病戀が 一再ナラズ. 質量及ビ時期ノ 3 條件 7 等ショシ テ谷異ナル2 個人ノ4 側耳二作用スルト八到底 考へ得ラレザル所ナリ－份隶此見解习豪書スル モノ八同一環境社＝成青七几モ遗傳物質 スル卵兒二於テ八相似，程度一卵兒 $=$ 比又可 キ例㱠ンド皆艌ナリシコトナリ。近時 Witt maack 八說 7 新 $=シ$ 中耳粘膜八各個人二遗傅 サル、モノナル分故二，一畉兒二於テハ外因 $=$ 對スル反應モ亦相等シカルベク．從ツテ例へ4 側乳嘴䗋笨缐酷似セリトモ外的影響フ蒙ムラザ ル純遣傳性ノモノト䀿ズル能ハズト七シ所說ハ 一應光モナルガ如キモ，仔細二吟味セバ此意見 モ亦外因八等質等量ナリト，前提，下二初メテ 承認サル、モノナル以上. 其誤レルコトハ自亏 明カナり。

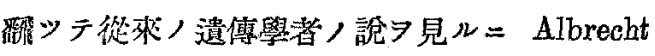
及 Leicher 八共=非含氮性乳嘴突起， 的影響，所噇物卜解シ就中Leicher /如キハ4 側乳嘴突起が等シク非含氣性ナル例 $7 モ$ 非相佂 群中二編大シタル䉆又著シっ高率 (約 $40 \%) ，$

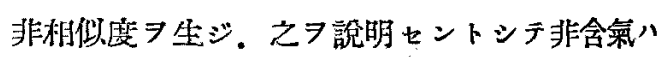
外因，外多ク，人二素質トシテ賦與サル、掫制 因子，作用二因ルモノナラント遮へ：部分的二 八Wittmaack，所說二賛セり，此中二在りテ 獨リ. Schwarz 八純遗傳說 7 昌道七ルガ。余

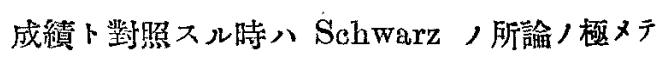

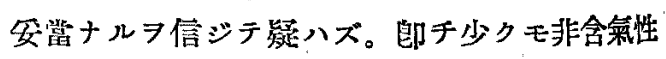
乳嘴突起ノ過牛數八遺傳サル、モノニシテ.コ 八慢性耳炎 $=ョ ル$ 二次的骨象牙質化，續發症† リトセル從來, 見解 7 是正スルニ足ルノミナラ ズ。其發生本態ニ就キテモWittmaackノ云フ ガ如ク含氣機轉初期 $=$ 作用セシ外因 $=\Xi ル ニ$ 非 
ズシテ主トシテ遗㯖的要約ニ基クコトター厦明 膫ナラシムルモノナラン。

倘木第 1 型含氯型師于䗋穼, 發育正常域 7 遙力 二超過スルモノモ．Wittmaack =颃へバ病的蜂

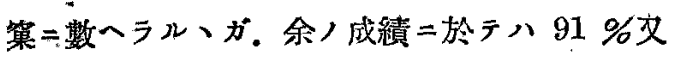
Schwarz ノモノ=於テハ92.2\% 八相似シ．高 度ノ遗傳性フ暗示シ：之二反シ第扛型郎于最近 =於ケルWittmaack，見解ニョレバ蜂策系棈 成二與へル遗傳因子八何等障碍 ク保持サレシ䗋暻群が却ッテ比较的低き相似度 (73\%. Schwarz 74.4\%) 7 嘋七シ八彼我對照 シ頻ル興味媣キ所晃ナリトス。的チ正常以上， 發育シナス蜂笨モ亦遗傳的要約ト緊密ナル關係 ヨ有スル八疑つベクモ非ズ。

\section{（3） $\mathrm{S}$ 宇䁂膨隆度卜含氮狀態卜，關係}

$\mathrm{S}$ 学筫膨隆度卜合氣狀態卜人間二一定ノ相互 關係アルコトハ從來ヨリ知ラレタル所ナり。郎 于含氣不十分ナル程膨隆度强ク。合氣佳良卜土 ルニ從ヒテ嘻隆度フ減ズルラ常トス。而シテ S

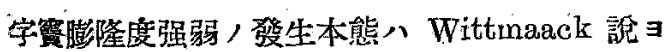

リスレバ虽然含鮄猿碍ノ程度ト逆ノ關係ニアル コトンナリ。換言セバ專ラ外因，程度如何二關 オ。但シ Wittmaack 八此外三遗傅微毒及ビ佝

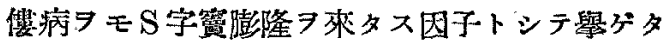
リ。余八其真第 7 再檢討ょントス。

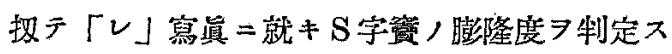

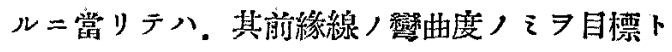

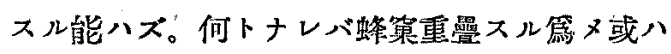
頭位，變動ニヨリ $\mathrm{S}$ 字簤瑇，影像八種々ナ儿差

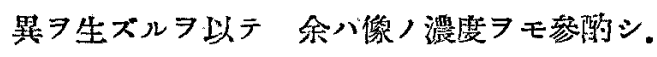
軗底(gg. 影像不明睹ナルモノ). 中等度 (mg. 影 像明膫ナルモノ). 高度(hg. 極メテ明瞭ナルモ ），3階梯二分チテ觀繁セリ。但シ一般= S

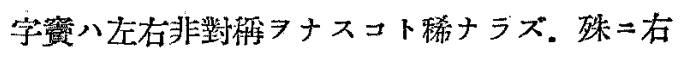
側 =於テ强大ナルコト往々ナルガ故=，成續，

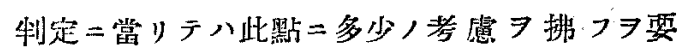
z。

余）成潁 7 概括スレバ第 6 表 如シ（少木第 1 表及ビ第 2 表參照)。

第 6 表

\begin{tabular}{|c|c|c|c|c|c|c|c|c|c|c|}
\hline \multirow{2}{*}{$\begin{array}{l}\text { S 字富！ } \\
\text { 璐隆度 }\end{array}$} & \multicolumn{2}{|c|}{ 各側㓢所見 } & \multicolumn{2}{|c|}{ 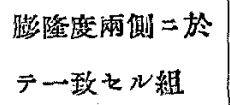 } & \multicolumn{2}{|c|}{ 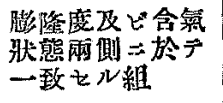 } & \multicolumn{2}{|c|}{ 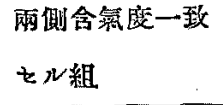 } & \multicolumn{2}{|c|}{ 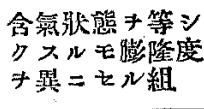 } \\
\hline & $\mathrm{EZ}$ & $Z Z$ & $\mathrm{EZ}$ & $Z Z$ & $\mathrm{EZ}$ & $Z Z$ & $\mathrm{E} Z$ & $z Z$ & $Z$ & $2 Z$ \\
\hline 輕 & 46 側 & 30 側。 & $\stackrel{9}{=} 36$ 租 & $\stackrel{3}{=} 12$ 組 & 8 組 & 3 組 & 9 組 & 3 組 & & \\
\hline 中 等 度 & 25 侧 & 19 㑡 & $\stackrel{4}{=} 16$ 組 & $\stackrel{1}{=} 4$ 組 & 4 組 & 1 組 & 4 組 & 1 組 & 1 組 & 2 組 \\
\hline 高 & 29 側 & 15 側 & $\stackrel{5}{=} 20$ 組 & $\stackrel{2}{=} 8$ 組 & 5 組 & 2 組 & $5 \quad$ 組 & 2 組 & & \\
\hline 計 & 100 側 & 64 ，側 & 18 組 & 6 組 & $\begin{array}{l}17 \text { 維 } \\
=68 \%\end{array}$ & $\begin{array}{cc}6 & \text { 組 } \\
38 & \% \\
\end{array}$ & & & & \\
\hline
\end{tabular}

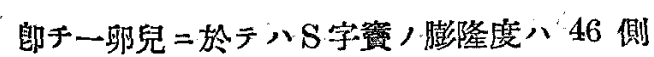
整度. 25側中等度. 29側高度ニシテ.二卵兒二於 テ八 30 側. 15 側. 19 側 /順二同樣 /階梯 7 占 4。而シテ此內膨隆店が 4 側耳二於テ同一關係
ンアルハ一卵兒 18 組。耶兒 6 組ニシテ更二含

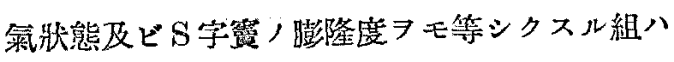
(第 5.6 四參照) 一卵兒二於テ 1 組 i。郎チ一卵兒 17 組 $(68 \%)$.二卵兒 6 組 $(38 \%)$ 
ンシテ 二卵兒二於ケル相似度八著シク低シ。 倘ホ此通則二反スルモノ换言七バ含氣狀態 7 等 シクスルモ膨隆底 $=$ 於テ 1 組. 異留双生兒二於テ 2 組 7 算スル， $i$ 。次二膨隆度並二含氣狀態 7 等シクスル1碓

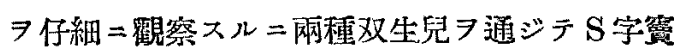

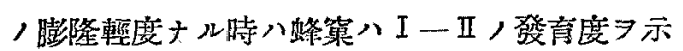
シ、膨隆中等度ナルモノハII一吕，含氣型二屬

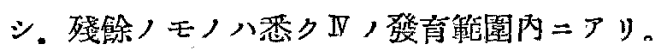

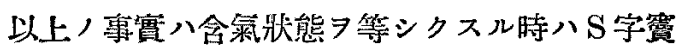
八膨隆度モ等シク。且ツ䗋宣ノ發育度习減ズル

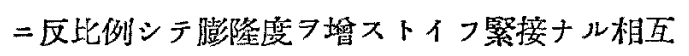
關係アルラ示スモノナリ。而シテ此際二於ケル 相似率が同翼双生兒二於テ甚ダ高ク－一方含氣 咷態が遗傳的要約ニヨリ支配サル、コト二想到 セバ Wittmaack = 反シ $\mathrm{S}$ 字賞, 膨隆度モ亦遗 侸性ナル可キ八察スルニ難カラズ。但シ余ノ材 料二於テ八遺傅微毒或八佝僂病患者昰無ナリシ

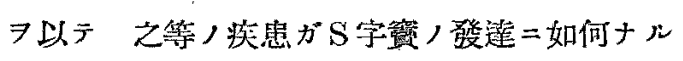
影響ア及ボスモノナリヤ八批制/限リ二非ズ。

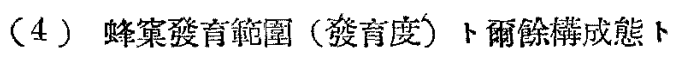
關係

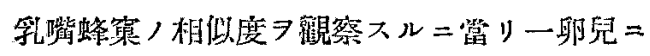
於テ八蜂窠, 發育度 7 等シクスル時八例外ナク

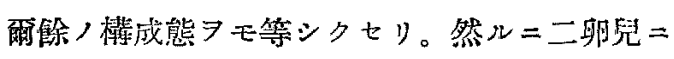

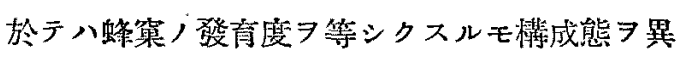

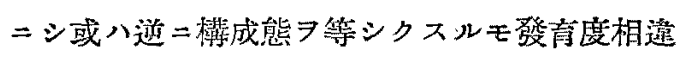
スルコト多ク．完全ナル一致ト目ス可キ八唯 1 例二過ギズ。例へベ二卵兒，第 13 例（第 7 圖） ハ2 兒共䗋案, 發育極メテ良好ナルガ第 1 兒， 䗋案系ハ中細胞性ニシテ規則正ショ。第 2 兒八 排列極メテ不規則ナリ、又二卵兒）第 8 例（第 8 圖) ハ4 側蛒策八孰レモ中細胞性ニシテ，間
壁菲薄. 排列規則正シキモ. 第 1 兒ノ發育度八 Iナルニ反シ第 2 兒ニ於テハI，發有度习示七 リ。

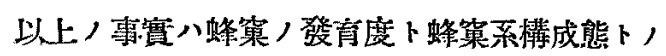
間二八密接ナル關係アルラ示スモノニシテ. 然 カモ之ガ名ンド尃ラ等質双生兒 =於テ：見ラ レシハ遗侸的要約二基クコトヨ暗示ス。サレバ 本事算八Wittmaack ガ合氣狀態ノ種タ相习質. 量及ビ時期ナル 3 要素ノ種々ナル組合セノ下 作用七シ外因ノ殘唄拝ナりト七ル說习以テシテ 八到底訩明スル能ハザル所ニシテ，遗傳說 $=ョ$ ツテノで初メテ首肯シ得ル解答ヨ與フモノナ リ。倚示本事實八蜂稚系フ支配ス几多數ノ遺傳 因子中其發青笘圍 7 規定スル因子八就中最モ重 要ナル意挛ア有スルコトフ推測セシム。

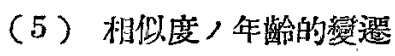

一卵兒卜二卵兒 75 歲ヨy 10 歲。11歳 15 歲及ビ夫レ以上/ 3 階梯二分チテ相似度 7 䅐 察スル二. 第 7 表二示スガ如ク，一卵兒二於广

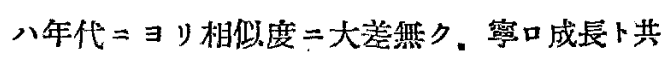
二增加スル傾问オ示スガ 之二反シ二卵兒二於 テ八相似度い年潘 向著明ナリ。從來カ、ル關㛊二著目七ル研究焎 ク. 又余，篗察材料モ亦十分ナラザルガ故 $=$. 決定的ノコトハ云ヒ得ザルモ。. 少クトモ乳㗪峰 窠ノ成形二與儿遗傅因子ハー卵兒二於テ八年龄 ニョッテ等質等量，均衡失ハル、コト少ク.二 卵兒ニ於テハ遗倠物翼，美異八次第二著明トナ

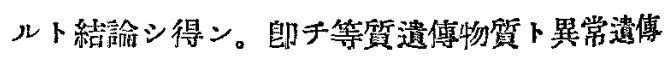
物質トハ夫 、乳㗪䗋巢系二甚大ナル影響习及ボ

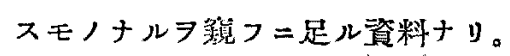




\begin{tabular}{|c|c|c|c|c|c|c|c|c|}
\hline \multirow{2}{*}{\multicolumn{2}{|c|}{ 年 代 別 }} & & - & 切 & 兒 & \multicolumn{2}{|c|}{$=$ 卵 } & 兒 \\
\hline & & \multicolumn{2}{|c|}{ 總 組 数 } & \multicolumn{2}{|c|}{ 租似々N組数 } & \multicolumn{2}{|c|}{ 總 組 孜 } & 相似セル組缕 \\
\hline & -10 歳 & 6 & 組 & & 組 $=66 \%$ & 7 & 維 & 3 組 $=43 \%$ \\
\hline & $1-15$ 緘 & 11 & 組 & & 組 $=73 \%$ & 5 & 組 & 2 組 $=40 \%$ \\
\hline & 3 濒 以上 & 8 & 組 & & 組 $=75 \%$ & 4 & 組 & 1 組=25\% \\
\hline
\end{tabular}

\section{（6）外因，程度}

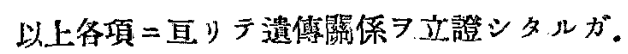

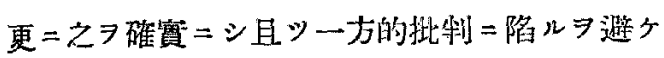
ンガ篇メ. 外因ニッキ考究セン。

双生兒病理八原则ヨリシテ形質ノ非相似八外因 ノ影響卜解サル、モノニシテ，余，成緽二於 テハ既述ノ如ク（第 3 表）28\%フ算ス。此僓八 Albrecht 及 Schwarz = 略?一政シ. Leicher 二此シ遥カ二僅少ナルモ. Leicher ト八相似， 制定ニシキ見解ノ相違アルョリ見レバ䨋然ナル

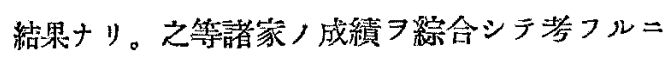
外因ノ程度八比較的僅少ナリト云七得可ク若シ

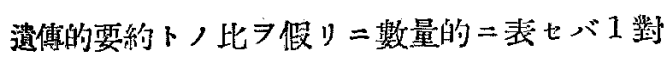
3 /船合トナル。をョリシテモ. Wittmaack

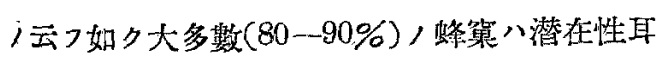
炎ナル外的影響习蒙んレリトスル所諭二八句諭 餋成スル能ハズ。，ミナラズ茲二舆味アルハー 卵兒，第 14 例(第 9 圖)广り。郎于第 1 兒八生後 3 ケ月ニシテ右側中耳化膘应二䍜り。第 2 兒八 第1兒ョリモ約 1 ケ月遲レテ反對側的チ左側，

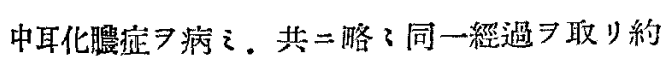
1タ月ニシテ全治セルモノナリ。14年後二行ヒ

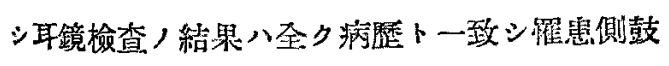
膜八輕度二浭濁シ。略こ中央二小ナル躬痕アリ。

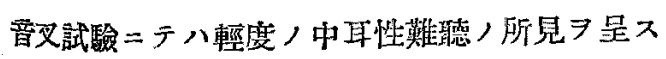
ルモ。聑語ハ $6 \mathrm{~m}$ 德取シ得。而シテ之等网兒

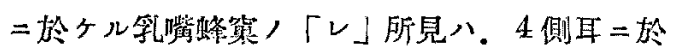

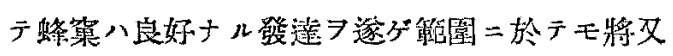

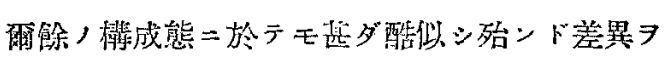
見出スコト能ハザリキ。コハKnick $u$. Witto (36)，所見二符合スルモノナルガ。民等ノ研究が 單二同一個人ノ健側耳７對照卜七ル二反シ. 余

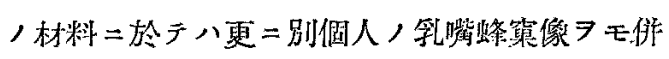
七批制シタル結果ナルガ故二、氏等/見解二對 シ一愿有力ナル證明 7 與へタルモノナリ－如斯 例一急性耳炎二侵サル、トモ䗋案系八常二影響 フ蒙ムリ全貌习變ズルトハ限ラズ。郎千此際各 個人 =頲傅》レタル中耳粘膜, 抵抗力如何が重 要ナル役割 ッテ臨牀症狀 全ク䬢クガ如キ極メテ輕症ナル 潜在性耳炎二作用サレ大多教，蜂害が變化スル ト八蒌ジテ考人得ザル所ニシテ、余ハAlbrecht 卜共二本耳炎

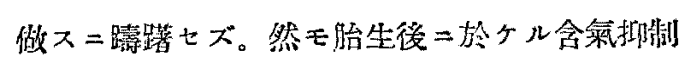

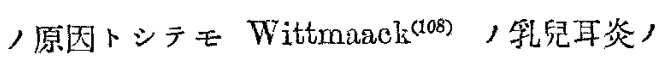
外 $=$ Schuelle ${ }^{(64)} \sim$ Dysostosis cleidocranialis 及ビ Marmorknochenkrankheit 7 .Van Gilse (25) 八何傁病及ビ Mongolische Idiotie $\Rightarrow$ Alb-

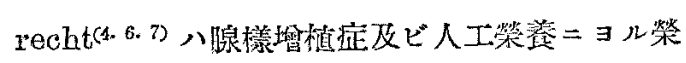
養陪碍 7 㦛乡゙ 久含氣促進因子トシテ Schueller $\mathrm{r}^{(64)}$ 八肢端肥大症 7 .Proskurjakon ${ }^{(16)}, \mathrm{Ya}$

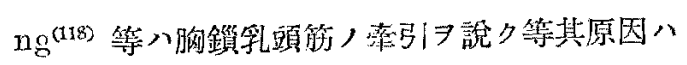

$$
11 \rightarrow 99
$$


單一ナラズ。サレバ獨り乳兒耳炎ノミガ後年， 乳嘴䗋菓像 aack , 所說ニハ大ナル價值 7 犆キ難シ。

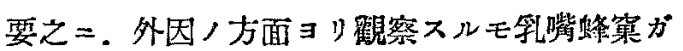
主トシテ遗傳的要約ニヨリ規定サル、モノナル

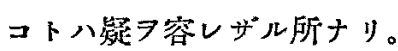

\section{第三箁 結 論}

1. 岡山縣及ビ其路接諸縣在传/双生兒中ヨリ 蒐集シ得タル同性双生兒 41 組 ( 5 歳ヨリ23歲

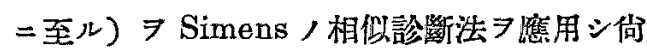
木耳鼻咽喉科的見地 $コ$ リ相似形犋 7 取捨選擇 シタル上. 一卵兒八 25 組. 二沺兒ハ 16 組ナ ルコトラ確メタリ。

2. 斯クシテ鑑别シタルー卵兒 25 組ニ於ケル

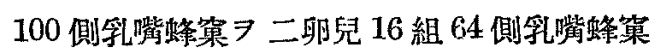

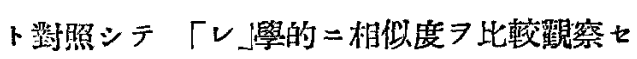
$n=$ 。次ノ如キ結果 7 得夕リ。

(1) 概括的相似度八一卵兒72\%.二卵兒37.5

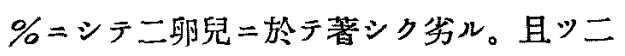
卵兒二於于八貿的二モ相似，程度一卵兒 $=$ 匹敵スルハ僅カ $=1$ 例フ算シタルノえ。

(2) 同質双生兒 $=$ 於テ乳嘴䗋巢系が夫?各 側旬:及ビ交互側每: 二一致シ。然王其相似度 極メテ高度ナルノぇナラズ. 現在，遺傳說 ヨリシテ之ガ外因，影響卜解スル能ハザル モノ2 組ヲ観察七リ。此事實ヨリシテ同一 個人, 左右䗋笨像著シク相違スル八外的影 響ナリトセシ從東，見解ハ直チニ承認スル
F得长。

（3）從來ノ含氣學說ニヨレバ最キ甚大ナル 外的影蠁フ蒙ムリタリト看做サレシ非含氣

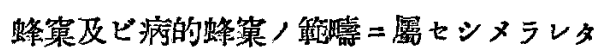
ル發育度正常以上ノ䗋架ガ著シク高率ノ相 似度 $(80 \% .90 \%) \exists$ 示七り。

（4） S 字簤，膨隆度八含氣狀態卜密接ナル 關係アリ。郎チ膨隆著明トナル二反比例シ テ蜂巢, 發肖度フ減ズ。而シテ兩條件二關 スル相似度八一那兒 68\%.二卯兒 $38 \%=$ シテ。二卵兒二於テ著シク劣ル。

(5) 一邲兒二於テ八䗋巢ノ發育度习等シク

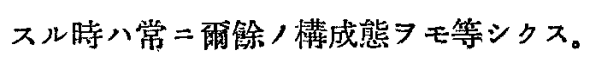
コハ二卵兒二適合セズシテ，分配サレシ遺 傳物質，等質ナルカ異質ナルカ二因ルモ， ナラン。

（6）一即兒二於テハ年龄 $=ヨ$ リ相似度=變 動习來タ又事僅少ナルモ。二卵兒二於テハ 年䉁ラ增スニ從ッテ次第二相似度习減ス。

（7）外因ノ程度八僅少ニシテ. 若シ數量的 =裴セバ $28 \%=$ 當ル。又含氮機轉初期二 急性中耳炎 7 經過七ル場合二於テモ䗋窠系 ノ全貌常ニ著シク變化スルトハ隄ラズ。

3. 叙上/事實 $コ$ シテ余八 Wittmaack ガ後 年者 $=$ 於分儿乳嘴䗋策像八大多數乳兒耳炎= ヨリ影響サレシ殘䀫像ナリトスル說フ承認ス ル能ハズシテAlbrecht及ビSchwarz，遗 稘說二賛成スルモノナリ。

擱等スル 
文

1) Albrecht: Pneumatisation u. Konstitution. Z.f.H.N.O. Bd. 10, S. 51, 1925. 2) Dexselbe: Mittelohreiterung u. P. des Wff. Z.f.H.N.O. Bd. 10, S. 55, 1925. 3) Derselbe: Die Bedeutung d. Konst. bei den Erkrankungen des Ohres u. der Luftwege. Z. f. Laryng. Bd. 14, S. 1, 1926. 4) Derselbe: Die Bedeutung d. Erbmasse bei Infektionen d. Schleimhäute $u$. die Methoden ihrer Forschung. Acta oto-laryng. Vol. 11, P. 16, 1927. 5) Derselse: Zur Frage d. P. des Mittelohres. Acta oto-laryng. Vol. 14, P. 221, 1930. 6) Derselbe: Uber Konstitutionsprobleme in der Pathogenese d. Hals-, Nasen-, u. Ohrenkrankheiten. Z.f.H.N.O. Bd. 29, 1931. 7) Derselbe: Die allg. Konst. u. ihre lokale Auswirkung in Hals-, Nasen- u. Ohrenkrankheiten. 8) Albrecht u. Schwarz: Anlage u. P. A.f.O. Bd. 134, S. 50, 1983. 9) Albrecht: Die erblichen Ohrenleiden u. das Gesetz zur Verhütung des erkranken Nachwuchses. Z.f.H.N.O. Bd. 36, S. 262, 1934. 10) Altmann u. Vexmes: Über einige prinzipiell wichtige histologische Befunde an Menschenaffenschläfenbeinen. M.f.O. Jg. 67, S. 862, 1933. 11) Ambers: Wittmaaeks views concerning the normal and pathologic $P$. of the temporal bone. Zbl. f.H.N.O. Bd. 3, S. 497, 1923. 12) Aschof: Die Otitis media neonatatorum. Z.f.O. Bd. 31, 1897. 13) Baner u. Stein: Konstitutionspathologie in der Ohrenheilkunde. J. Springer. 1926. 14) Bauer: Vorlesungen uiber allg. Konstitutions) u. Vererbungslehre. J. Springer. 1923. 15) Beck, J.: Pathologischanatomische Untersuchungen über die Mastoiditis, zugleich ein Seitrag zur Frage usw. Passows Beiträge. Bd. 24, S. 12, 1926. 16) Beek, J.: Beziehungen d. P. d. Wff. der Nasennebenhölen. Z.f.H.N.O. Bd. 18, S. 672, 1927, 17) Bezold: Corrosionsanatomie des Ohres. München. 1882. 18) Brodk: Trommelfelbild a. P. des Wff. Z.f.H.N.O. Bd. 15, S. 241, 1926. 19) Carmody: The development of the sinuses and the influence

\section{献}

of infection upon their development. Transact. of the Acad. of Ophth. and Oto-laryng. P. 383, 1925. 20) Curtias: Nachgeburtsbefunde bei Zwillingen u. Ähnlichkeitsdiagnose. Arch. f. Gynaek. Bd. 140, S. 361, 1980. 21) Deeking: Epelidenuntersuchungen zum Ausbau der Siemensschen Methode zur Diagnose der Eineiigkeit. :M.M.W. Jg. 73, S. 1188, 1926. 22) v. Eiren: Diskussionsbemerkung auf d. 1 . internat. Oto-Rhino-Laryng. Kongress in Kopenhagen. 1928. Zbl. f. O. Bd. 30, S. 149,1929 . 23) Eisinger: Untersuchungen über die P. des Schläfenbeis. 1. intern. Kongress zu Kopenhagen. 1928. Zit. nach Zbl. f. H.N.O. Bd. 8, S. 38, 1929. 24) Van Gilse: Uber die Entwicklung. d. Keilbeinhöhle des Menschen. Z.f.H.N.O Bd. 16, S. 202, 1926. 25) Derselbe: Diskussionsbemerkung auf d. 1. intern. Kongress in Kopenhagen. 1928. Zbl. f.O. Bd. 30 , S. 149,1929 . 26) Görke: Die exsudativen u. plastischen Veränderungen im Mitterohr. A.f.O. Bd. 65, S. 226, 1905. 27) Derselbe: Diskussionsbemerk. auf d. I. intern. Kongress in Kopenhagen. 1928. Zbl. f. O. Bd. 30, 1929. 28) Grahe: Hai d. Muskelzug am Sternocleidomastoideus einen Einfuss auf die P. des Processus mastoideus? Z.E.H.N.O. Bd. 20, S. 278, 1928. 29) Hanse: Akute M.O. Entz. u. P. des Wff. Z.f.E.N.O. Bd. 25, S. 424, 1930. 30)

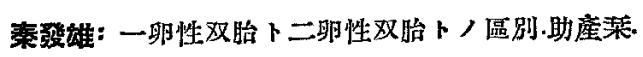
第368號，2273真，大. 15 . 31) Feimemamn: Die Röntgenaufnahme des Wff. u. ihre klinische Bedeutung. Passows' Beiträge. Bd. 19, S. 41, 1923. 32) Hesse: Beiträge zur Bakteriologie u. Klinilk akuter Mitterohreiterung, usw. Z.f.H.N.O. Bd. 22, S. 372, 1929. 33) Dexselke: Blutgruppenzugehörigkeit u. P. des Wff. Z. f. Laryng. Bd. 17, S. 240, 1929. 34) Komai and Fukuoka: A set of dichorionic identical triplets. Jour. of Heredity. Vol. 22, P. 233, 1931. 35) 古屋芳婎: 䨤生學原理卜人類遗傳學. 昭6. 36) Kuick a. Witte: Röntgenologische Studien 
über die Entwicklung d. Warzenfortsatzzellen nach Otitis media im ersten Leben Sjahr. A.f.O. Bd. 119, S. 128, 1928. 37) Kretselnmann: Diskussionsbemerk, zum Vortrag von Wagener. Verhandl. d. Ges. dtsch. Hals-, Nasen- u. Ohrenärzte. 1921. 38) Krainz: Entstehung us Verlauf d. Mastoiditis. Z.f.H.N.O. Bd. S. 488 , 1925. 39) Kriegsmann: Röntgenologische Untersuchungen an Wff. nach durchgemachter Otitis. Z.f.H.N.O. Bd. 29, S. 259, 1931. 40) 國

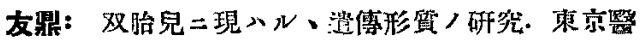
誌, 2799號, 47.頁, 昭7. 41) Lange, s.: Röentgenray examination of the mastoid region. Ameri, Roentgenray Soc. Vol. 9, 1909. 42) range, W.: Jie pathologische Anatomie d. Mastoiditıs. Z.f. H.N.O. Bd. 20, S. 1, 1928. 43) Derselbe: Tiefgelegene Entzuendungsherde in Schläfenbein. Z.f.II.N.O. Bd. 32, S. 99, 1933. 44) Leicher: Die Vererbung anatomischer Variationen d. Nase, ihrer Nebenhöhlen u. des Gehörorgans. München. 1928. 45) cenz: Zur Frage d. Erblichkeit d. Muttermäler. M.M.W. S. 1365, 1924. 46) Ï̈beu: Ohroperation im frühen Kindesalter $u$. Pneumatisationsentwicklung. Z. f. Laryng. Bd. 21, S. 326, 1931. 47) Maxtin: Lehrbuch d. Antropologie. Jena. 2. Auf. 1928. 48) Marx: Zur Frage d. Bedeutung d. M.O. Entz. des frïhesten Kindesalters für später. A.f.O. Bd. 126, S. 71, 1930. 49) Meirowsky: Zwillingspathologie u. Äthiologie d. Muttermäler. Dermatol. Wochenschr. Bd. 79, S. 973, 1924. 50) Mrayer, E. G.: Otologische Röntgendiagnostik. J. Springer. 1930. 51) Meyer, M.: Pathologisch-anatomische Untersuchungen zur Frage d. akuten Otitis $u$. d. Indikation zur Antrotomie. Passows' Beiträge. Bd. 26, S. 233, 1923. 52) Merselbe: Über Konst. u. Mitterohrschleimhaut. Z.f.H.N.O. Bd. 29, S. 106, 1981. 53) Meyer, W.: Ergebnisse röntgenologischklinischer Untersuchungen zur Frage d. sekundären Sklerosierung des Wff. A.f.O. Bd. 130. S. 292，1932. 54）見波定治：遗售學. 第2版，昭3. 55) Mittermaier: Die Krankheiten. d. Nasen- nebenhühlen u. des Ohres im Röntgenbild. 1934. 56) Mouret: Annales des maladies de l'oreille etc. 2. 1913. Zit nach Wittmaack; Uber die nor male u. pathologische P." .57) Mygind: Diskussiosbemerk. auf d. 1. intern. Kongress in

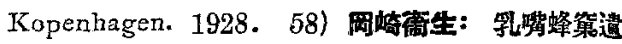
傳二就デ/研究·大日耳鼻.40管, 1842頁, 昭9，59)

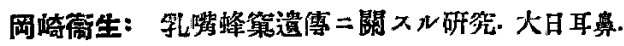
41告, 1407頁, 昭10. 60) Politzer: LehIubuch d. Ohrenheilkunde. Stuttgart. 1901. 61) Prosknurjakow: Úber die Wịkung des einseitig gesteigerten Muskelzuges des Sternocleidomastoideus auf den Wff. bei Torcicollis. M.f.O. Jg. 68, S. 808, 1934. 62) Rietschel: Die klinische Bedeutung d. Otitis media des Sänglingsalters, insbesondere usw. Therapeut. Monatshefte. Bd. 23, S. 313, 1909. 63) Richter: Uber familiäres Auftreten d. entzuendliçhen Mittelohrerkrankungen. Z. f. Laryng. Bd. 21, S. 319 , 1931. 64) Schüuler: Diskussionsbemerk. auf d. I. intrn. Kongress in Kopenhagen. 1928. 65) Rollin: Beiträge zur Kenntnis der Mucosusm Otitis. A.f.O. Rd. 137, S. 338, 1924. 66) Range: Über Indikationsstellung zur Mastoidoperation auf Grund d. Röntgenbildes. Z.f.O. Bd. 81, S. 351，1921．67）下田伯一：瀬顬骨/組織解剖學 的研究. 大日耳胃. 38卷, 1頁, 昭7.68) Schüler: Uber Röntgenuntersuchungen bei Krankheiten des Schädels u. Gehirns. Wien. med. W. Jg. 58, S. 501, 1908. 69) Sehwara: Die Bedeutung d. hereditären Anlage für d. P. der WH. u. Nasennebehöhlen. A.f.O. Bd. 123, S. 1929. 70) Derselbe: Das individülle Verhalten d. Schleimhat propria im Mittelohr $u$. ihrer Entwicklung u. ihres Gewebsaufbau. Z.f.H.N.O. Bd. 29, S. 98, 1931. 71) Derselbe: Untersuchungen zur individüllen Histologie des Bindegewebes. A.f.O. Bd. 129, S. 1, 1931. 72) Schwarze u. Eysel: Über die künstliche Eröffnung des Wff. A.f.O. Bd. 7, S. 157,1873 . 73) Shea: The persistent infantile ethmoid. Ann. of Otol. Vol. 33, P. 1256,1924 . 74) Shea: The normal 
and pathological development of the sinuses. Zbl. f.H.N.O. Bd. 10, S. 508, 1927. 75) siemens: Einfürung in d. allg. u. spez. Vererbungspathologie des Menschen. Berlin. 2. Auf. 1923. 76) Derselbe: $Z$ willingspathologie. J. Springer. 1924. 77) Derselbe: Zur Äthiologie Turmschädels, nebst Mitteilung einer dermatologischen Methode zur Diagnosè d. Eineiigkeit bei $Z$ willingen. Virchows' Archiv. Bd. 253, S. 746, 1924. 78) Derselbe: Die Diagnose d. Eineiigkeit geburtshilficher u. in dermatologischer Beobachtung. A.f. Gynäk. Bd. 126, 1925. 79) Derselbe: Über die Eineiigkeitsdiagnose d. Zwillinge aus den Eihäuten u. aus den dermatologischen Befunde. 80) Derselbe: Vererbungs- u. Konstitutionspathologie d. Ohres a. d. oberen Luftwege. Z.f.H.N.O. Bd. 29, S. 3, 1931. 81) Derselbe: Die Vererbungspathologie d. Mundhöhle. M.M.W. Jg. 41, S. 1747, 1928. 82) Singex: Ưber entzündliche Erkrankungen des Mittelohres usw. Z.f.H.N.O. Bd. 32, S. 110, 1933.

83). Sommer: Familienforschung u. Vererbungslehre. Leipzig. 1922. 84) Sonnenkalb: Darstellung d. pneumatischen Systems am Lebenden. Verhandl. dtsch. otol. Ges. Bd. 22, S. 367, 1913. 85) Derselbe: Röntgendiagnostik. DenkerKahlers' Handb. Bd. 6, S. 1048, 1926. 86) Stenvers: Röntgenologie des Felsenbeines u. des bestemporalen Schädelbildes. J. Springer. 1928. 87) stcurer: Die Röntgenbild d. Wff. u. seine klinische Bewertung. Z.f.H.N.O. Bd. 12, S. 504, 1925. 88) Derselbe: Anatomische Studien uber den Aufbau d. Mittelohr-Schleimhaut usw. Z.f.H.N.O. Bd. 15, S. 261, 1926. 89) Derselbe: Zur Frage d. P. des Wff. Z.f.H.N.O. Bd. 29, S. 113, 1931. 90) Talpis u. Liebermann: Über Pneumatisierung des Wff. ZbI. f. H.N.O. Bd. 11，S. 848，1928. 91）田中文男: 大

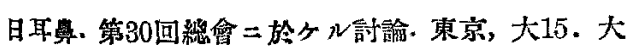
日耳悬. 32怣，296頁，大15。92) 谷口虎年：双胎 ，砛究. 昭10. 93) Ter-Organesjan: Entwicklung d. Nebenhöhlen d. Nase während d. intrauterinen Lebens. Zbl. f.H.N.O. Bd. 12, S. 34，1928. 94) 寺尾新：優生學卜生物湘定學. 炤 7. 95) Theissing: Röntgenologische Untersuchungen über die Struktur des Wff. Z.f.H.N.O. Bd. 25, S. 137, 1930. 96) Tnrner u. Porter: The structural type of the mastoid process, based upon the sciographic examination usw. J. of Laryng. Otol. Vol. 37, P. 115, 1922. 97) Undritz: Über die Bedeutung d. Erbfaktoren beí verschiedenen oto-rhino-laryng. Erkrankungen. A.f.O. Bd. 119, S. 270, 1928. 98) Voss: Diskussionsbemerk. auf d. 5. Tagung suedwestdeutscher IHals-, Nasen- u. Ohrenärzte in Tübingen. 1925. 99) v. Versehmer: Der gegenwärtige Stand d. Zwillingsforschung. Arch. f. soz. hyg. u. Demogr. N.F. Bd. 1, S. 140, 1925. 100) Derselbe: Antropologische Siudien an ein-u. zweieiigen $Z$ willingen. $Z$. f. indukt. Abstammungs- u. Vererbungslehre. Bd. 4l, S. 115, 1926. 101) Derselbe: Grundlegende Frage d. vererbungsbiologischen Zwillingsforschung. M.M.W. Jg. 78 , S. $1562,1926$. 102) Vesalias: $\mathrm{Zit}$ nach Galen : "A brief history of the early development of the anatomy of the ear." Laryngoscope. Vol. 54, 1934. 103) wagener: Zur Frage der P. des Wff. I. Verhandl. d. Ges. dtsch. Hals-, Nasen- a. Ohrenärzte in Nuerunberg. 11921. 104) Weidenreich: Über formbestimmende Ursachen an Skelet u. die Erblichkeit d. Knochenform. Arch. f. Entwicklungsmech. d. Organismen. Bd. 51, S. 436, 1922. 105) Weita: Studien an einefigen Zwillingen. $Z$. $f$. Iklin. Med. Bd. 101, S. 115, 1924. 106) Wildermuth: Die lufthaltigennebenräume des Mittelohres beim Menschen. Z. f. Anat. u. Entwickl. Bd. 2, S. 22, 1877. 107) Wittmaack: Trommelfellbild a. Pneumatisationszustand. Passows' Beiträge. Bd. 9, S. 115, 1917. 108) Derselbe: Uber die normale u. die pathologische P. des Schläfenbeins. Jena. 1918. 109) Derselbe: Der Einfluss d. Anatomie des Mittelohres auf den Verlauf d. Mittelohrentzündungen. t. intern. 
otorhino-laryng. Kongress in Kopenhagen. 1928. 110) Derselbe: Cholesteatombildung, P. u. Pneumatisationslehre. A.f.O. Bd. 125, S. 218, 1930. 111) Derselbe: Zür Frage d. Bedeutung d. $M$, O. Ent. des frühesten A.f.O. Bd. 129, S. 207 , 1981. 112) Derselbe: Schleimhautkonst. u. P. A.f.O. Bd. 132, S. 261, 1932. 113) Derselbe: Wie entsteht ein genuines Cholesteatom? A.f.O. Bd. 137, S. 306, 1933. 114) Yamashita, K.:
Über die Schläfenbeinzellen. 耳鼻棵䠦. 27聕,

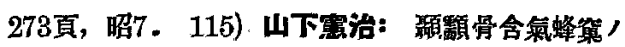
擈成態亚二合氮型二就テ.大日耳鼻. 41 卷, 1002頁,

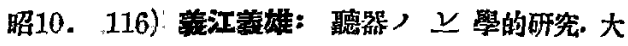

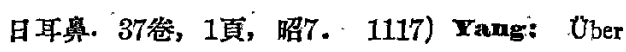
den Eintluss des Muskelzugs auf Entstehung u. Wachstum des Wff. Z.f.H.N.O. Bd. 22, S. 272, 1928. 118) Znekerkandl: Zür Anatomie des Wff. M.f.O. Jg. 13 , S. $49,1879$.

\section{附圖說明}

第 1 圖 EZ。筑 21 例令令 16 啙。

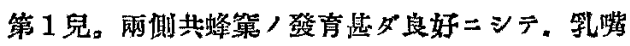

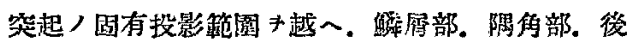
$\mathrm{S}$ 字繁部ニ及ブ。蜂策入中細胞性ニシテ，間壁菲

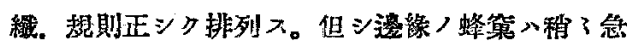

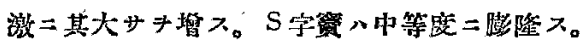

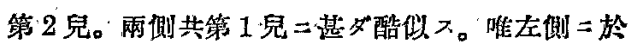

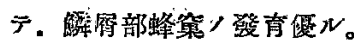

第 2 圖 $\mathrm{EZ}$ ，第22例令令 17盛。

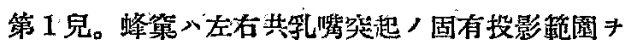

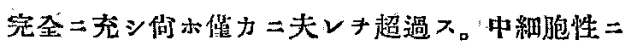

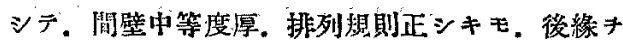

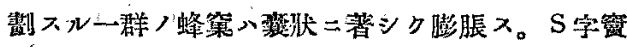
八秒、前方二作移入。

第 2 兒。雨倪蜂笨系ハ第 1 兒二極メテ酷似ス。唯 左㒋二於テッS 字窑ノ前線線下滕部二於デ稍く明 瞭キ缺ク。

第3渔 $\mathrm{EZ}$. 第15例 우 14 筬。

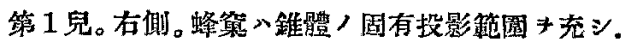

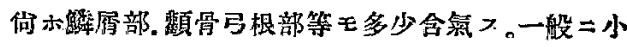

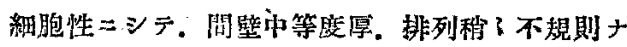

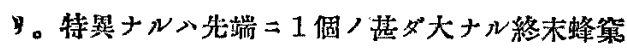

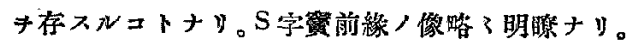

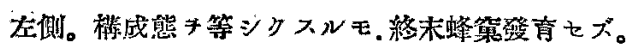

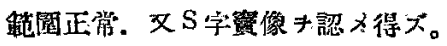

第 2 兒。右側八第 1 兒八右側二. 左側八第 1 兄 左側二程メテ酷似 致不。

第4圖 $\mathrm{F}, Z$ ：第 23 例 우우 18 啙。

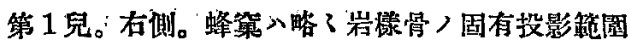
キ充ス。小細胞性ニシデ、間壁中等度厚ナルモ。
排列概ネ正規ナリ。非含氮部ハ板障性コシテ．合

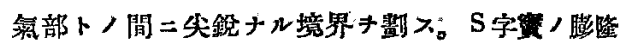
中等度。左側; 孚嘴突起心一核二板障性骨 $ョ \mathfrak{y}$

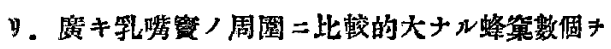

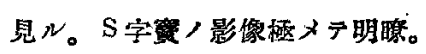

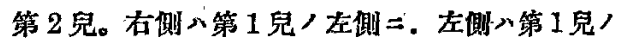

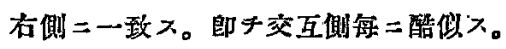

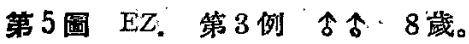

第 1 見. 第 2 兄共蜂笨入發有著シク不良ニシテ.

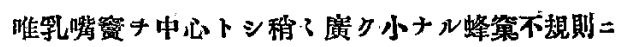

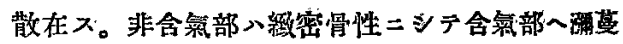

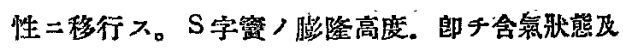

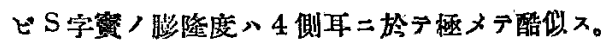
第6 圖 $\mathrm{EZ}$. 第 25 例令令 23 啙。

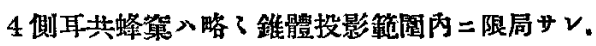
小蜂笨性ニシテ間壁肥厚シ. 排列統一キ缺ク。S

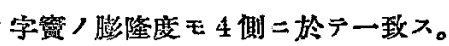

第7圖 $\mathrm{ZZ}$ 、第 13 例令今 15 瓷。 第 1 罗及ビ第 2 見共蜂策ノ登育度及ビ間壁ノ狀悬 一致スルモ前粕入中細胞性ニシテ. 排列正規ナN 二反シ後者 ハ小細胞性ニシテ排列不規則ナリ。

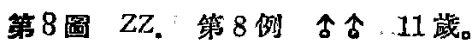

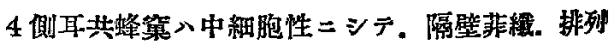
規則正シキモ。第1罗ノ登育度ふ極メテ可良ナル 二反シ第 2兒ノ夫レハ正常域キ越へズ。

第 9 圖

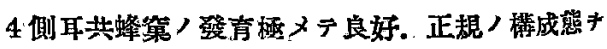

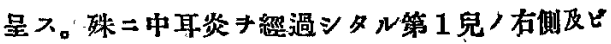
第 2 兒ノ左側二於テモ健側耳ト比慗シ含占狀㮩二 何等ノ善異キモ認ムル能ハス゚。

$$
\text { （原稿到青 }=\text { 昭和11 - } 6 \cdot 25 ）
$$




\section{岡 崎 論 文 附 圖 1}

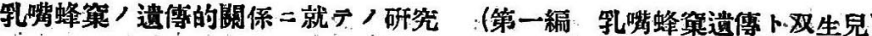

\section{第 1 圆}

，右、侧 左 側
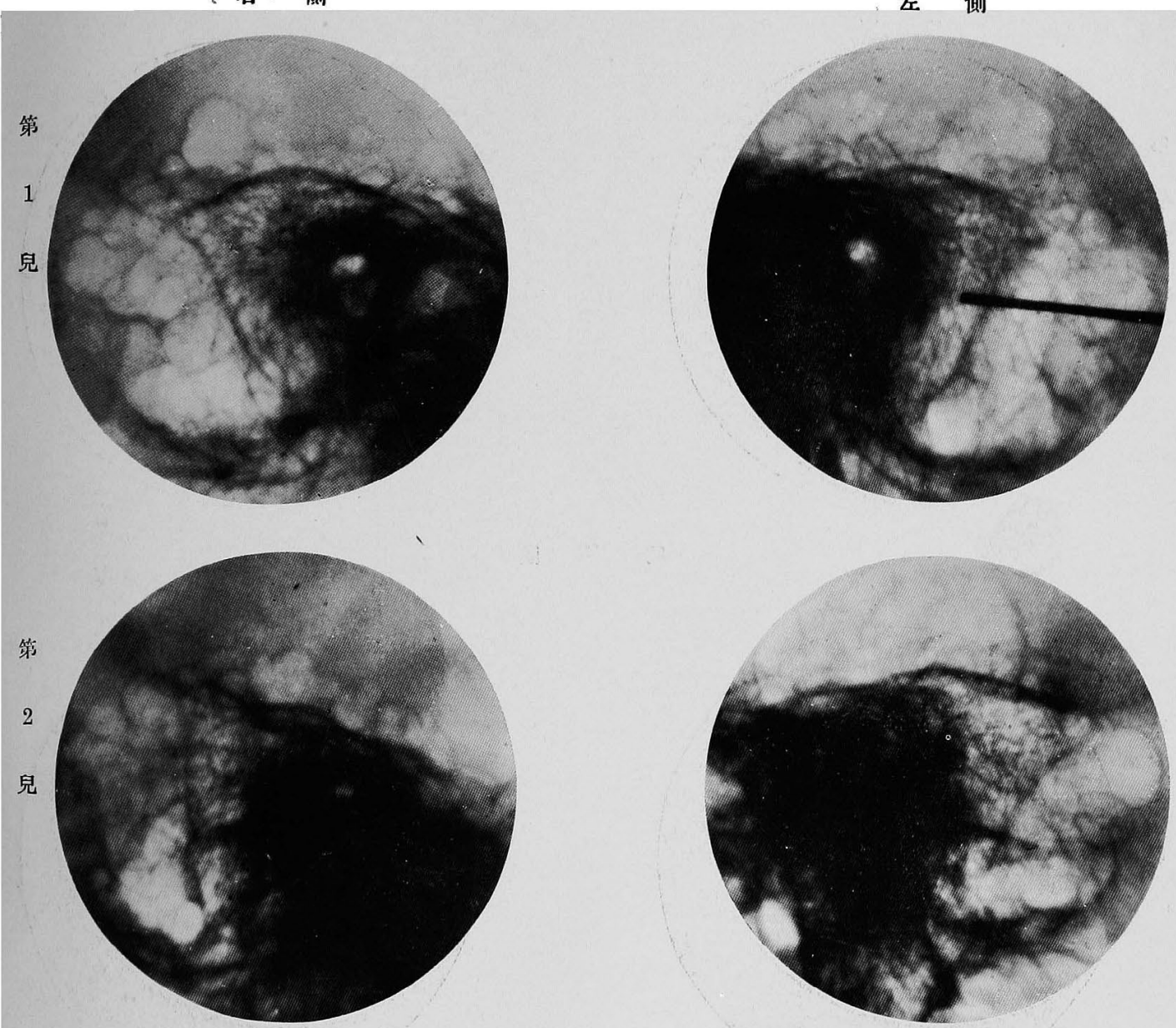

第

右 側

圖
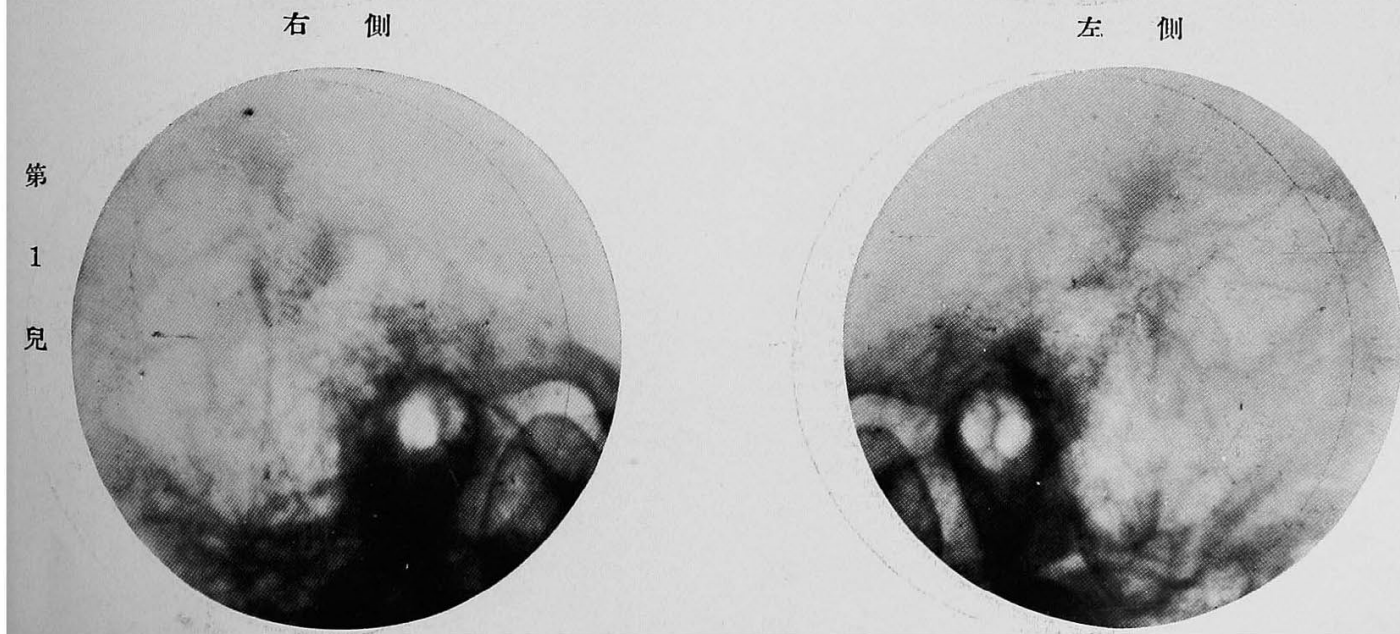

Morio Okasaki: Úber dic Bedeutung der Erufaktoren bei dẹr Pneumalisı der Warzenfortsaetze. (Erste Mitteilung: $Z$ willingsfors hung.) 
岡 崎論文附圖 2

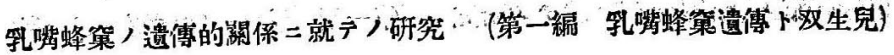

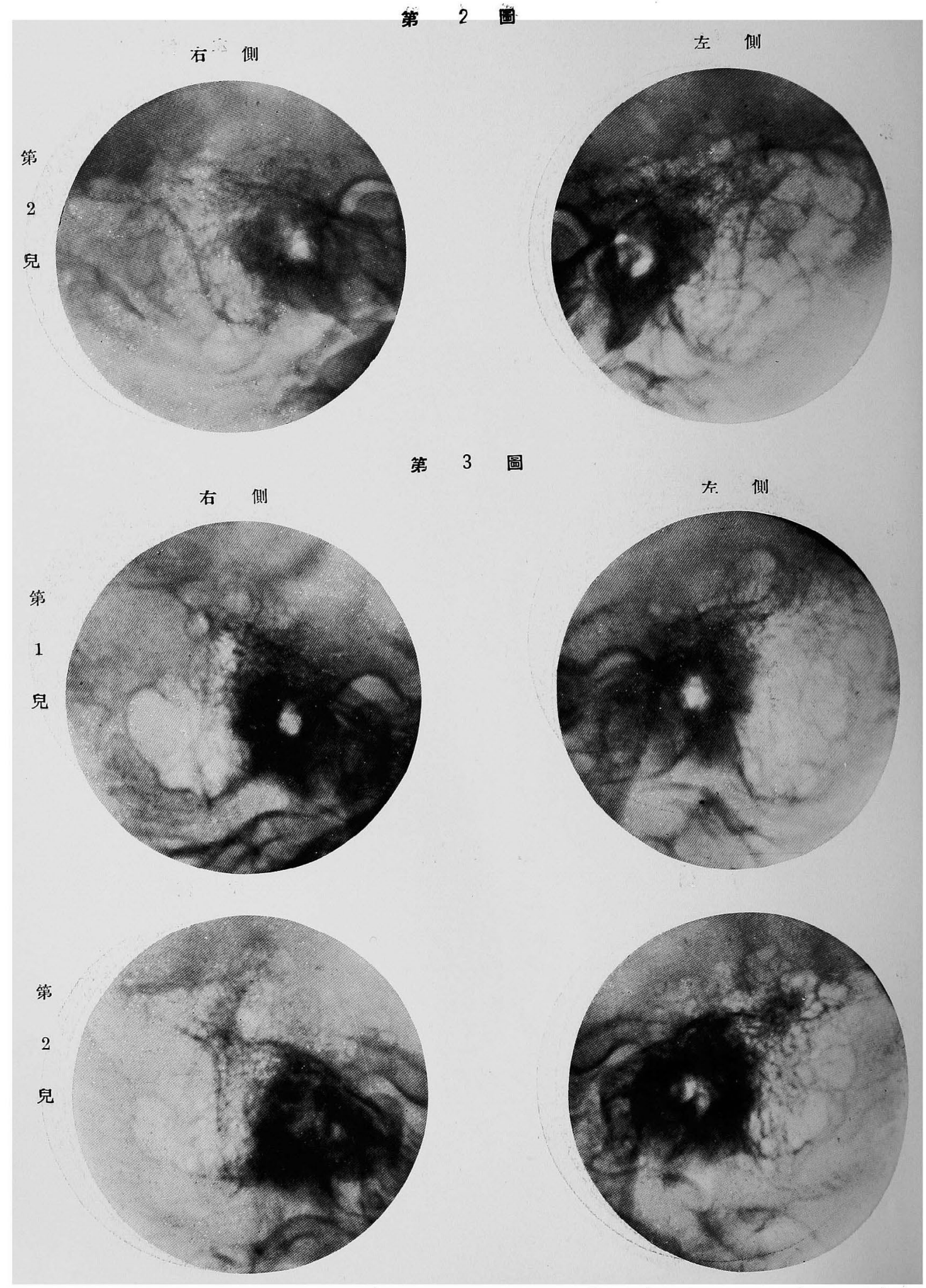

Morio Okaśaki: Über die Bedeutung der Erbfaktoren bei dér Pneumatisa der

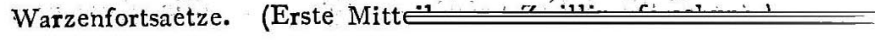




\section{岡 崎論文，附圖 3}

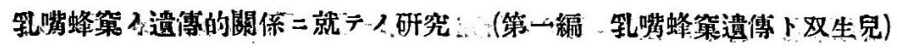

第 4 圖

喵会右
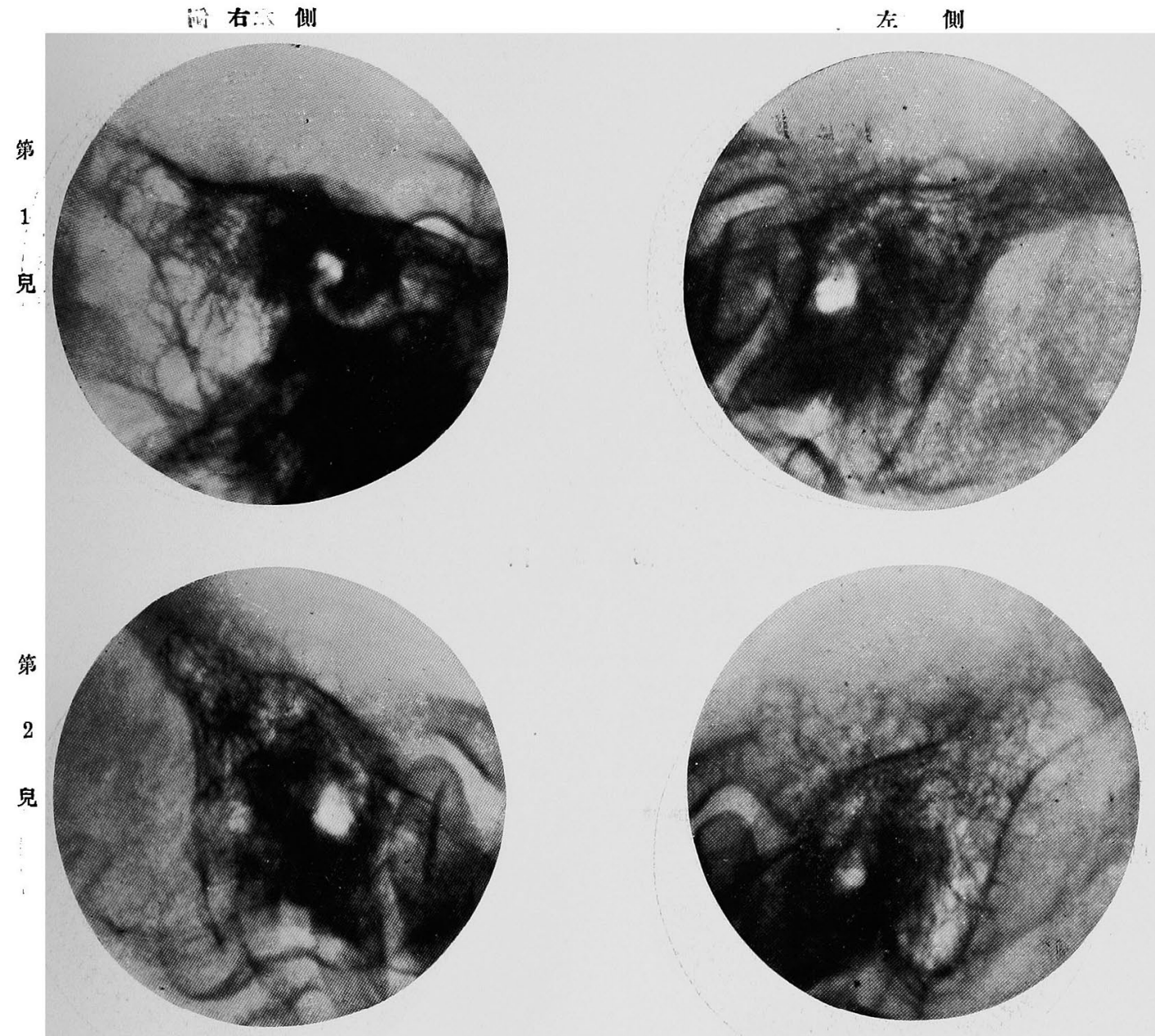

第 5 圖
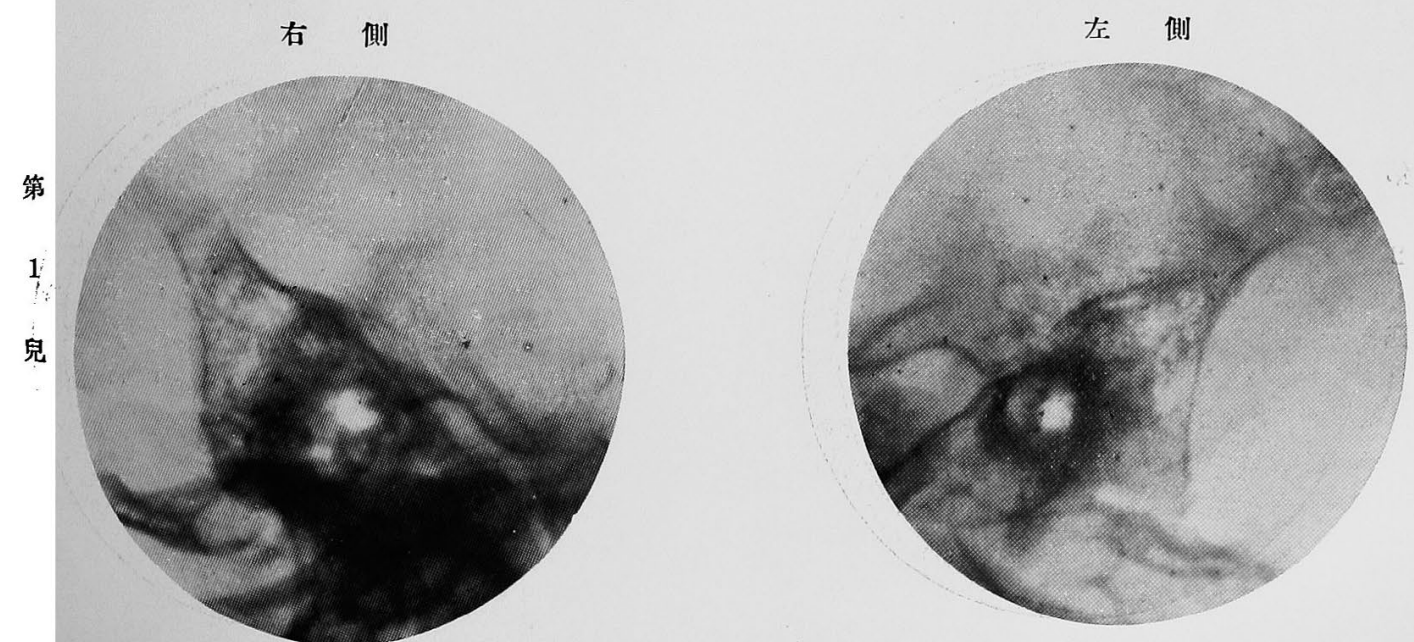

Morí Okasaki: Ưber die Bedeutung der Erbfaktoren bei dér Pneumatisa der Warzenfortsaetze. (Erste Mitteilung: $Z$ willingsforschung.) 


\section{岡 崎、論 文 附 圖 4}

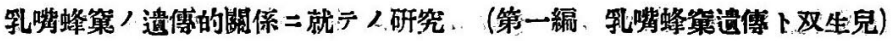

第 5 圆
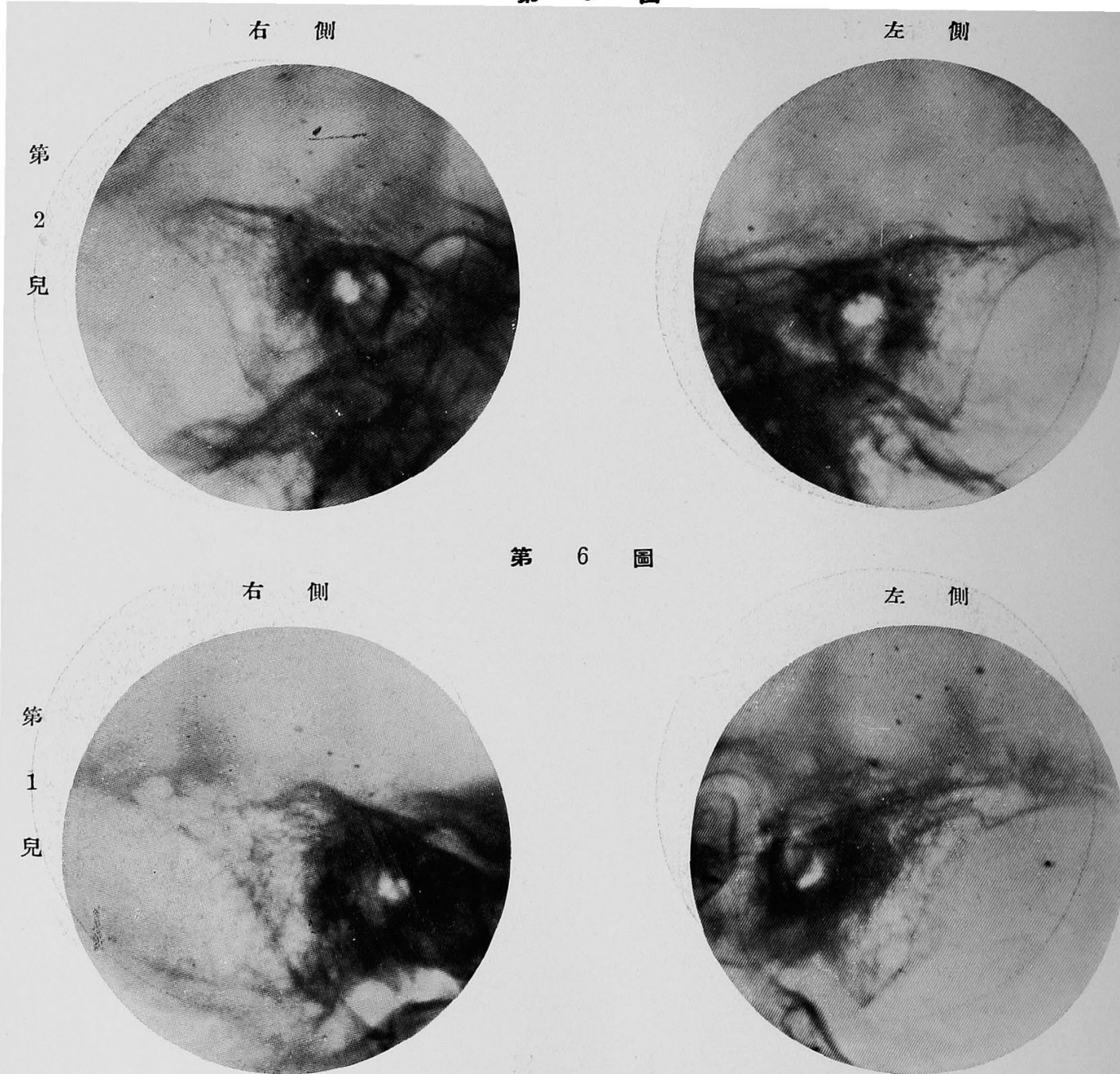

第 6 圖

\section{圖}
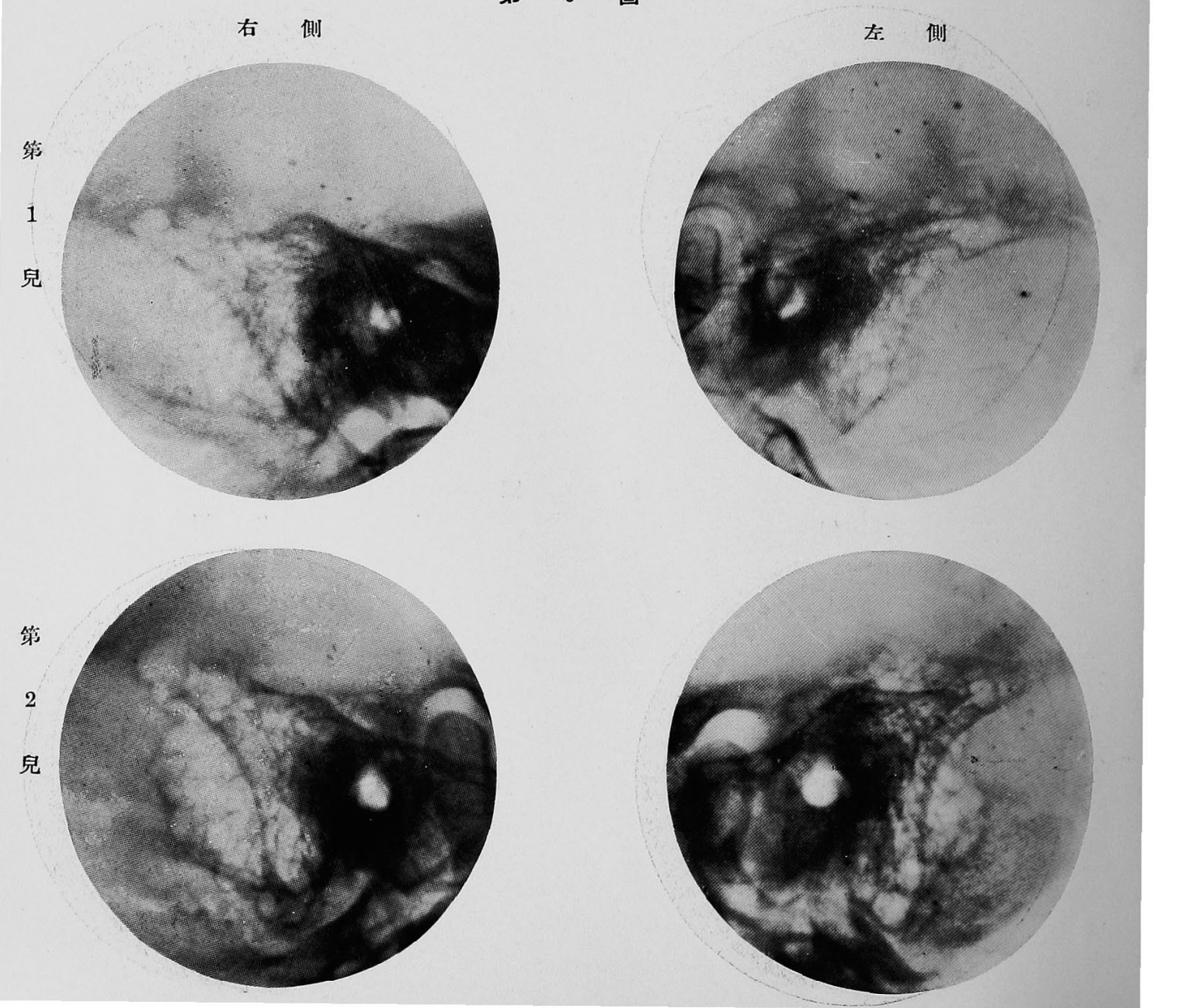

Morio Okasaki: Über die Bedeutung der Erbfaktoren bei, der Pneumatișa der Warzenfortsaetze. (Erste Mitteil...... 7willinmeforcehuna.A 


\section{网 崎 論 文 附 圖 5}

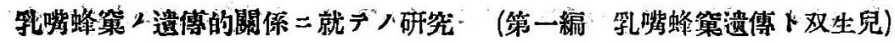

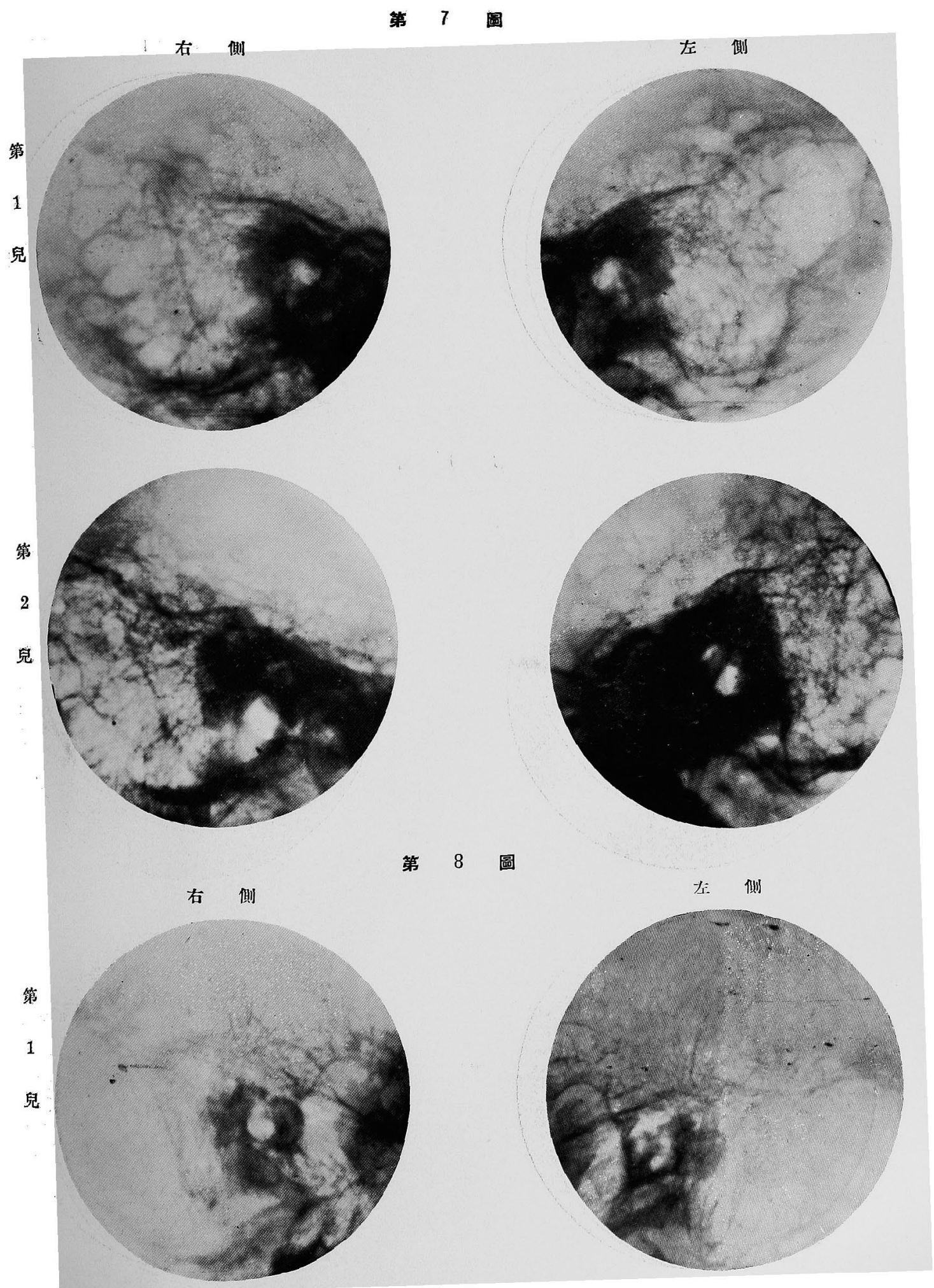

Morko okadak: Über die Bedeutung der Erbfaktoren bei der Pneumatisa der Warzenfortsaetzc. (Exste Mitteilung : Zwillingsforschung.) 


\section{岡·崎 論 文 附圖 6}

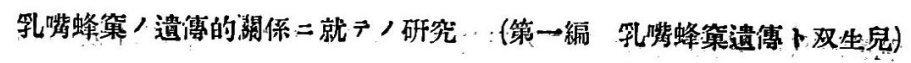

第 8 圖
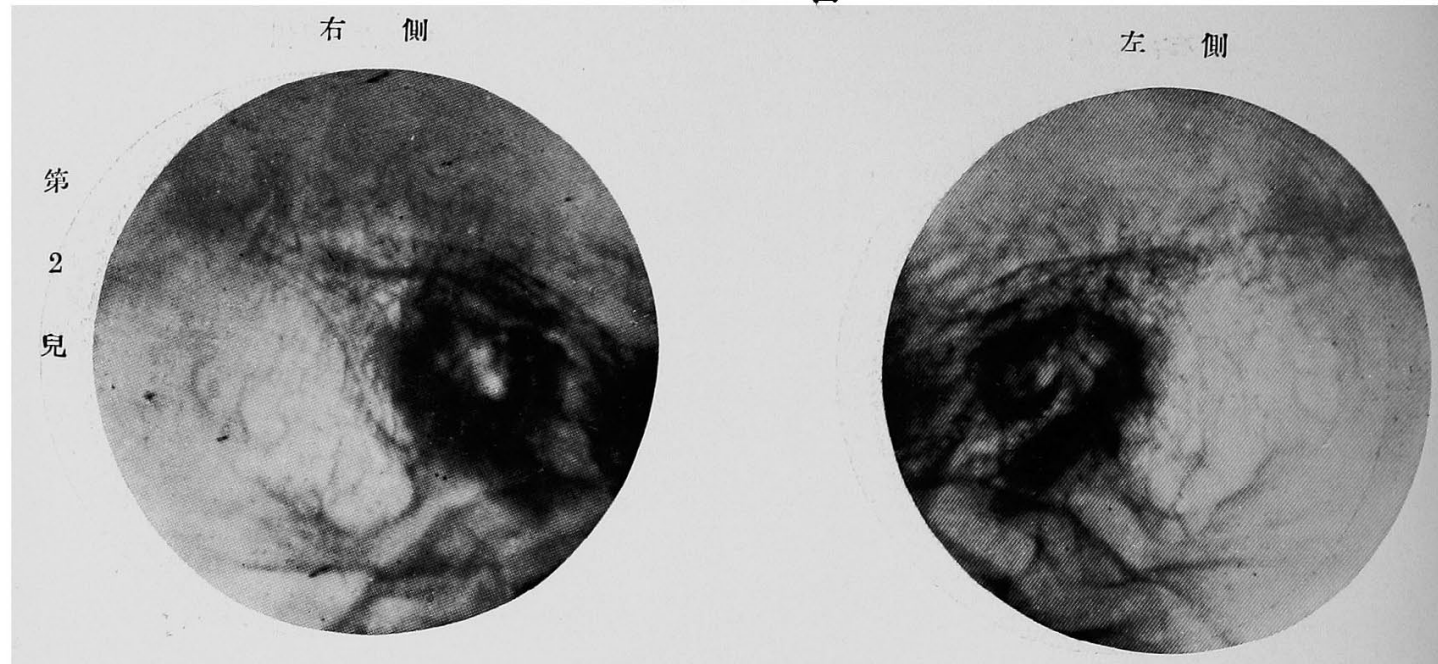

第 9 圖

在 侧
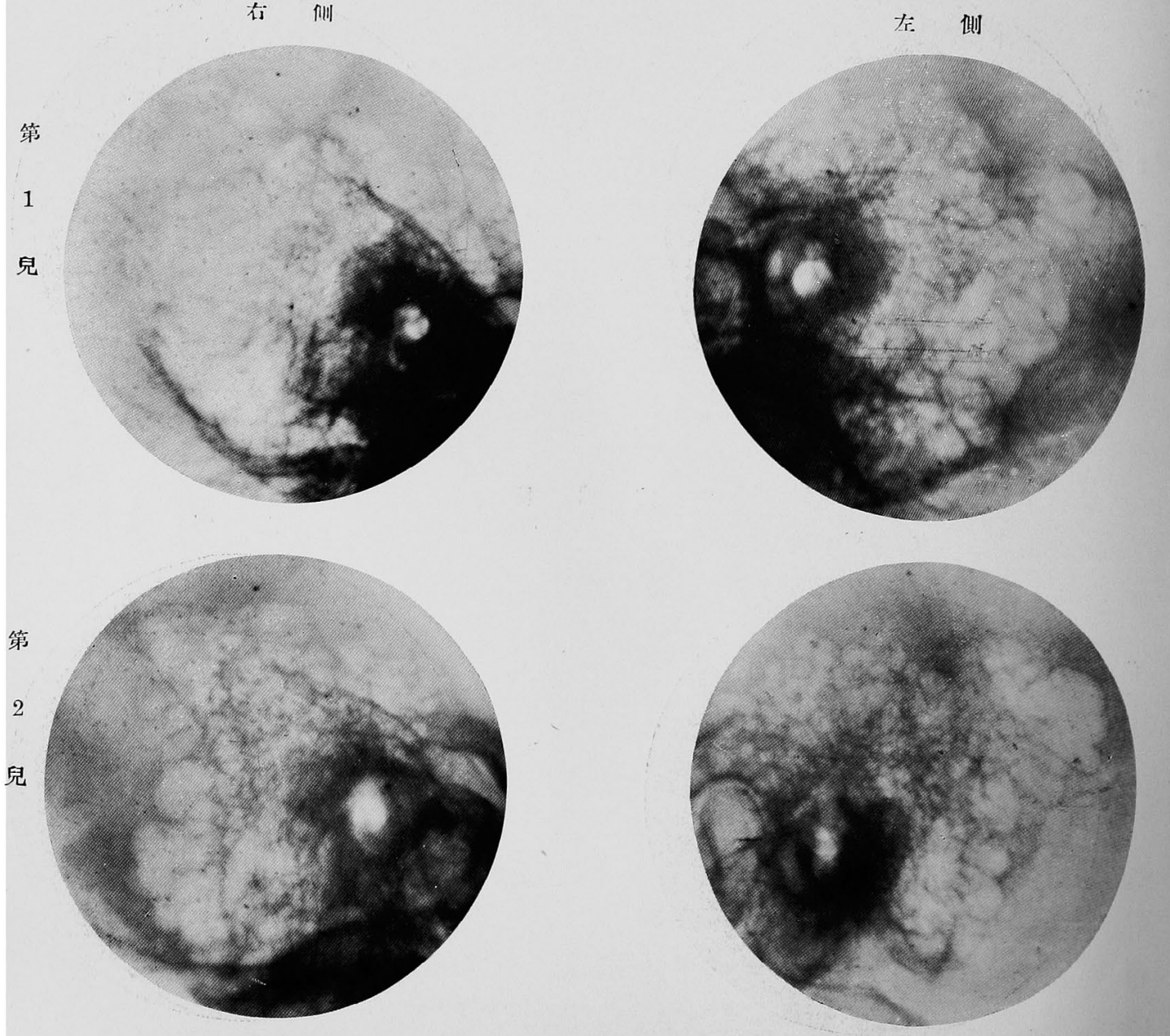

Morio Okasaki: Über die Bedeutung der Erbfaktoren bei der Pneumątisa der Warzenfortsaetze, (Erste Mitteiluna: Zwillinosforschung.) 